\title{
ANNUAL REPORT ON MIGRATION AND ASYLUM 2019: IRELAND \\ ANNE SHERIDAN
}

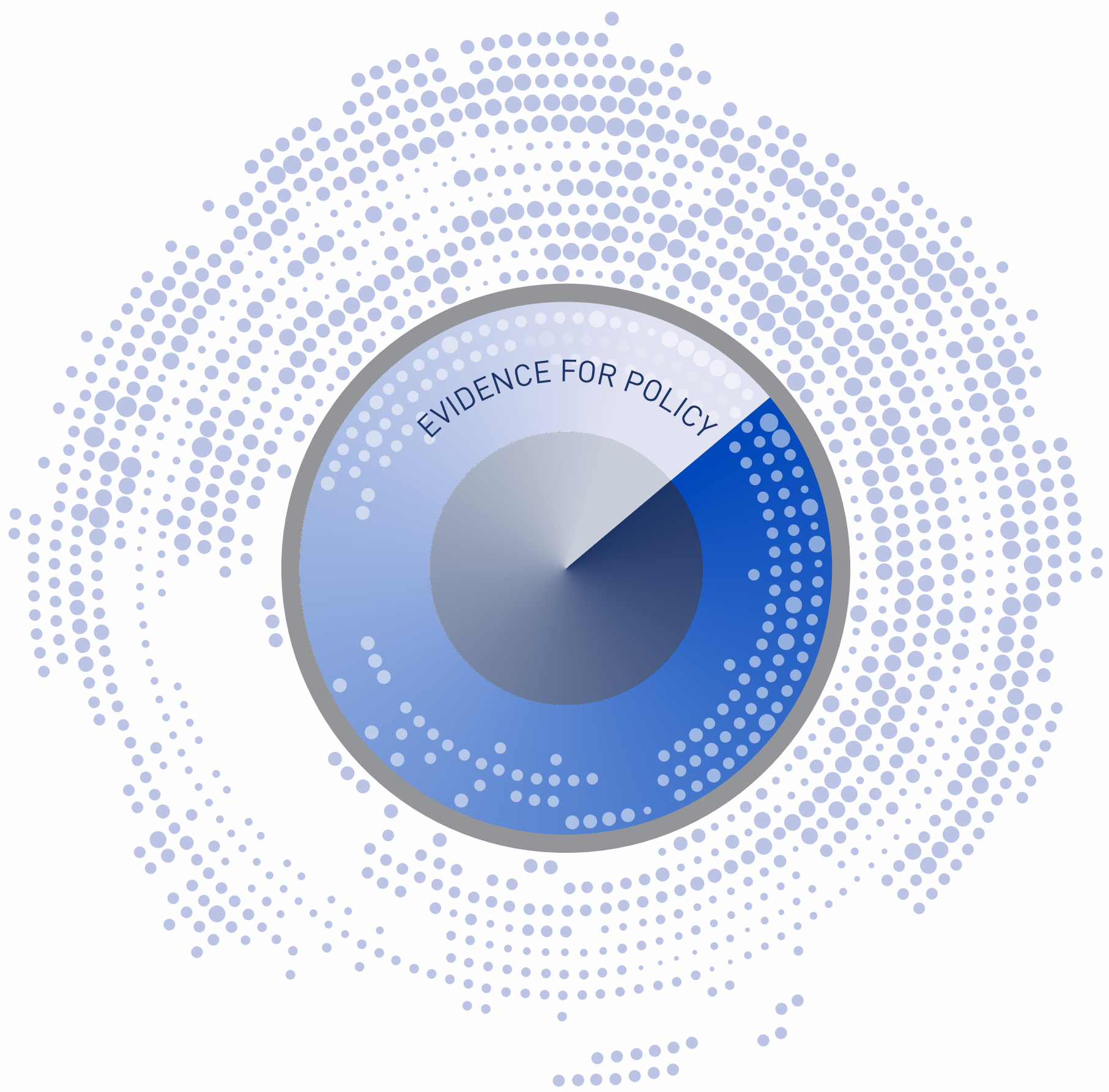

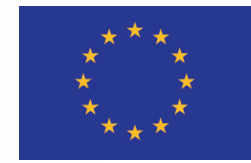

EMN Ireland is funded by 


\section{ANNUAL REPORT ON MIGRATION AND ASYLUM 2019: IRELAND}

Anne Sheridan

December 2020

\section{SURVEY AND STATISTICAL REPORT SERIES}

\section{NUMBER 102}

Study completed by the Irish National Contact Point of the European Migration Network (EMN) which is financially supported by the European Union and the Irish Department of Justice. The EMN has been established via Council Decision 2008/381/EC.

Available to download from www.emn.ie

(C) The Economic and Social Research Institute

Whitaker Square, Sir John Rogerson's Quay, Dublin 2

DOI https://doi.org/10.26504/sustat102

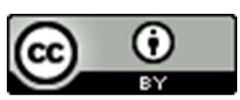

This Open Access work is licensed under a Creative Commons Attribution 4.0 International License (https://creativecommons.org/licenses/by/4.0/), which permits unrestricted use, distribution, and reproduction in any medium, provided the original work is properly credited. 


\section{THE EUROPEAN MIGRATION NETWORK}

The aim of the European Migration Network (EMN) is to provide up-to-date, objective, reliable and comparable information on migration and asylum at Member State and EU levels with a view to supporting policymaking and informing the general public. The Irish National Contact Point of the European Migration Network, EMN Ireland, sits within the Economic and Social Research Institute (ESRI).

\section{ABOUT THE ESRI}

The mission of the Economic and Social Research Institute is to advance evidencebased policymaking that supports economic sustainability and social progress in Ireland. ESRI researchers apply the highest standards of academic excellence to challenges facing policymakers, focusing on 12 areas of critical importance to 21stcentury Ireland.

The Institute was founded in 1960 by a group of senior civil servants led by Dr T.K. Whitaker, who identified the need for independent and in-depth research analysis to provide a robust evidence base for policymaking in Ireland.

Since then, the Institute has remained committed to independent research and its work is free of any expressed ideology or political position. The Institute publishes all research reaching the appropriate academic standard, irrespective of its findings or who funds the research.

The quality of its research output is guaranteed by a rigorous peer review process. ESRI researchers are experts in their fields and are committed to producing work that meets the highest academic standards and practices.

The work of the Institute is disseminated widely in books, journal articles and reports. ESRI publications are available to download, free of charge, from its website. Additionally, ESRI staff communicate research findings at regular conferences and seminars.

The ESRI is a company limited by guarantee, answerable to its members and governed by a Council, comprising 14 members who represent a cross-section of ESRI members from academia, civil services, state agencies, businesses and civil society. The Institute receives an annual grant-in-aid from the Department of Public Expenditure and Reform to support the scientific and public interest elements of the Institute's activities; the grant accounted for an average of 30 per cent of the Institute's income over the lifetime of the last Research Strategy. The remaining funding comes from research programmes supported by government departments and agencies, public bodies and competitive research programmes.

Further information is available at www.esri.ie 


\section{THE AUTHOR}

Anne Sheridan is Senior Policy Officer at the Irish National Contact Point of the European Migration Network (EMN), within the Economic and Social Research Institute (ESRI).

\section{ACKNOWLEDGEMENTS}

This report has benefited greatly from comments and input by staff members of the International Protection Office (IPO); Chairperson, Registrar and staff members of the International Protection Appeals Tribunal (IPAT); Thomas Dunning of Tusla, the Child and Family Agency; Charlene Sadik and Bríd O'Loughlin of the International Organization for Migration (IOM) Ireland; staff members of the Department of Business, Enterprise and Innovation; staff members of the Department of Justice; staff members of the Department of Children, Equality, Disability, Integration and Youth (DCEDIY); Edel McGinley of the Migrant Rights Centre of Ireland (MRCI); Fiona Finn of Nasc; and Enda O'Neill and Maria Hennessy of UNHCR Ireland.

I would also like to acknowledge the comments and assistance of my colleagues Emma Quinn, Evie McCullough and Sarah Burns.

Assistance with analysis of significant legal occurrences during 2019 including case law summaries was provided by Patricia Brazil LLB, MLitt, PhD (DUB), Barrister-atLaw, EMN legal consultant.

This European Migration Network Study, compiled according to commonly agreed specifications, provides a coherent overview of migration, asylum trends and policy developments for 2019. The report consists of information gathered primarily for the EU-level synthesis report of the EMN, Annual Report on Migration and Asylum 2019. All reports are available at: http://ec.europa.eu/dgs/home-affairs/what-wedo/networks/european_migration_network/index_en.htm

This report has been accepted for publication by the Institute, which does not itself take institutional policy positions. The report has been peer reviewed prior to publication. The author is solely responsible for the content and the views expressed do not represent the position of the Economic and Social Research Institute, the Department of Justice, or the European Commission, DirectorateGeneral Migration and Home Affairs. 



\section{TABLE OF CONTENTS}

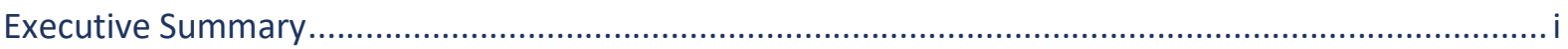

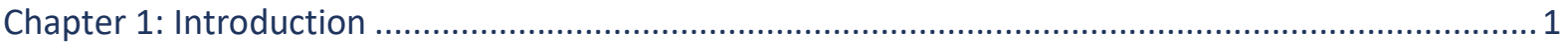

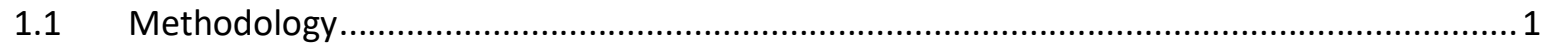

1.2 Structure of migration and asylum policy..............................................................

1.2.1 Structure of the immigration system .......................................................... 5

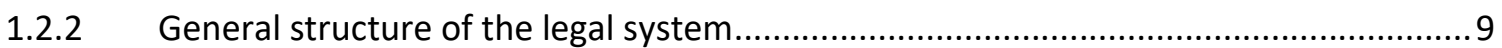

Chapter 2: Political and international developments and statistical context..................................13

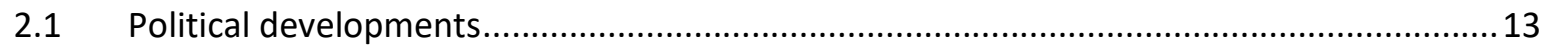

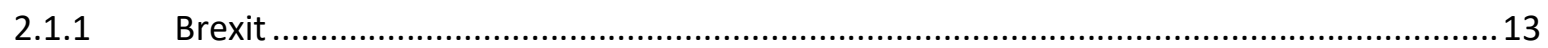

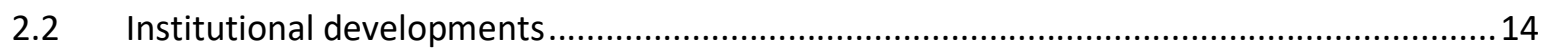

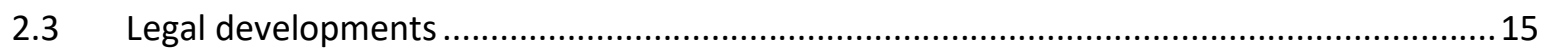

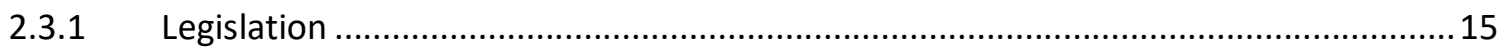

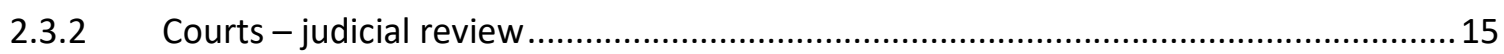

2.4 United Nations and other international developments ........................................... 17

2.4.1 Convention on the Elimination of all Forms of Racial Discrimination ........................17

2.4.2 Visit of UN High Commissioner for Refugees to Ireland ..........................................2 21

2.4.3 Global Refugee Forum, Geneva, December 2019............................................21

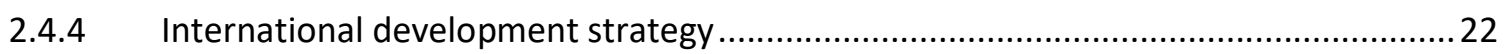

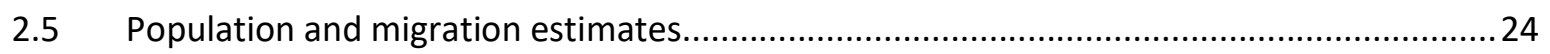

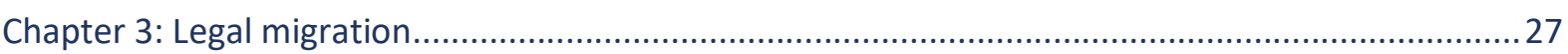

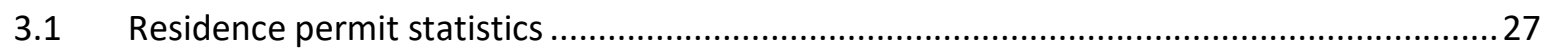

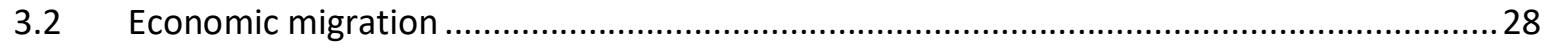

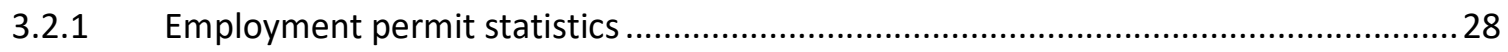

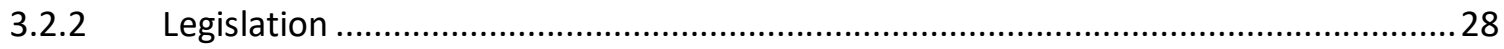

3.2.3 General Scheme of an Employment Permits (Consolidation and Amendment) Bill.....30

3.2.4 Changes to immigration arrangements for spouses and de facto partners of Critical

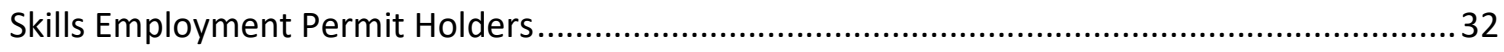

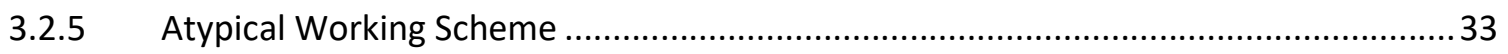

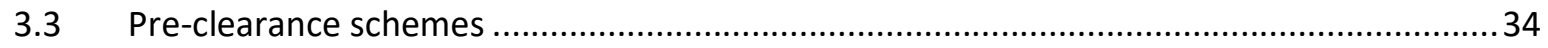

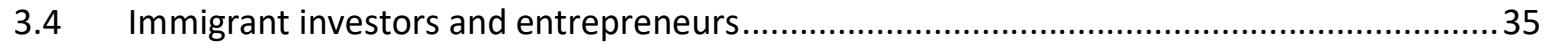

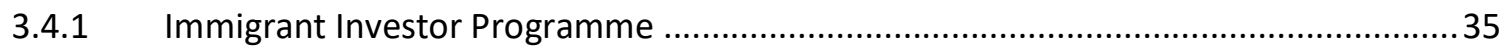

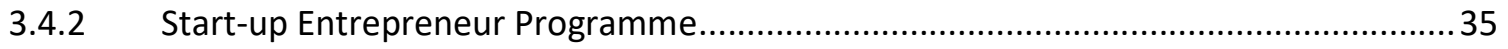

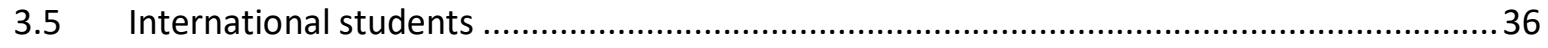




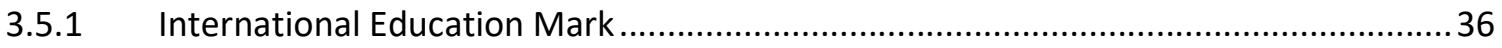

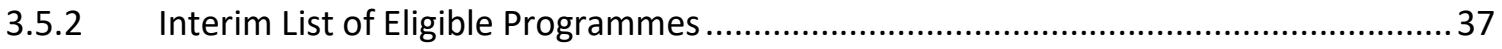

3.5.3 Online immigration registration renewal system for students...................................37

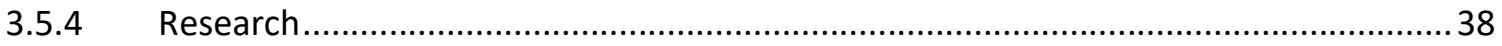

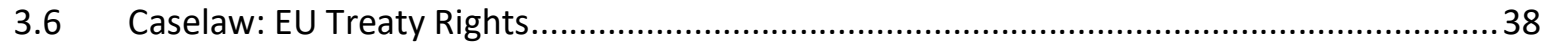

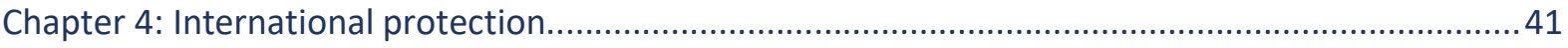

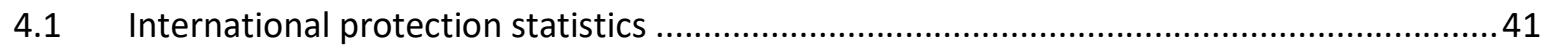

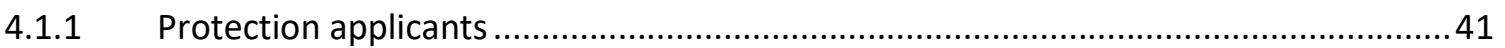

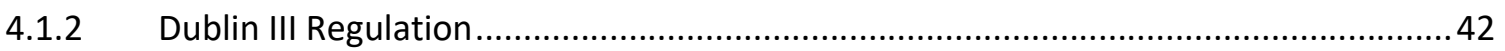

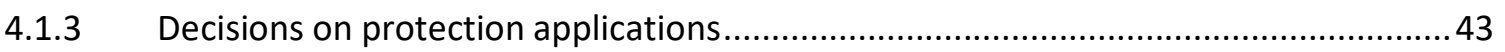

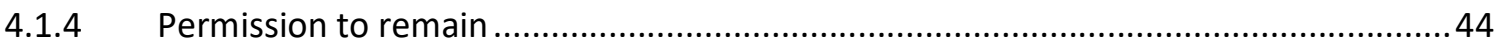

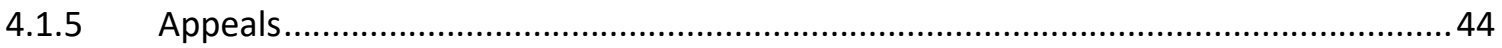

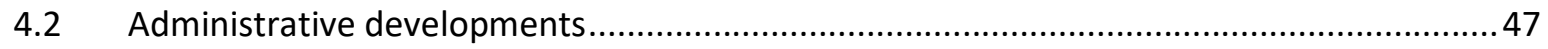

4.2.1 Processing times for international protection applications...................................... 47

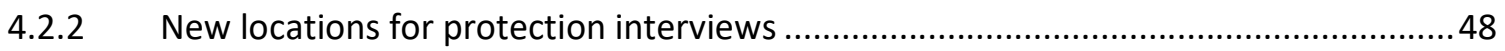

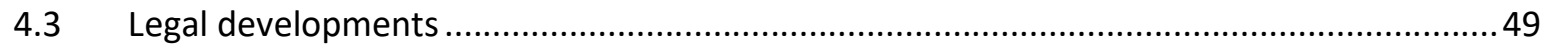

4.3.1 Judicial review in relation to Tribunal decisions ......................................................... 49

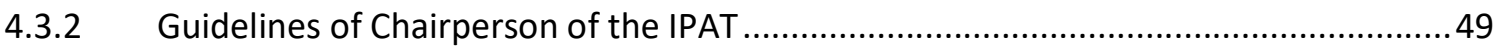

4.3.3 Preliminary reference to Court of Justice of the European Union (CJEU) ....................50

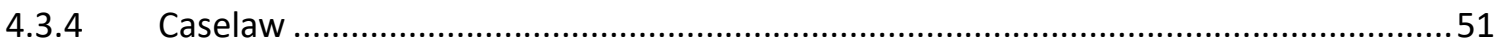

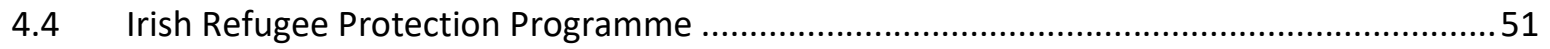

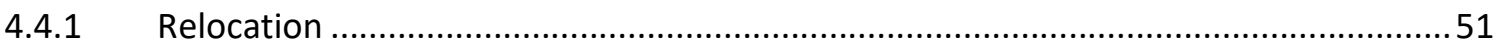

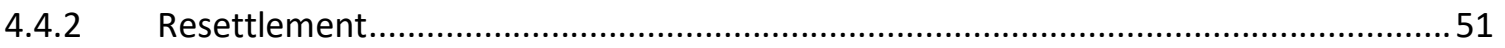

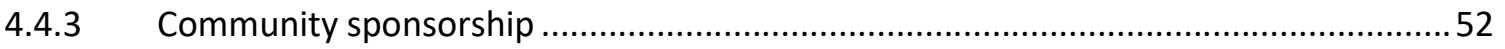

4.4.4 Emergency Reception and Orientation Centres .......................................................... 54

4.4.5 Irish Humanitarian Assistance Programme...................................................................5 54

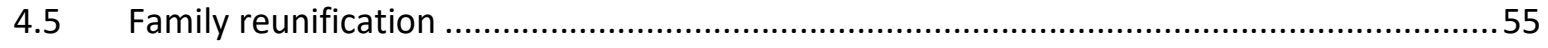

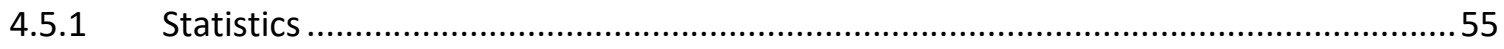

4.5.2 International Protection Act (Family Reunification) (Amendment) Bill 2017...............55

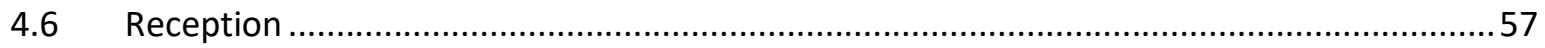

4.6.1 Right to work for international protection applicants ..............................................57

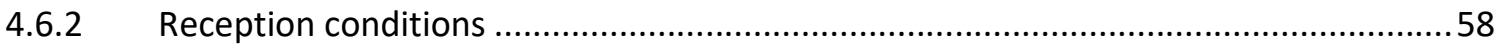

4.6.3 Joint Committee on Justice and Equality report on the direct provision system .........68

4.6.4 National Quality Standards for accommodation centres ............................................69

4.6.5 Spending review on direct provision system …...................................................... 70 
4.6.6 Establishment of expert group on direct provision system ...................................... 71

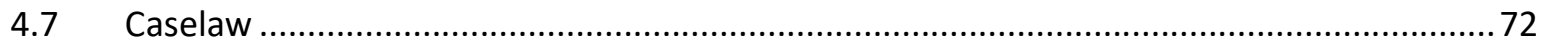

Chapter 5: Unaccompanied minors and other vulnerable groups .................................................79

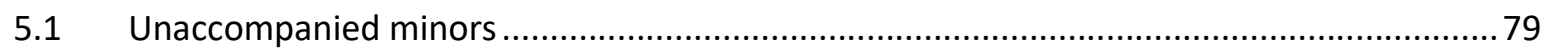

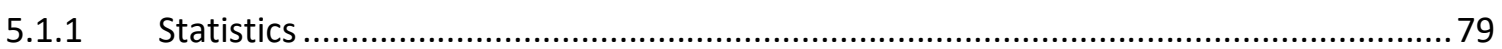

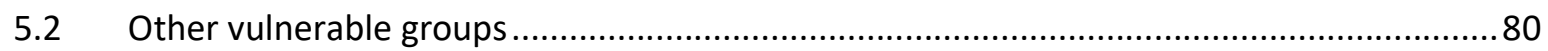

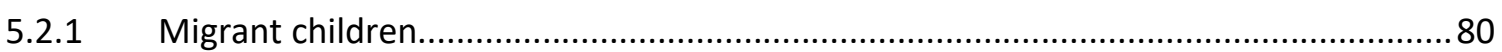

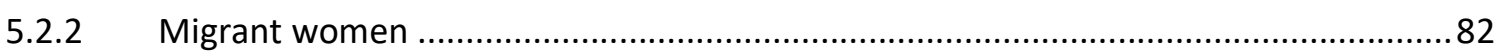

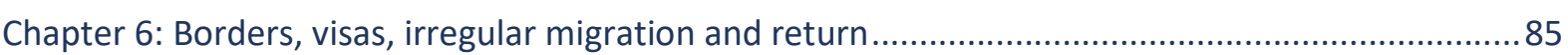

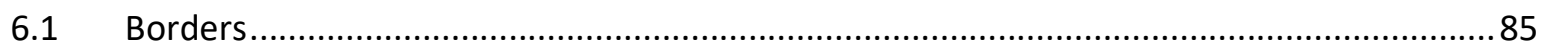

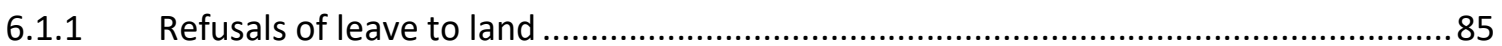

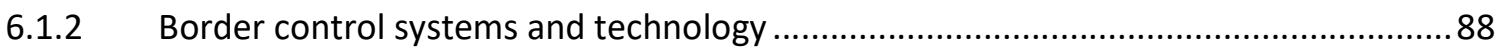

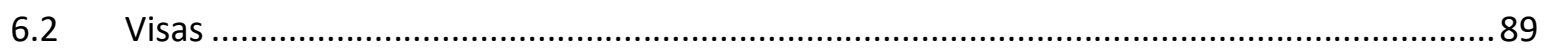

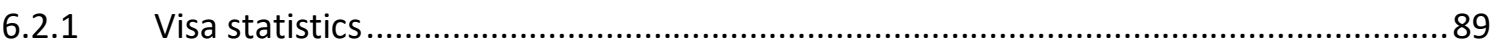

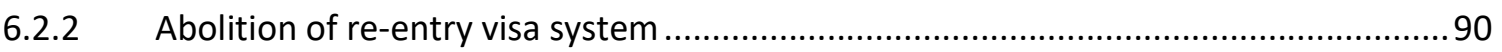

6.2.3 New five-year multi-entry tourist visa option for China nationals ..............................90

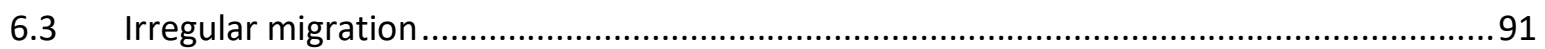

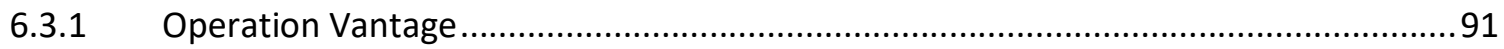

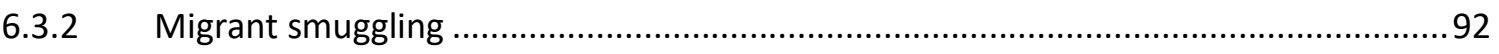

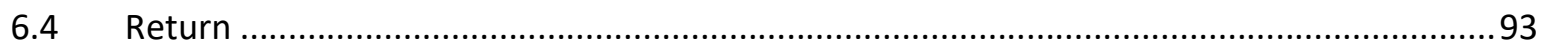

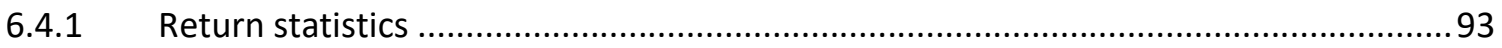

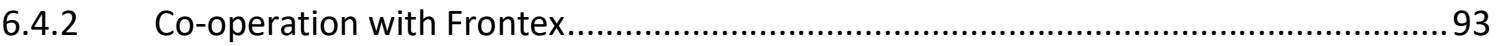

6.4.3 Amendment to the Immigration Act 1999 in relation to the prohibition on

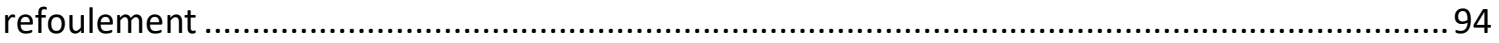

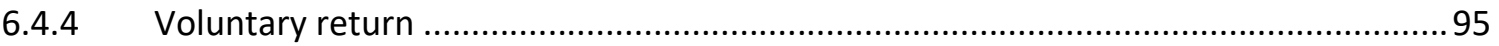

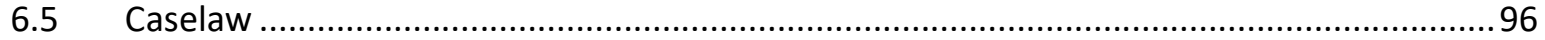

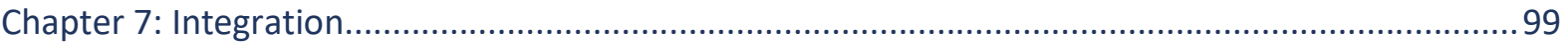

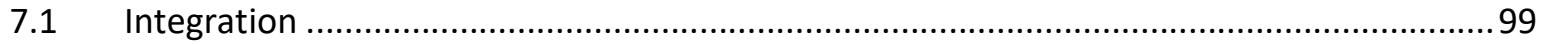

7.1.1 Mid-term review of Migrant Integration Strategy ...................................................99

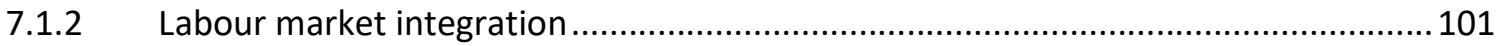

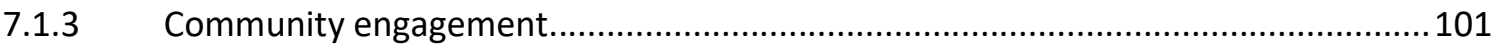

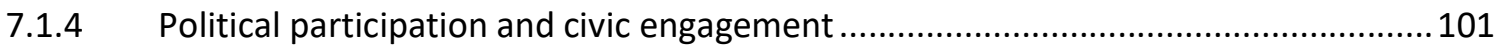

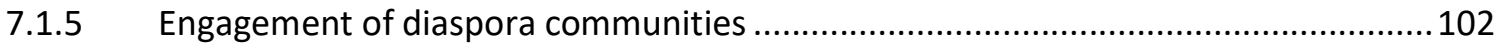

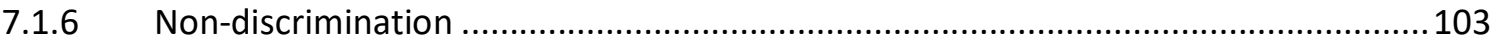

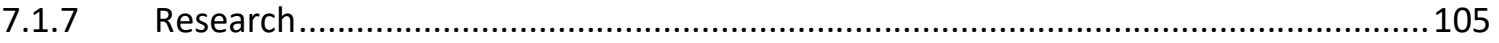




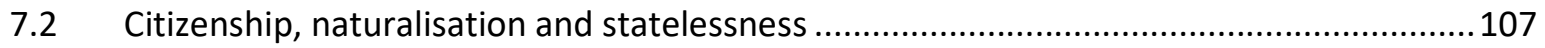

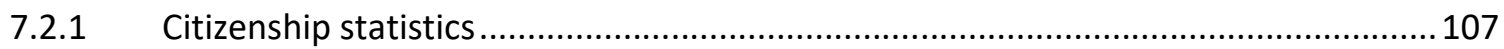

7.2.2 Legal challenge to concept of 'continuous residence' in relation to eligibility for

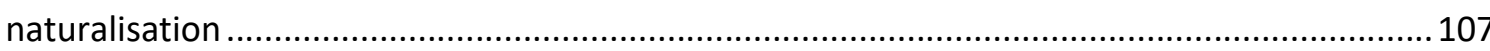

7.2.3 Irish Nationality and Citizenship (Restoration of Birthright Citizenship) Bill 2017 ....108

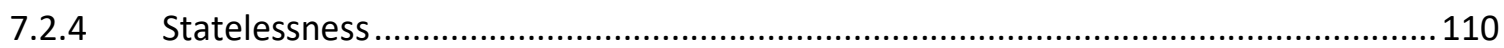

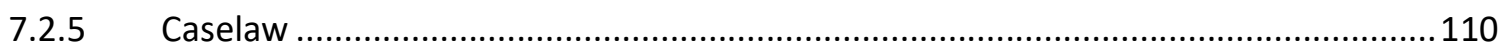

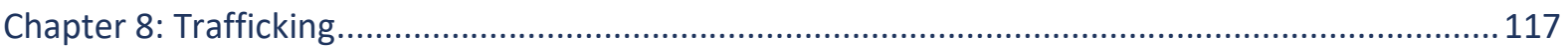

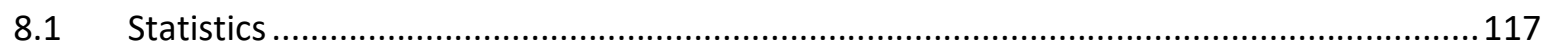

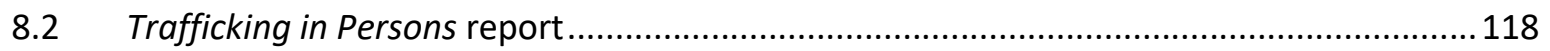

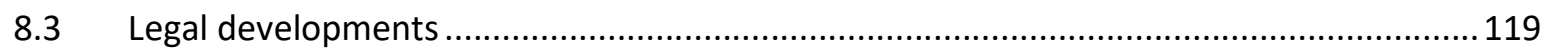

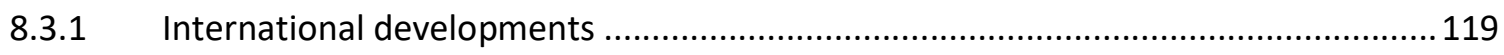

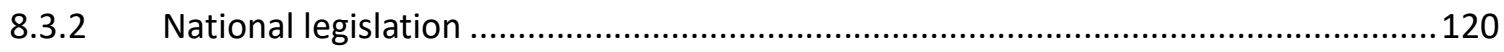

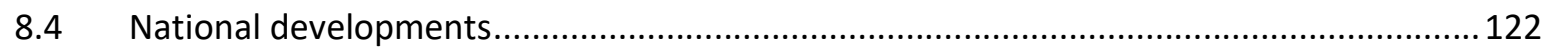

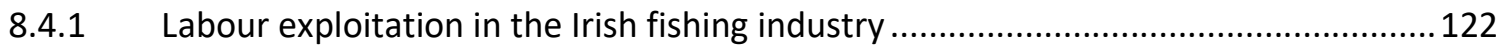

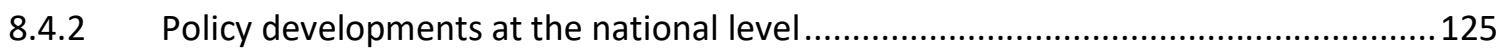

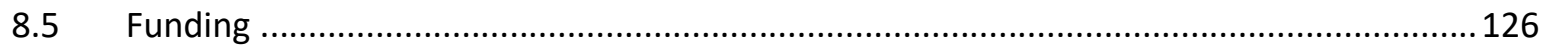

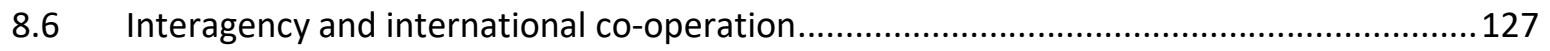

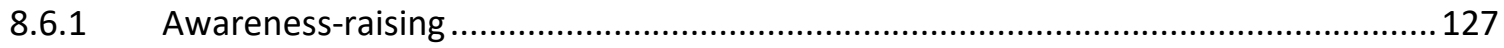

8.6.2 Co-operation by police and other operational authorities........................................128

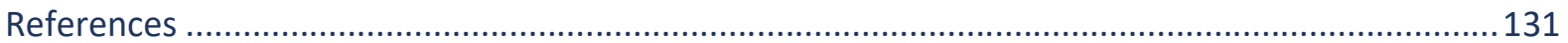




\section{LIST OF TABLES}

Table 3.1 All valid permits by reason in Ireland as of 31 December 2019 ....................................27

Table 3.2 First residence permits granted in Ireland and EU-28 Member States in 2019 ..............27

Table 4.1 Share of total EU protection applications for top nationalities of protection applicants in

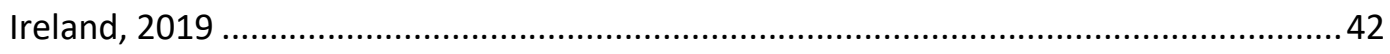

Table 4.2 Positive protection decisions at first instance and final decisions (rounded), Ireland 2019

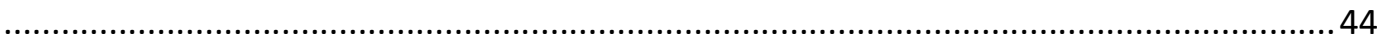

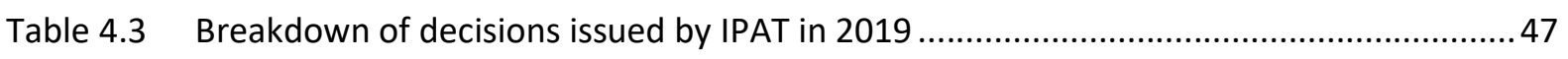

Table 6.1 Refusals of entry at external border in Ireland 2019................................................... 85

Table 6.2 Top nationalities for total voluntary return, 2019 ......................................................95

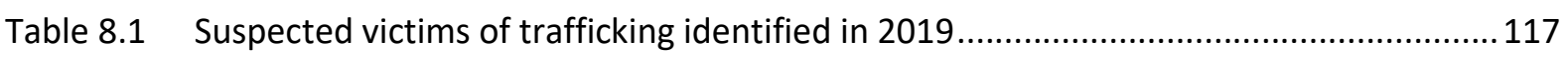

\section{LIST OF FIGURES}

Figure 1.1 Institutions in Ireland with responsibility for asylum and immigration 2019............... 4

Figure 2.1 Gross and net migration, Ireland, 2010-April 2020...............................................24

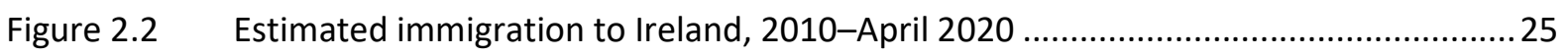

Figure 2.3 Estimated emigration from Ireland, 2010-April 2020 .............................................26

Figure 4.1 Top nationalities for international protection applications, 2019............................. 41

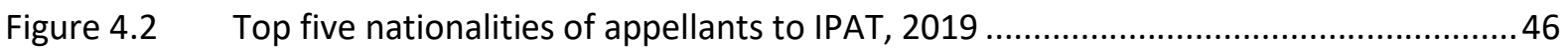


AIDA

AMIF

AOM

API

AWS

BIP

BIVS

BMU

CERD

CJEU

CRA

CSG

CSO

CSOL

CTA

Dáil

DBEI

DCEDIY

DEASP

DJE

DoJ

DPP

EASO

ECHR

ECRE
Asylum Information Database

Asylum, Migration and Integration Fund

aged-out minor

Advanced Passenger Information

Atypical Working Scheme

Beneficiary of International Protection

British Irish Visa Scheme

Border Management Unit

UN Convention on the Elimination of all Forms of Racial

Discrimination

Court of Justice of the European Union

Children's Rights Alliance

Community Sponsorship Group

Central Statistics Office

Critical Skills Occupations List

Common Travel Area

Parliament, lower house

Department of Business, Enterprise and Innovation

Department of Children, Equality, Disability, Integration and Youth

Department of Employment Affairs and Social Protection

Department of Justice and Equality

Department of Justice

Director of Public Prosecutions

European Asylum Support Office

European Convention on Human Rights

European Council on Refugees and Exiles 


\begin{tabular}{|c|c|}
\hline ECtHR & European Court of Human Rights \\
\hline EEA & European Economic Area \\
\hline EMN & European Migration Network \\
\hline EMPACT & European Multidisciplinary Platform Against Criminal Threats \\
\hline ENAR Ireland & European Network Against Racism Ireland \\
\hline EROC & Emergency Reception and Orientation Centre \\
\hline EU & European Union \\
\hline Garda Síochána & National police force \\
\hline GNI & Gross National Income \\
\hline GNIB & Garda National Immigration Bureau \\
\hline GNPSB & Garda National Protective Services Bureau \\
\hline GOSHH & Gender, Orientation, Sexual Health and HIV \\
\hline GRETA & Group of Experts Against Trafficking in Human Beings \\
\hline HPSU & high-potential start-up \\
\hline HSE & Health Service Executive \\
\hline HSEOL & Highly Skilled Eligible Occupations List \\
\hline HTEPII & Human Trafficking and Exploitation Project in Ireland \\
\hline HTICU & Human Trafficking Investigation and Co-ordination Unit \\
\hline ICEL & Ineligible Categories of Employment List \\
\hline $\mathrm{ICl}$ & Immigrant Council of Ireland \\
\hline ICN & International Council of Nurses \\
\hline ICT & Intra-Company Transfer \\
\hline IDG & Interdepartmental Group \\
\hline IEM & International Education Mark \\
\hline IGEES & Irish Government Economic and Evaluation Service \\
\hline IHAP & Irish Humanitarian Assistance Programme \\
\hline IHREC & Irish Human Rights and Equality Commission \\
\hline
\end{tabular}


Immigrant Investor Programme

Interim List of Eligible Programmes

ILO

International Labour Organization

INAR

Irish Network Against Racism

INIS

Irish Naturalisation and Immigration Service

$\mathrm{IOL}$

Ineligible Occupations List

IOM

International Organization for Migration

IPAS

International Protection Accommodation Services

IPAT

International Protection Appeals Tribunal

IPIU

Irish Passenger Information Unit

IPO

International Protection Office

IPPS

International Protection Procurement Services

IRC

Irish Refugee Council

IRMC

Irish Refugee and Migrant Coalition

IRPP

Irish Refugee Protection Programme

ISD

Immigration Service Delivery

ITWF

International Transport Workers' Federation

IVARRP

Irregular Voluntary Assisted Return and Reintegration Programme

JIT

joint investigation team

JRO

Joint Return Operation

JRS

Jesuit Refugee Service

$\mathrm{LAB}$

Legal Aid Board

LGBTI

Lesbian, Gay, Bisexual, Transgender, Intersex

LMNT

Labour Market Needs Test

MASI

Movement of Asylum Seekers in Ireland

MDU

Ministerial Decisions Unit

$\mathrm{MRCl}$

Migrant Rights Centre Ireland 


\begin{tabular}{|c|c|}
\hline Nasc & Refugee and Migrant Rights Centre \\
\hline NCP & National Contact Point \\
\hline NGO & non-governmental organisation \\
\hline NREMs & National Rapporteurs or Equivalent Mechanisms \\
\hline OCG & organised crime groups \\
\hline OCO & Ombudsman for Children Office \\
\hline ODA & Official Development Assistance \\
\hline Oireachtas & Parliament, both houses \\
\hline OPMI & Office for the Promotion of Migrant Integration \\
\hline ORAC & Office of the Refugee Applications Commissioner \\
\hline PPSN & Personal Public Service Number \\
\hline PSV & public service licence vehicle \\
\hline QQI & Quality and Qualifications Ireland \\
\hline RAT & Refugee Appeals Tribunal \\
\hline RDC & Refugee Documentation Centre \\
\hline RIA & Reception and Integration Agency \\
\hline RSA & Road Safety Authority \\
\hline SCSA & Separated Children Seeking Asylum \\
\hline Seanad & Parliament, upper house \\
\hline SGBV & sexual and gender-based violence \\
\hline STEP & Start-up Entrepreneur Programme \\
\hline Tánaiste & Deputy Prime Minister \\
\hline Taoiseach & Prime Minister \\
\hline TCN & third-country national \\
\hline TD & Teachta Dála (member of the Dáil) \\
\hline TEU & Treaty on European Union \\
\hline TFEU & Treaty on the Functioning of the European Union \\
\hline
\end{tabular}


THB

TIP

Tusla

UAM

UN

UNCAT

UNCRC

UNHCR

VARRP

VR

WLP

WRC
Trafficking in Human Beings

Trafficking in Persons (report)

Child and Family Agency

unaccompanied minor

United Nations

United Nations Convention Against Torture

United Nations Convention on the Rights of the Child

United Nations High Commissioner for Refugees

Voluntary Assisted Return and Reintegration Programme

voluntary return

Waterford Leadership Partnership

Workplace Relations Commission 


\section{EXECUTIVE SUMMARY}

The purpose of this report is to provide an overview of trends, policy developments and significant debates in the area of asylum and migration during 2019 in Ireland.

\section{STATISTICAL OVERVIEW}

According to Eurostat, some 168,297 residence permits were valid in Ireland as of 31 December 2019. This was an increase of 18.2 per cent over the total of 142,286 valid residence permits at the end of 2018. The top category for valid permits in Ireland was study, with 50,946 permits at the end of 2019.

The estimated population in the 12 months to April 2020 stood at 4.9774 million, an overall increase of 55,900 since April 2019. This was due to the combined natural increase in the population and net inward migration, which was 28,900 . Central Statistics Office (CSO) figures released in August 2020 estimate that the number of newly arrived immigrants decreased slightly year on year to 85,400 at end April 2020 from 88,600 at end April 2019. It should be noted that returning Irish nationals are included in these figures. Non-Irish nationals from outside the European Union (EU) accounted for 30,400 of total immigrants and were once again the largest immigrant group in the year to April 2020. Net inward migration for non-EU nationals is estimated at 19,000.

There was a small increase in returning Irish nationals from 26,900 to 28,900 . Outward migration of Irish nationals decreased slightly in the year to April 2020 $(28,300)$; its peak was 49,700 in 2012 . Net outward migration of Irish nationals in the year to April 2020 was minus 600 , less than the minus 2,900 in the year to April 2019.

A total of 137,207 visas, both long and short stay, were issued in 2019. The approval rate for visas was 89.5 per cent.

A total of 16,383 employment permits were issued during 2019, an increase of 22 per cent over the 2018 total of 13,398 . As in 2018, India was the top nationality, with 5,373 permits.

During 2019, a total of 3,347 applications were approved under the Atypical Working Scheme, which provides for short-term employment contracts in the 
State, due to the short-term nature of the contracts (i.e. between 15 and 90 days 1 ), which are not facilitated by the employment permit process.

According to rounded Eurostat figures, some 7,455 persons were refused entry at Ireland's borders in 2019, an increase of 55 per cent over the 4,795 refusals in 2018. The main nationalities of persons refused were Albania, Brazil, South Africa, Bolivia and Georgia. According to the Department of Justice, ${ }^{2}$ a total of 6,109 refusals of leave to land were recorded at Dublin Airport in 2019. A breakdown of first reasons for refusal under section 4(3) of the Immigration Act 2004 is provided in Chapter 6.

A total of 298 deportation orders were effected in 2019. Some 255 third-country nationals (TCNs) availed of voluntary return, 106 of whom were assisted by the International Organization for Migration (IOM).

Some 266 persons were granted permission to remain under section 49 of the International Protection Act 2015. An additional 169 persons were granted permission to remain at review stage.

The International Protection Office (IPO) received 4,781 applications for international protection in 2019, an increase of 30.2 per cent from the 3,673 applications received by the IPO in 2018. Ireland's applications accounted for 0.64 per cent of the total 745,255 applications made in the EU-28 countries in 2019.

The number of appeals received at the International Protection Appeals Tribunal (IPAT) remained stable in 2019. The IPAT received 2,043 appeals in 2019 in relation to international protection and the Dublin III Regulation, as opposed to 2,127 in 2018. In addition, 21 appeals were received under the Reception Conditions Regulations. It issued decisions in 1,944 cases, an increase of 78 per cent over the 1,092 in 2018.

Unaccompanied minors made 49 applications for international protection to the IPO in 2019. Some 17 applications had been made in 2018.

Some atypical permissions may be granted for periods greater than 90 days.

The Department of Justice and Equality changed name to Department of Justice with effect from 1 November 2020. Where comments or contributions to this report were received from November 2020, the Department is referred to as the Department of Justice. Where comments or contributions were received prior to November 2020, the Department is referred to as the Department of Justice and Equality. In addition, certain functions of the Department of Justice and Equality, in relation to integration, reception and the Irish Refugee Protection Programme, were transferred to the Department of Children, Equality, Disability, Integration and Youth from November 2020. 
A total of 14 applications were made by persons relocated to Ireland under the Search and Rescue operations in the Mediterranean in 2019.

The main nationalities of first instance applications for international protection in 2019 were Albania, Georgia, Zimbabwe, Nigeria and South Africa. Top countries of origin for appeals lodged were Pakistan, Zimbabwe, Albania, Nigeria and Bangladesh.

The IPO processed a total of 4,927 cases to completion in 2019 - this includes first instance recommendations in respect of international protection, decisions in respect of permission to remain, legacy subsidiary protection recommendations, Dublin decisions to transfer and decisions in respect of reviews of permission to remain. The median processing time in 2019 for full single procedure cases to first instance recommendation was 15.6 months.

The average time for the IPAT to process substantive international protection appeals, including 'transition' cases, in 2019 was approximately 170 days. However, for appeals that were both accepted and completed within the year 2019, the average processing time was 100 days.

According to Eurostat (rounded) figures, Ireland made a total of 1,870 first instance asylum decisions in 2019. Of the 975 positive decisions in 2019, there were 585 grants of refugee status, 120 grants of subsidiary protection status and 265 grants of humanitarian status. Some 895 negative decisions were reported.

A total of 184 referrals were made to the Social Working Team for Separated Children Seeking Asylum of Tusla, the Child and Family Agency, in 2019, up from the 129 referrals made in 2018.

In 2019, the Department of Justice and Equality received a total of 307 applications for family reunification under the International Protection Act 2015, in respect of 737 subjects. Some 254 subjects were approved; however, some of these may relate to applications made in previous years.

A total of 783 persons were resettled to Ireland during 2019. As at 31 December 2019, a total of 1,913 persons had been resettled over the duration of the Irish Refugee Protection Programme (IRPP). This left a balance of 72 persons under the resettlement strand of the IRPP to be resettled from Lebanon in early 2020. 
The second call for applications under the Irish Humanitarian Assistance Programme (IHAP) closed in February 2019. Some 192 beneficiaries arrived up to year end $2019 .^{3}$

Three citizenship ceremonies were held in 2019, on 29 April and 2 December in Killarney, and on 28 June in Waterford. Some 2,347 and 1,922 certificates of naturalisation were conferred at the two Killarney ceremonies respectively, while a total of 634 persons received certificates at the Waterford ceremony. These figures include both EU and non-EU nationals.

During 2019, a total of 42 suspected victims of trafficking were identified, a decrease from the 64 suspected victims of trafficking identified during 2018 . These figures include EU nationals.

\section{LEGISLATION}

Several legislative provisions of relevance to migration were introduced during 2019, including in relation to employment permits, trafficking, violence against women and domestic violence, return and Brexit. The Withdrawal of the United Kingdom from the European Union (Consequential Provisions) Act 2019 was signed into law by the President on 17 March 2019. Part 14 of this Act deals with certain immigration-related matters, including the provision of a legal basis for taking fingerprints of Irish visa and Irish transit visa applicants, to enable the continuance of the British-Irish Visa Scheme pursuant to Common Travel Area arrangements.

A list of legislation is included in Chapter 2 and legislation is explained under the relevant thematic headings throughout the Report.

\section{CASE LAW}

There were a number of significant cases related to migration and asylum during 2019, including in the areas of international protection, EU Treaty rights and citizenship and naturalisation. Case summaries are included under thematic headings throughout the Report.

Beneficiaries make their own travel arrangements to Ireland. The Department of Children, Equality, Disability, Integration and Youth, which took over these functions from the Department of Justice and Equality in November 2020, has clarified that: 'numbers of arrivals under the IHAP programme are recorded only when the beneficiaries themselves notify the Department of their arrival in the State. This is an ongoing process that can result in the numbers of arrivals in any given year changing retrospectively over time.' Correspondence with Department of Children, Equality, Disability, Integration and Youth, November 2020. 


\section{INSTITUTIONAL CHANGES}

Changes were made to the structure of immigration-related functions within the Department of Justice and Equality in late 2019, arising from the transformation process. The Department of Justice and Equality was divided into two pillars Criminal Justice, and Civil Justice and Equality. Functions across immigration, including those under the aegis of the Irish Naturalisation and Immigration Service (INIS), were restructured as part of this process.

The functional model under the transformation programme led to the amalgamation of immigration functions such as Policy and Legislation with similar functions under the Civil Justice and Equality Pillar. Immigration Service Delivery (ISD), covering services provided by the INIS, ${ }^{4}$ is also included under this pillar. The reception and accommodation of international protection applicants was also included under ISD. See the institutional chart provided at Figure 1.1 for further detail.

It should be noted that this describes the position up to 31 December 2019. The transfer of certain functions to different Government Departments during 2020 will be addressed in the report of this series covering 2020 developments.

\section{INTERNATIONAL DEVELOPMENTS}

In December 2019, Ireland was examined by the UN Committee on the Convention on the Elimination of all Forms of Racial Discrimination (CERD) on its joint fifth to ninth Periodic Report to the Committee, which had been submitted in October 2018. The Committee published its Concluding Observations on 12 December 2019. The Committee noted positive developments including the transposition of the EU Reception Conditions Directive 2013/33/EU into Irish law and the International Protection Act 2015. The Concluding Observations made several recommendations of relevance to migration including in relation to data collection; racial profiling; racist hate speech and hate crime; political participation; education; and refugees and stateless persons. Reform of the direct provision system and the development of an alternative reception model was one of the key recommendations made by the Committee to Ireland, in relation to which Ireland was requested to report back in the next reporting period.

Ireland participated at the United Nations High Commissioner for Refugees (UNHCR) Global Refugee Forum in December 2019, and the Irish Government made pledges in relation to resettlement for the period 2020-2023 (see also

This report refers to the Irish Naturalisation and Immigration Service (INIS) when reporting developments up to December 2019. For developments after December 2019, or comments received during 2020, the report refers to Immigration Service Delivery (ISD). 
Section 4.4.2). In addition, Ireland made a financial pledge of $€ 15.5$ million to UNHCR for 2020.

Ireland's international development strategy A Better World was published in February 2019. This new strategy has a realigned focus on gender equality, climate action, good governance and combating poverty. It provides a framework for the achievement of Ireland's commitment to reach the international target for overseas development aid of 0.7 per cent Gross National Income (GNI) by 2030 as economic circumstances permit. In doing so, Ireland's investments are in accordance with the principle of reaching the 'furthest behind first'. In the strategy, Ireland reaffirmed its commitment to follow through on the goals of the Global Compact on Refugees and the Global Compact on safe, orderly and regular migration and to continue to be active in multilateral efforts to protect refugees and people on the move. Ireland also published the Strategy for Partnership with Small Island Developing States and the new Africa Strategy Global Ireland Ireland's Strategy for Africa to 2025 during 2019.

\section{ECONOMIC MIGRATION}

The General Scheme of the Employment Permits (Consolidation and Amendment) Bill was launched in October 2019, and a public consultation phase was launched in December 2019. The General Scheme includes proposals for a seasonal employment permit and a special circumstances employment permit.

The proposal for a seasonal permit would provide for a non- European Economic Area (EEA) national to work in the Irish State temporarily while retaining a legal domicile in a third country, for the purposes of employment in a sector of seasonal activity.

The proposal for a special circumstances employment permit would cover an occasional need which may arise to grant an employment permit that does not comply with standard criteria but would nevertheless be beneficial for the social or economic development of the State.

Three sets of amended employment permits regulations were passed during 2019 to make changes to the employment permits occupations lists to adjust for skills needs and certain other amendments to the Employment Permits Regulations 2017. The Employment Permits (Amendment) (No. 2) Regulations 2019 provided for increases in remuneration thresholds for critical skills employment permits, and an extension of the duration of the labour market needs test that is required to be conducted across Ireland and the European Economic Area (EEA) from 2 weeks to 4 weeks. Both these changes were applicable from 1 January 2020. 
Changes to immigration arrangements for spouses and de facto partners of Critical Skills Employment Permit Holders and researchers with a Hosting Agreement under Directive 2005/71/EC were announced on 6 March 2019. The new arrangements provided for immediate and full access to the labour market for spouses and de facto partners of Critical Skills Employment Permit Holders. From 6 March 2019, the INIS granted eligible spouses and de facto partners immigration permission on Stamp 1G, with access to the labour market without the requirement to obtain an employment permit.

\section{RECEPTION CONDITIONS}

Pressure on accommodation supply for protection applicants continued to pose a challenge during 2019. The use of temporary emergency accommodation was a particular challenge.

As of 11 November 2019, 39 accommodation centres were operating throughout the State, with an approximate capacity of 6,140 bed spaces, accommodating 6,058 persons. In 2019, 3,847 new applicants were accommodated by the International Protection Accommodation Services (IPAS), which represented 80.7 per cent of 4,767 new protection applications to the IPO (not including applications under the IRPP).

In addition, as of 11 November 2019, due to the sharp rise in international protection applications, the Department of Justice and Equality was using 37 hotels and guesthouses to provide temporary short-term accommodation for approximately 1,500 people. The Department stressed that this was a temporary measure, to be continued only until such time as sufficient places were available within the system to accommodate all protection applicants who wish to avail of the offer of accommodation while their application is being processed.

Commentators including the Ombudsman and the Irish Refugee Council (IRC) expressed serious reservations about the use of emergency accommodation. This was a central theme in the Ombudsman's commentary on direct provision - The Ombudsman and Direct Provision: Update for 2019. Some complaints received by the Ombudsman in relation to difficulties with access to medical services and Personal Public Service Numbers (PPSNs) were linked to emergency accommodation.

At a hearing before the Joint Committee on Justice and Equality, officials of the Department of Justice and Equality indicated that they were working towards formalising the most important standards for those in emergency accommodation including child protection, educational needs and health screening. 
There were continued difficulties during 2019 with the opening of new accommodation centres, due to opposition in local communities. Due to the commercially sensitive nature of the procurement process, the Department of Justice and Equality is unable to publicly comment until contractual arrangements are finalised.

Accommodation centres were opened in 2019 at: Borrisokane with own-door accommodation for up to 16 families; Ballinamore with 25 own-door apartments for up to 25 families; and Ennis for up to 64 individuals. A public information website, https://accommodationcentres.ie, has been established, which provides general information on new accommodation centres, including capacity and impact on local services (health, education and social protection) and encourages members of the community to join local 'Friends of the Centre' groups.

In August 2019, the Department of Public Expenditure and Reform published an expenditure review on the direct provision system. The review was published as part of a series of 18 spending reviews across Government Departments. The spending review of the direct provision reception system was conducted by the Irish Government Economic and Evaluation Service (IGEES) unit of the Department of Justice and Equality with input from the Reception and Integration Agency and the INIS. The Review noted that expenditure on direct provision accommodation was likely to reach $€ 120$ million in 2019 , compared with $€ 78$ million in 2018 . This increase was impacted by the increase in the number of applicants seeking accommodation; the quality standards improvements required of accommodation providers; and pressure on costs from the need to procure temporary emergency accommodation.

National Quality Standards for Accommodation Centres were published in 2019. The draft National Standards are intended to meet the criteria set out in both European Asylum Support Office (EASO) Guidance on Operational Standards and Indicators and the Reception Conditions Directive (2013/33/EU). The Standards were agreed following an extensive consultative process with UNHCR and relevant non-governmental organisations (NGOs).

Vulnerability assessment to identify special reception needs at the beginning of the asylum procedure was also a topical issue during 2019. A group of eight NGOs called on the Government to introduce a vulnerability assessment, arguing that this is a specific legal requirement following Ireland's transposition of the Reception Conditions Directive (2013/33/EU) into Irish law in June 2018. Speaking at the Joint Committee on Justice and Equality, Department officials indicated that they were meeting the legal requirements for vulnerability assessments but were working towards improvements. UNHCR also pointed out that vulnerability 
assessment is provided for in the new National Quality Standards for Accommodation Centres.

In June 2019, the Department of Education and Skills announced the extension for the fifth year of the student support scheme for access to third level education for persons in the protection process for the academic year 2019/2020. In 2019, the eligibility criteria were reduced from five years in the Irish school system to three years, in line with the requirements for the wider Student Grant Scheme. This change was welcomed by the IRC, which had raised it as an issue in previous years.

In December 2019, the Minister and Minister of State at the Department of Justice and Equality announced the establishment of the Expert Group on the Provision of Support, including Accommodation, to Persons in the International Protection Process (Asylum Seekers), chaired by Dr Catherine Day, former Secretary General of the European Commission. The membership of the expert group included relevant NGOs (Nasc, the Irish Refugee Council and the Movement of Asylum Seekers in Ireland (MASI). The expert group was due to report by the end of 2020.

\section{IRISH REFUGEE PROTECTION PROGRAMME (IRPP)}

The Minister of State at the Department of Justice and Equality announced plans to resettle up to 2,900 refugees under a new phase of the IRPP through a combination of resettlement and community sponsorship between 2020 and 2023 at the Global Refugee Forum held by UNHCR in Geneva on 18 December 2019. This would see 650 resettlements in 2020, 700 in 2021, 750 in 2022 and 800 in 2023.

Community Sponsorship Ireland was launched as a national programme on 11 November 2019, following a pilot phase that commenced in December 2018. Five families (17 persons) were resettled by host community groups in Cork, Waterford and Meath during the pilot phase.

Community Sponsorship is an alternative resettlement stream to the traditional state-centred model. The initial pilot model sought to enable interested groups within a community to come together to support arriving refugees as a Community Sponsorship Group (CSG). The local group provides supports around access to housing and to different state services. Refugees arrive in Ireland following selection by UNHCR and a vetting process overseen by the IRPP. The Irish model was developed in co-operation with the Government of Ireland, Refugees and Citizenship Canada (RCC), and civil society organisations such as UNHCR, the Irish Red Cross, Nasc, IRC and Amnesty International Ireland. 


\section{UNACCOMPANIED MINORS AND OTHER VULNERABLE GROUPS}

In January 2019, Ireland pledged to accept five unaccompanied minors from Malta, following discussions with the European Commission and the Maltese authorities. These unaccompanied minors were part of a group of 298 migrants disembarked in Malta as a result of search and rescue missions in the Mediterranean. Some four of these minors had arrived by the end of 2019.

As reported for 2018 , Ireland committed to accepting 36 unaccompanied minors from Greece on a bilateral basis in December 2018. A Tusla-led mission to Athens took place in September 2019 and eight minors were assessed, screened and approved for relocation to Ireland.

The final Children's Rights Alliance (CRA) Report Card under the Programme for a Partnership Government (2016-2020) covering 2019 marked the developments for refugee and asylum-seeking children as a ' $C+$ ', an improvement over the ' $C$ ' grade awarded for 2018. This reflected progress in relation to resettlement with the commitments to accept further refugees made in December 2019 under a new phase of the IRPP; the increase in the weekly direct provision payment for children in March 2019; and the publication of the National Standards for Accommodation Centres. However, the report card expressed concerns about the inappropriateness of emergency accommodation for children.

The Ombudsman for Children's Office (OCO) carried out a consultation with children living in direct provision accommodation, arising from a commitment in its Strategic Plan 2019-2021. The results of this research will be published in 2020.

Legislation was passed in 2019 to give full effect to provisions of the Istanbul Convention on preventing and combating violence against women and domestic violence. ${ }^{5}$ Ireland ratified the Istanbul Convention on 8 March 2019.

IOM Ireland produced Responding to sexual and gender-based violence - Guidance for International Protection Accommodation Centre Managers and Personnel during 2019. This work was part of the EU-funded PROTECT ${ }^{6}$ project, in which IOM Ireland participates with IOM offices from 11 other EU Member States. The guidelines take account of the recommendations made in the Istanbul Convention on preventing and combating violence against women and domestic violence. They were drawn up in consultation with migrant women living in international

The Criminal Law (Extraterritorial Jurisdiction) Act 2019 (No. 6 of 2019).

PROTECT - Preventing sexual and gender-based violence against migrants and strengthening support to victims project - 2019/2020. This project is funded under the European Union's Rights, Equality and Citizenship Programme (20142020). 
protection accommodation centres as well as organisations working in the area of sexual and gender-based violence and/or migrant communities.

\section{VISA POLICY}

Ireland abolished its re-entry visa system for holders of an Irish Residence Permit (IRP) or the former Garda National Immigration Bureau (GNIB) card with effect from 13 May 2019. This system had required non-EEA nationals from visa-required countries who were legally resident in Ireland and had registered their residence with the immigration authorities to apply for a re-entry visa to travel to and from Ireland. The re-entry visa was applied for from within the State. The new system does not remove the requirement for visa-required nationals to apply for a visa in advance of travel to Ireland.

In June 2019, Ireland announced a new five-year multi-entry tourist visa option for Chinese nationals, which became available from 1 July 2019. Previously, one-year, two-year and three-year tourist visa options were available. The year-year multientry option was already available to business visitors. The announcement was made on the 40th anniversary of the establishment of diplomatic relations between Ireland and China, and in the context of Tourism Ireland's commitment to growing the Chinese travel market in future years.

\section{IMMIGRATION PRECLEARANCE}

Immigration preclearance was extended in 2019 to non-EEA national de facto partners of Irish citizens from both visa-required and non-visa-required countries. Under the new procedure, non-EEA national de facto partners of Irish citizens can apply for their permission to reside in Ireland prior to arrival in the State and can register with the immigration authorities and have access to the labour market immediately on arrival. Under previous arrangements, the application for residence permission could commence only on arrival in the State, without access to the labour market while the application was pending.

The requirement to obtain a preclearance letter to travel to Ireland for this category applied from 1 November 2019.

\section{RETURN}

In December 2019, Ireland led a Frontex Joint Return Operation (JRO) in cooperation with Belgium and Iceland. In total 23 people were deported from Ireland as part of this operation. The individuals were of Albanian and Georgian nationality. 
Section 3(1) of the Immigration Act 1999 was amended to confirm that the Minister's power to make a deportation order is subject to the prohibition of refoulement set out in section 3A of the Immigration Act 1999, which was inserted by section 95 of the Withdrawal of the United Kingdom from the European Union (Consequential Provisions) Act 2019.

The IOM, funded by the Department of Justice and Equality, offers voluntary assisted return and reintegration programmes for asylum seekers, rejected asylum seekers and other illegally present migrants in vulnerable situations. The top five countries of citizenship for IOM-assisted return in 2019 were South Africa, Georgia, Brazil, USA and Ethiopia.

\section{INTEGRATION}

The Migrant Integration Strategy 2017-2020: Progress Report to Government was published in June 2019.

The Progress Report measures the implementation of each of the commitments in the Strategy. It highlighted a number of examples of achievements at the mid-term stage, including the Education (Admission to Schools) Act 2018; ${ }^{7}$ the Second National Intercultural Health Strategy; the Communities Integration Fund; commencement of an Office for the Promotion of Migrant Integration (OPMI)/ESRI Integration Research Programme; and mapping of data needs for monitoring integration. It also noted that challenges had been experienced with monitoring progress on actions 'with a process focus and/or are crosscutting'. The importance of integration monitoring data to prioritise implementation of actions was also noted. Further action to combat racism and xenophobia and more synergies between Local Authority work and the National Strategy were identified as aims for the remainder of the Strategy.

To coincide with publication of the Progress Report, the Minister of State at the Department of Justice and Equality announced that an anti-racism committee would be established later in 2019. The Minister subsequently announced the establishment of the committee, to be chaired by Professor Caroline Fennell of University College Cork and a commissioner of the Irish Human Rights and Equality Commission (IHREC), and with a membership including both State and non-State actors, during his address at Ireland's examination by the UN Committee on the Convention on the Elimination on Racial Discrimination (CERD) in December 2019.

The Education (Admission to Schools) Act 2018 is intended to create a more parent-friendly, equitable and consistent approach to how school admissions policies operate for all primary and post-primary schools. This will help to ensure that all children, regardless of nationality or religion, are able to access education. (Migrant Integration Strategy: Progress Report to Government), p. 7. 
The Immigrant Council of Ireland (ICI) again ran the Transport Against Racism campaign in co-operation with Transport for Ireland in 2019. In addition, under the training heading of the Integration Hub project, the $\mathrm{ICI}$ ran 32 anti-racism and diversity workshops, reaching 457 people.

The Department of Justice and Equality launched a consultation on hate speech in October 2019. This was part of the review of existing law in this area, the Prohibition of Incitement to Hatred Act 1989.

An Garda Síochána published its Diversity and Integration Strategy 2019-2021 in October 2019. The Strategy is structured around five priorities - Protecting the Community; Data; Our People; Partnership; and Communication. The Strategy also included the development by An Garda Síochána of a working definition of hate crime and a non-crime hate incident.

Funding of $€ 4.5$ million was made available under the Asylum Migration and Integration Fund (AMIF) in 2019 over the period 2019-2022 for projects to promote the integration of migrants, including in relation to English language classes and workplace training.

Funding of $€ 526,000$ was announced in July 2019 for 124 community projects under the Communities Integration Fund, which was originally established in 2017. In 2019, the Office of Public Works made additional funding of $€ 26,000$ available on a once-off basis for projects focused on the arts.

Local elections were held in Ireland in June 2019. The ICI re-ran the videos from its 2018 \#GoVote! campaign to encourage migrants to vote just before the elections in 2019. A progress report on the internship scheme where five migrants interned with councillors was also published in 2019. The ICI noted in its 2019 Impact Report that just nine councillors with a migrant background were elected out of a total of 949 councillors across Ireland, and emphasised its ongoing work encouraging migrant political participation, which included 17 political participation training workshops across Ireland, reaching 242 people.

Detail on integration research published during the year by the ESRI under the OPMI/ESRI research programme and by EMN Ireland is included at Section 7.1.7.

\section{CITIZENSHIP AND NATURALISATION}

Under the Irish Nationality and Citizenship Act 1956 (as amended), in order to apply for naturalisation, an applicant must have a total 'reckonable residence' of five years during the previous nine years, including one year of continuous residence 
prior to the application. A 'six-week rule' operates on an administrative basis, in order to provide for short-term and temporary absences from the State.

In July 2019, the discretionary six-week rule was found by the High Court to be unlawful. Barrett J held in Jones $v$ Minister for Justice and Equality that 'continuous residence', as set down in the Irish Nationality and Citizenship Act 1956, as amended, means unbroken and uninterrupted residence, thus no absence is legally allowed. The judgment was subsequently appealed by the applicant and was heard at the Court of Appeal on 8 October 2019. On 14 November 2019, the Court of Appeal delivered its judgment in which it held that the High Court erred in law in stating that naturalisation applicants must have unbroken residence in the year prior to their application, which the Court of Appeal stated was 'unworkable, overly literal, unduly rigid and gives rise to an absurdity'. ${ }^{8}$ Full case summaries are available at Section 7.2.5.

\section{TRAFFICKING}

Ireland dropped to Tier 2 Watchlist status for the first time in the United States State Department's Trafficking in Persons Report 20th edition (TIP report), which covers developments for $2019 .{ }^{9}$ Ireland had maintained Tier 2 status for the two previous years and had held Tier 1 status between 2011 and 2016. The TIP report measures the efforts of states to eliminate human trafficking against the minimum standards set in the US Trafficking Victims Protection Act. According to the Tier 2 Watch List rating:

The Government of Ireland does not fully meet the minimum standards for the elimination of trafficking but is making significant efforts to do so. These efforts included increasing prosecutions and funding to NGOs for victim assistance. The government also increased the number of police and immigration officers that received anti-trafficking training and reorganized its antitrafficking coordination unit. However, the government did not demonstrate overall increasing efforts compared to the previous reporting period. ${ }^{10}$

Ireland ratified the International Labour Organisation (ILO) Forced Labour Protocol $^{11}$ in February 2019. The Protocol reinforces the international legal framework for combating all forms of forced labour, including trafficking in

Roderick Jones v Minister for Justice and Equality [2019] IECA 285.

The scope of the 20th edition is 1 April 2019 to 31 March 2020.

US State Department (2020) Trafficking in Persons Report 20th edition, p. 269. Available at: https://state.gov.

Protocol of 2014 to the Forced Labour Convention, 1930. See https://www.ilo.org/dyn/normlex/en/f?p=NORMLEXPUB:12100:0::NO::P12100_ILO_CODE:P029. 
persons. This initiative was led by the Department of Business, Enterprise and Innovation. Ireland was the 29th ILO Member State to ratify the Protocol.

The Criminal Justice (International Cooperation) Act 2019 made further provision to better facilitate the participation of members of An Garda Síochána in joint investigation teams. Section 6 of this Act amended section 51 of the Garda Síochána Act 2005 to enable the assignment of eligible members of An Garda Síochána for service outside of the State, including to act as members of a joint investigation team in accordance with the 2002 EU Council Framework Decision on joint investigation teams, which may include joint investigation teams to combat trafficking in human beings.

Ireland announced that the Irish Human Rights and Equality Commission would be designated as Ireland's national rapporteur at the meeting of the EU Network of National Rapporteurs or Equivalent Mechanisms on Trafficking in Human Beings on 4 and 5 December 2019. ${ }^{12}$

Agreement on the scope of a research project was reached with Maynooth University in January 2019 with a view to providing funding for a research project that will examine victim perspectives of trafficking for the purposes of sexual exploitation in Ireland, their view and understanding of the judicial system and the Criminal Law (Sexual Offences) Act 2017 and to map the legal, policy and theoretical context of sex trafficking in Ireland.

A mediation agreement was reached in April 2019 in relation to concerns raised in 2018 by the International Transport Workers' Federation (ITWF) about employment conditions and suspected trafficking of non-EEA fishermen in the Irish fishing fleet. The ITWF had sought a moratorium on the issue or renewal of atypical work permissions to workers in the Irish fishing fleet and threatened High Court proceedings. The main terms of the agreement between the parties included that participants in the scheme should receive their contract of employment in their native language as well as English; no employment permission is granted without a contract to a specific employer; non-EEA fishers retain the right to transfer employment within the scheme, without the existing or previous employer's consent; that Ireland should transpose EU Directive $2017 / 159^{13}$ by 15 November 2019; and that the relevant bodies would liaise on the enforcement of S.I. No. 709

The Minister for Justice signed regulations to make IHREC Ireland's national rapporteur on 22 October 2020. Council Directive (EU) 2017/159 of 19 December 2016 implementing the Agreement concerning the implementation of the Work in Fishing Convention, 2007 of the International Labour Organisation, concluded on 21 May 2012 between the General Confederation of Agricultural Cooperatives in the European Union (Cogeca), the European Transport Workers' Federation (ETF) and the Association of National Organisations of Fishing Enterprises in the European Union (Europêche). 
of 2003 relating to the hours of work and rest on board fishing vessels. For further detail, see Section 8.4.1.

The Workplace Relations Commission (WRC) also upheld several complaints made by non-EEA fishermen against their employers in relation to payment of wages and other employment rights. For example, in January 2019, an award of almost $€ 40,000$ was made in relation to underpayment of wages, excessive working hours and breaches in relation to rest breaks, leave and public holidays. ${ }^{14}$

As in previous years, the Department of Justice and Equality, An Garda Síochána and other organisations continued to engage in a wide range of training and awareness-raising activities, which are detailed in Chapter 8.

14 A crew member $v$ A fishing boat owner / operator Adjudication 00012854, 3 January 2019. Available at: https://www.workplacerelations.ie/en/search/?decisions. 


\section{CHAPTER 1}

\section{Introduction}

This report is the sixteenth in a series of Annual Reports on Migration and Asylum, a series which is intended to provide a coherent overview of migration and asylum trends and policy development during consecutive periods beginning in January 2003. Prior to 2016 these reports were called Annual Policy Reports. Previous comparable Annual Reports on Migration and Asylum are available for a number of other countries participating in the European Migration Network (EMN). The purpose of the EMN report is to provide an insight into the most significant political and legislative (including EU) developments at State level, as well as public debates, in the area of migration and asylum.

In accordance with Article 9(1) of Council Decision 2008/381/EC establishing the EMN, the EMN National Contact Points (NCPs) in each Member State and Norway are tasked with providing an annual report detailing the migration and asylum situation in the Member State, including policy developments and statistical data. The information used to produce this report is gathered according to commonly agreed EMN specifications developed to facilitate comparability across countries. Each EMN NCP produces a national report and a comparative synthesis report is then compiled, which brings together the main findings from the national reports and places them within an EU perspective.

All current and prior reports are available at www.emn.ie. ${ }^{15}$

The EMN Annual Report on Migration and Asylum 2019: Ireland covers the period 1 January 2019 to 31 December 2019.

\subsection{METHODOLOGY}

For the purposes of the 2019 report, specific criteria regarding the inclusion of significant developments and/or debates have been adopted to ensure standard reporting across all national country reports. On an EMN central level, a 'significant development/debate' within a particular year was defined as an event that had been discussed in parliament and had been widely reported in the media. The longer the time of reporting in the media, the more significant the development. Developments will also be considered significant if they subsequently led to any proposals for amended or new legislation.

15 Available National Reports from other EMN NCPs can be found at http://ec.europa.eu/dgs/home-affairs/what-wedo/networks/european_migration_network/index_en.htm. 
A significant development is defined in the Irish report as an event involving one or more of the following:

- all legislative developments;

- major institutional developments;

- major debates in parliament and between social partners;

- Government statements;

- media and civil society debates;

- the debate is engaged with in parliament;

- items of scale that are discussed outside a particular sector and as such are considered newsworthy while not being within the Dáil remit;

- academic research.

Sources and types of information used generally fall into several categories:

- published and adopted national legislation;

- Government press releases, statements and reports;

- published Government schemes;

- media reporting (both web-based and print media);

- other publications (e.g. European Commission publications; Annual Reports, publications and information leaflets from IGOs and NGOs);

- case law reporting.

Statistics, where available, were taken from published first-source material such as Government/other annual reports, and statistics from the Central Statistics Office (CSO) and Eurostat. Where noted, and where it was not possible to access original statistical sources, data may be taken from media articles based on access to unpublished documents. Where possible, verified data have been used; where provisional data have been included, this has been highlighted.

In order to provide a comprehensive and reflective overview of national legislative and other debates, a sample of core partners were contacted with regard to input on a draft report:

- Department of Business, Enterprise and Innovation (DBEI); 
- Department of Justice and Equality/Justice (DJE/DoJ); ${ }^{16}$

- Department of Children, Equality, Disability, Integration and Youth (DCEDIY);

- Child and Family Agency, Tusla;

- Immigrant Council of Ireland (ICI);

- International Organization for Migration (IOM) Ireland;

- Irish Refugee Council (IRC);

- International Protection Office (IPO);

- International Protection Appeals Tribunal (IPAT);

- Migrant Rights Centre Ireland (MRCl);

- Nasc, Refugee and Migrant Rights Centre (Nasc);

- United Nations High Commissioner for Refugees (UNHCR) Ireland.

All definitions of technical terms or concepts used in the study are as per the EMN Migration and Asylum Glossary 7.0. ${ }^{17}$

Three departments are involved in migration management in Ireland (see Figure 1.1).

In addition, the Child and Family Agency, Tusla, is responsible for administration of the care for unaccompanied third-country minors in the State and, since November 2020, sits under the Department of Children, Equality, Disability, Integration and Youth (DCEDIY). ${ }^{18}$

Figure 1.1 sets out institutional arrangements as at 31 December 2019. The chart sets out the position throughout 2019, including the changes brought about by the transformation process in the Department of Justice and Equality which took place late in 2019. These changes are described in Section 1.2.1.

16 The Department of Justice and Equality changed name to Department of Justice with effect from 1 November 2020. Where comments or contributions to this report were received from November 2020, the Department is referred to as the Department of Justice. Where comments or contributions were received prior to November 2020, the Department is referred to as the Department of Justice and Equality. In addition, certain functions of the Department of Justice and Equality, in relation to integration, reception and the Irish Refugee Protection Programme, were transferred to the Department of Children, Equality, Disability, Integration and Youth (DCEDIY) from November 2020. Available at www.emn.ie and http://ec.europa.eu/dgs/home-affairs/what-we-do/networks/european_migration_ network/glossary/index_a_en.htm.

18 The Department of Justice and Equality changed name to Department of Justice with effect from 1 November 2020. In addition, certain functions of the Department of Justice and Equality, in relation to integration, reception and the Irish Refugee Protection Programme, were transferred to the Department of Children, Equality, Disability, Integration and Youth from November 2020. 


\subsection{STRUCTURE OF MIGRATION AND ASYLUM POLICY}

FIGURE 1.1 INSTITUTIONS IN IRELAND WITH RESPONSIBILITY FOR ASYLUM AND IMMIGRATION 2019

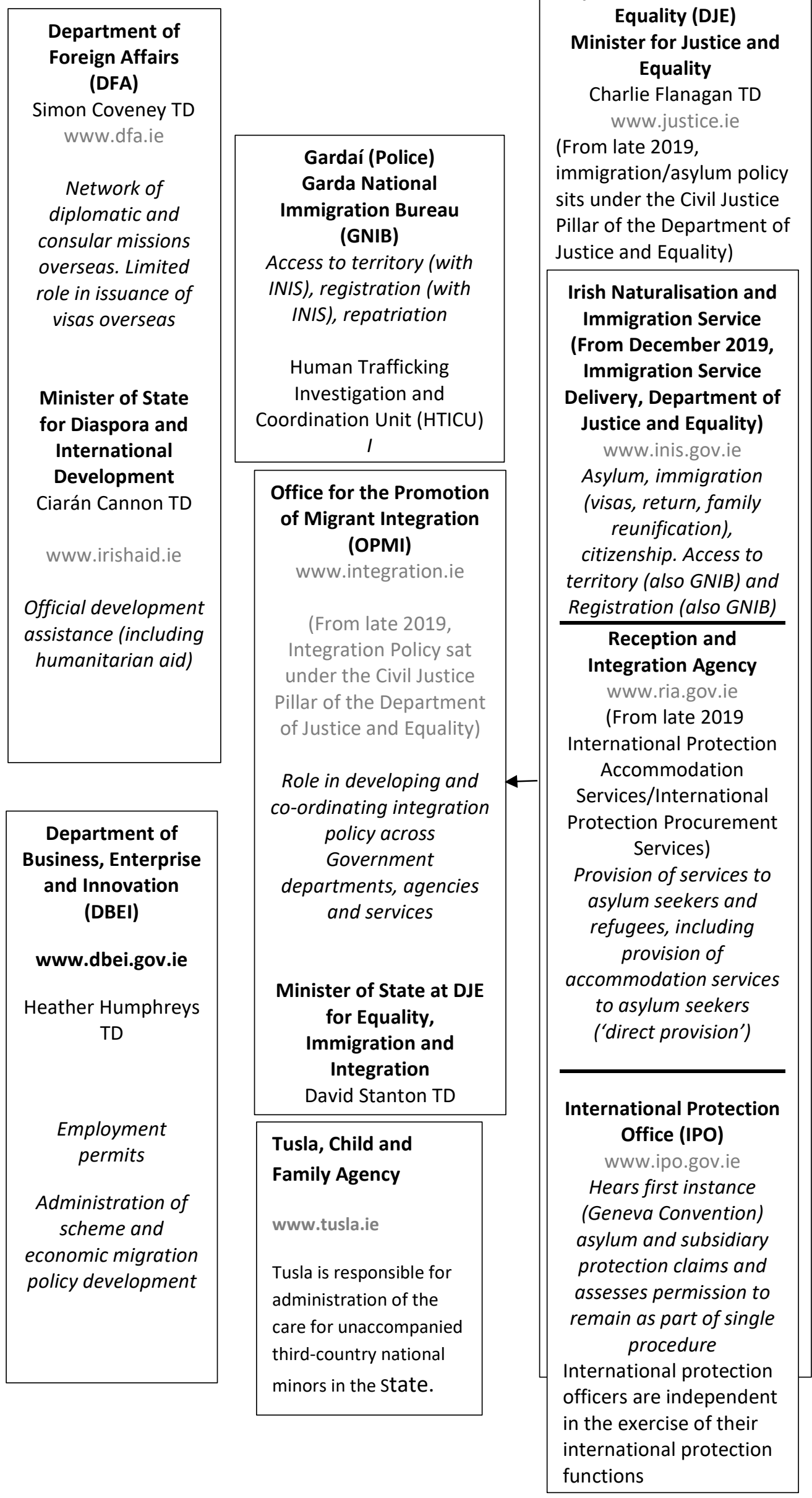

International Protection Appeals Tribunal (IPAT)) www.protectionappeals. ie

Decides (Geneva Convention) asylum and subsidiary protection appeals, Dublin system appeals and reception conditions appeals.

Statutorily independent

\section{Legal Aid Board}

www.legalaidboard.ie

Refugee Legal Service

Provides legal aid to international protection applicants and advice in other immigration cases. 


\subsubsection{Structure of the immigration system}

The account below describes the situation as at 31 December 2019. During 2019, the Department of Justice and Equality went through a restructuring process. As part of this, the Department of Justice and Equality was divided into two pillars Criminal Justice, and Civil Justice and Equality. Immigration policy and legislation were positioned under the Civil Justice pillar. The Irish Naturalisation and Immigration Service (INIS) was restructured as the Immigration Service Delivery (ISD) function of the Department of Justice and Equality. The Reception and Integration Agency (RIA) was restructured into two units - International Protection Accommodation Services (IPAS) and International Protection Procurement Services (IPPS) under the ISD function. The Office for the Promotion of Migrant Integration (OPMI) was also positioned under the civil justice pillar. Updated institutional structures since the formation of the new Government in 2020 will be described in the next report of this series.

\section{Department of Justice and Equality}

The Department of Justice and Equality ${ }^{19}$ is responsible for immigration management. The Minister for Justice and Equality has ultimate decision-making powers in relation to immigration and asylum. The Garda National Immigration Bureau (GNIB) is responsible for all immigration-related Garda operations in the State and is under the auspices of An Garda Síochána (national police force) and, in turn, the Department of Justice and Equality. The GNIB enforces deportations and border control and carries out investigations related to illegal immigration and trafficking in human beings. Since 2015, the INIS ${ }^{20}$ of the Department of Justice and Equality has implemented a civilianisation project to take over frontline border control functions at Dublin Airport. GNIB also carries out the registration of nonEEA nationals, who are required to register for residence purposes, at locations outside Dublin. Since 2016, the registration function is carried out by the INIS/ISD in Dublin. An Garda Síochána has personnel specifically dealing with immigration in every Garda district, at all approved ports and airports, and at a border control unit attached to Dundalk Garda Station.

In addition, trafficking policy is the responsibility of the Criminal Justice pillar of the Department of Justice and Equality. There are three other dedicated units dealing with this issue: the Human Trafficking Investigation and Co-ordination Unit in the Garda National Protective Services Bureau (GNPSB), the Anti-Human Trafficking Team in the Health Service Executive (HSE) and a specialised human trafficking legal team in the Legal Aid Board (LAB). Dedicated personnel are assigned to deal with prosecution of cases in the Office of the Director of Public Prosecutions (DPP),

19 From 1 November 2020, Department of Justice, www.justice.ie.

20 From December 2019, INIS is the Immigration Service Delivery function of the Department of Justice and Equality www.inis.gov.ie. 
as well as in the New Communities and Asylum Seekers Unit within the Department of Social Protection, which is tasked with providing assistance to suspected victims not in the asylum system with their transition from direct provision accommodation to mainstream services for the duration of their temporary residency.

From December 2019, the ISD function of the Department of Justice and Equality (formerly the INIS) is responsible for administering the statutory and administrative functions of the Minister for Justice and Equality in relation to asylum, visa, immigration and citizenship processing, and return decisions. The RIA was a separate office within the Department of Justice and Equality, responsible for arranging accommodation and working with statutory and non-statutory agencies to co-ordinate the delivery of other services (including health, social services, welfare and education) for applicants for international protection. ${ }^{21}$ From December 2019, RIA was divided into International Protection Accommodation Services (IPAS) and International Protection Procurement Services (IPPS). Since 30 June 2018, the statutory basis for this work is the European Communities (Reception Conditions) Regulations 2018, ${ }^{22}$ which transpose the EU Reception Conditions Directive 2013/33/EU into Irish law. Since 2004, it has also been responsible for supporting the voluntary return, on an ongoing basis and for the Department of Employment Affairs and Social Protection, ${ }^{23}$ of destitute nationals of the 13 Member that which have joined the EU since 2004. It also provides accommodation to suspected victims of trafficking pending a determination of their case and during the 60-day recovery and reflection period. ${ }^{24}$

With regard to applications for asylum and decision-making on the granting of refugee status under the 1951 Geneva Convention relating to the status of refugees, a two-tier structure exists for asylum application processing. Up to 31 December 2016, this consisted of the Office of the Refugee Applications Commissioner (ORAC) and the Refugee Appeals Tribunal (RAT). Since 31 December 2016, with the commencement of the International Protection Act 2015, these bodies have been replaced by the International Protection Office (IPO) and the International Protection Appeals Tribunal (IPAT). These bodies have responsibility for processing first-instance applications for international protection and for hearing appeals, respectively. Since 30 June 2018, the IPAT also hears appeals in relation to the European Communities (Reception Conditions) Regulations 2018. The IPO is an office within the INIS/ISD responsible for processing applications for international protection under the International Protection Act 2015. It also

See www.ria.gov.ie, 'Functions and Responsibilities'.

S.I. No. 62 of 2018.

www.welfare.ie.

From November 2020, these functions moved to the Department of Children, Equality, Disability, Integration and Youth. 
considers, as part of a single procedure, whether applicants should be given permission to remain. International protection officers are independent in the performance of their international protection functions. The IPAT is independent in the performance of its functions under the International Protection Act 2015. ${ }^{25}$ The Department of Justice and Equality ensures that both bodies have input into the co-ordination of asylum policy.

Since 31 December 2016, the single application procedure for international protection claims under the International Protection Act 2015 has entered into operation. Under the single application procedure, applications for refugee status, subsidiary protection and permission to remain are assessed as part of a single procedure. This replaced the former sequential process, whereby applications for refugee status were assessed under the Refugee Act 1996 and applications for subsidiary protection under the European Union (Subsidiary Protection) Regulations 2013.

Under section 47(1) of the International Protection Act 2015, the Minister is bound to accept a positive recommendation of refugee status of the international protection officer or a decision to grant refugee status in relation to an appeal heard by the IPAT, but retains a discretion not to grant refugee status to a refugee on grounds of danger to the security of the State or to the community of the State where the refugee has been convicted of a particularly serious crime. ${ }^{26}$ The Minister shall refuse a refugee declaration where an international protection officer has recommended that the applicant be refused refugee status but be granted subsidiary protection status, and has not appealed the decision not to grant refugee status. The Minister is also bound by a recommendation or decision on appeal in relation to subsidiary protection status, under section 47(4) of the Act. The Minister shall refuse both refugee status and subsidiary protection status where the recommendation is that the applicant be refused both statuses and the applicant has not appealed the recommendation or when the IPAT upholds the recommendation not to grant either status. The Minister also refuses both refugee and subsidiary protection status in circumstances where appeals are withdrawn or deemed to be withdrawn.

Under section 49 of the International Protection Act 2015, the Minister is bound to consider whether or not to grant permission to remain to an unsuccessful applicant for international protection. Information given by the applicant in the original application for international protection, including at interview, and any additional information that the applicant is invited to provide is taken into account. 
From 31 December 2016, the INIS (now ISD) has been responsible for investigating applications by beneficiaries of international protection to allow family members to enter and reside in the State and for providing a report to the Minister on such applications, under sections 56 and 57 of the International Protection Act 2015.

The Refugee Documentation Centre $(R D C)^{27}$ is an independent library and research service within the LAB. ${ }^{28}$ The specialised Services for Asylum Seekers office within the LAB provides 'confidential and independent legal services' to persons applying for asylum in Ireland. Legal aid and advice is also provided in 'appropriate cases' on immigration and deportation matters. ${ }^{29}$ Additionally, the LAB provides legal services on certain matters to persons identified by the Human Trafficking Investigation and Co-ordination Unit of An Garda Síochána as 'potential victims' of human trafficking under the Criminal Law (Human Trafficking) Act 2008.

The OPMI also came under the auspices of the Department of Justice and Equality. ${ }^{30}$ Since December 2019, the functions of the OPMI became part of the civil justice pillar of the Department of Justice and Equality. ${ }^{31}$ With a focus on the promotion of the integration of legal immigrants into Irish society, the OPMI has a mandate to develop, lead and co-ordinate integration policy across Government Departments, agencies and services. Ireland joined the UNHCR-led resettlement scheme in 1998. The OPMI co-ordinates the resettlement of refugees admitted by Ireland under the programme, as well as the administration of EU and national funding for the promotion of migrant integration.

The Irish Refugee Protection Programme (IRPP) was approved by Government on 10 September 2015 in response to the migration crisis. Under this programme, the Government confirmed that Ireland will take in a total of 4,000 persons, primarily through a combination of relocation under the EU relocation mechanism and the UNHCR-led programme currently focused on resettling refugees from Lebanon.

\section{Department of Business, Enterprise and Innovation}

The Department of Business, Enterprise and Innovation ${ }^{32}$ administers the employment permit schemes.

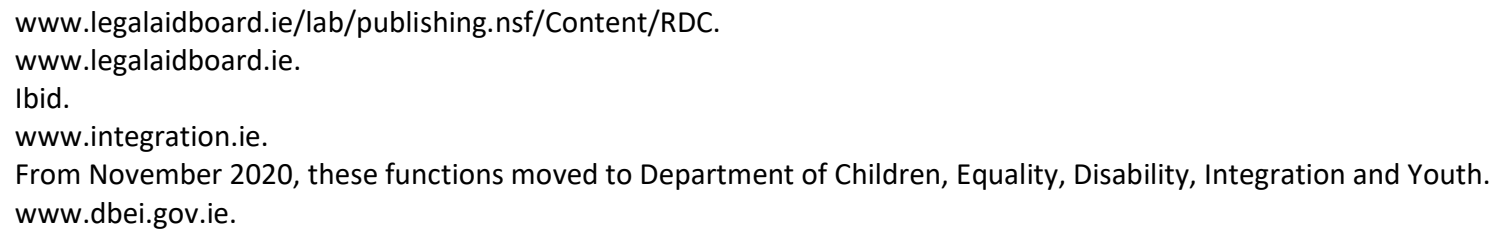


The Economic Migration Policy Unit contributes to the Department's work in formulating and implementing labour market policies by leading the development and review of policy on economic migration and access to employment in Ireland.

The Employment Permits Section ${ }^{33}$ implements a skills-oriented employment permits system in order to fill labour and skills gaps that cannot be filled through EEA supply. The Employment Permits Section processes applications for employment permits; issues guidelines, information and procedures; and produces online statistics on applications and permits issued. ${ }^{34}$

The Office of Science, Technology and Innovation deals with the administration of applications from research organisations seeking to employ third-country national researchers pursuant to Council Directive 2005/71/EC on a specific procedure for admitting third-country nationals for the purposes of scientific research.

\section{Department of Foreign Affairs and Trade}

The Department of Foreign Affairs and Trade ${ }^{35}$ has responsibility for the issuance of visas via Irish Embassy consular services in cases where the Department of Justice and Equality does not have a dedicated Visa Office within the country. ${ }^{36}$ The Department of Foreign Affairs and Trade has operative function only and is not responsible for visa policy or decisions, which are the remit of the Department of Justice and Equality.

Irish Aid, under the auspices of the Department of Foreign Affairs and Trade, administers Ireland's overseas development and humanitarian aid programme, with a particular focus on reducing poverty and hunger in countries in sub-Saharan Africa. ${ }^{37}$

\subsubsection{General structure of the legal system}

The Irish asylum process sits outside the Court system. Immigration matters are dealt with on an administrative basis by the Minister for Justice and Equality. In accordance with the Constitution, justice is administered in public, in courts established by law, with judges appointed by the President on the advice of the Government. Independence is guaranteed in the exercise of their functions. The Irish court system is hierarchical in nature and there are five types of courts in

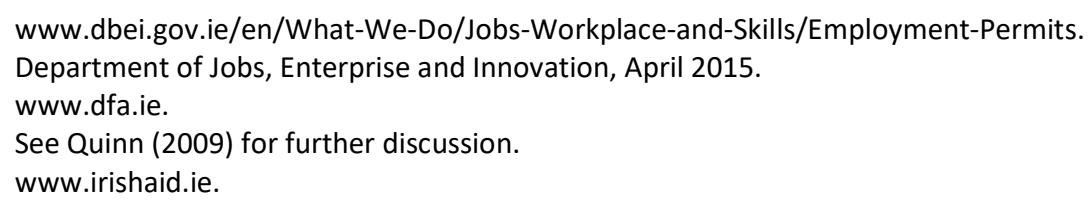


Ireland, which hear different types and levels of cases. In ascending hierarchical order, these are:

- $\quad$ the District Court;

- the Circuit Court;

- the High Court;

- the Court of Appeal;

- the Supreme Court.

The relevance of the Courts in relation to asylum and immigration cases is generally limited to judicial review. ${ }^{38}$ Judicial review focuses on assessing the determination process through which a decision is reached to ensure that the decision-maker makes their decision properly and in accordance with the law. It does not look to the merits or the substance of the underlying case. ${ }^{39}$

As discussed in previous reports in this series, prior to the mid-1990s Irish asylum and immigration legislation was covered under such instruments as the Hope Hanlon procedure and the Aliens Act 1935 (and Orders made under that Act), ${ }^{40}$ together with the relevant EU free movement Regulations and Directives ${ }^{41}$ which came into effect in Ireland after it joined the European Union in 1973. Following a sharp rise in immigration flows from the mid-1990s, several pieces of legislation were introduced to deal with immigration and asylum issues in Ireland.

The International Protection Act 2015 sets out the domestic legal framework regarding applications for international protection and replaces the Refugee Act 1996 (as amended) and the European Communities (Subsidiary Protection) Regulations 2013 (as amended). The Refugee Act 1996 has now been repealed. While Ireland participated in some of the first generation of instruments under the Common European Asylum System (the Qualification Directive 2004/83/EC and Procedures Directive 2005/85/EC), Ireland does not participate in the 'recast' Qualification Directive (2011/95/EU) and Procedures Directive (2013/32/EU).

38 There is a statutory appeal to the courts against decisions to revoke refugee status under section 52 of the International Protection Act 2015.

Available at www.citizensinformation.ie.

Aliens Order 1946 (S.I. No. 395 of 1946); Aliens (Amendment) Order 1975 (S.I. No. 128 of 1975).

Relevant EU legislation included Regulation (EEC) No. 1612/68 and repealing Directives 64/221/EEC on freedom of movement for workers within the Community, 68/360/EEC on the abolition of restrictions on movement and residence within the Community for workers of Member States and their families, 72/194/EEC on the right of citizens of the Union and their family members to move and reside freely within the territory of the Member States, 73/148/EEC on the abolition of restrictions on movement and residence within the Community for nationals of Member States with regard to establishment and the provision of services, 75/34/EEC concerning the right of nationals of a Member State to remain in the territory of another Member State after having pursued therein an activity in a self-employed capacity, 90/364/EEC on the right of residence, 90/365/EEC on the right of residence for employees and self-employed persons who have ceased their occupational activity, and 93/96/EEC on the right of residence for students. 
Ireland does not participate in the original Reception Conditions Directive (2003/9/EC). Ireland has opted into the revised Reception Conditions Directive (2013/33/EU) and the European Communities (Reception Conditions) Regulations 2018 came into operation on 30 June $2018 .^{42,43}$

Ireland is also a signatory to the 'Dublin Convention' and is subject to the 'Dublin Regulation', which determines the EU Member State responsible for processing asylum applications made in the EU. Regulation 604/2013 ${ }^{44}$ ('the Dublin III Regulation') came into force on 29 June 2013. The European Union (Dublin System) Regulations $2014^{45}$ were adopted for the purpose of giving further effect to Regulation EU 604/2013 - the Dublin III Regulation. These regulations were amended by the European Union (Dublin System) (Amendment) Regulations 2016 in 2016. ${ }^{46}$ The European Union (Dublin System) Regulations $2018^{47}$ came into effect on 6 March 2018. The Regulations give further effect to the Dublin III Regulation in Ireland and revoke the 2014 and 2016 Regulations.

S.I. No. 310 of 2008 amended the European Communities (Free Movement of Persons) (No. 2) Regulations 2006 (S.I. No. 656 of 2006) following the Metock judgment of the European Court of Justice (ECJ). The European Community (Free Movement of Persons) Regulations 2015 (S.I. No. 548 of 2015), which came into operation on 1 February 2016, give further effect to EU Directive 2004/38/EC and revoke the 2006 Regulations, subject to transitional provisions.

Domestic immigration law in Ireland is based on various pieces of legislation including the Aliens Act 1935 and Orders made under it; the Illegal Immigrants (Trafficking) Act 2000; and the Immigration Acts 1999, 2003 and 2004, as amended. The Employment Permits Act 2006 (as amended) and secondary legislation made under it set out the legal framework for the employment permits schemes in Ireland.

Regarding the situation of Ireland concerning an 'opt-in' provision on EU measures in asylum and migration, under the terms of the Protocol on the position of the United Kingdom and Ireland annexed to the Treaty on European Union (TEU) and to the Treaty on the Functioning of the European Union (TFEU), Ireland does not

\section{S.I. No. 230 of 2018.}

Note that the European Commission in July 2016 launched proposals to replace the Asylum Qualifications and Procedures Directives with Regulations and to further recast the Reception Conditions Directive.

44 Regulation (EU) No. 604/2013 (Dublin III Regulation) lays down the criteria and mechanisms for determining the Member State responsible for examining an application for international protection lodged in one of the Member States by a third-country national or a stateless person. See EMN Asylum and Migration Glossary 7.0. Available at www.emn.ie and http://ec.europa.eu/dgs/home-affairs/what-we-do/networks/european_migration_ network/glossary/index_a_en.htm.

45 S.I. No. 525 of 2014.

46 S.I. 140 of 2016. Available at www.irishstatutebook.ie.

47 S.I. No. 62 of 2018. 
take part in the adoption by the Council of proposed measures pursuant to Title $\mathrm{V}$ of the TFEU unless it decides to participate in the measure pursuant to a motion of the Houses of the Oireachtas. Under Declaration number 56 to the TFEU, Ireland has declared its

firm intention to exercise its right under Article 3 of the Protocol on the position of the United Kingdom and Ireland in respect of the area of freedom, security and justice to take part in the adoption of measures pursuant to Title $V$ of Part Three of the Treaty on the Functioning of the European Union to the maximum extent it deems possible. ${ }^{48}$

48 Declaration by Ireland on Article 3 of the Protocol on the position of the United Kingdom and Ireland in respect of the area of freedom, security and justice (TFEU). Ireland also 'affirms its commitment to the Union as an area of freedom, security and justice respecting fundamental rights and the different legal systems and traditions of the Member States within which citizens are provided with a high level of safety'. 


\section{Political and international developments and statistical context}

\subsection{POLITICAL DEVELOPMENTS}

Charlie Flanagan TD remained as Minister for Justice and Equality during 2019. David Stanton remained as Minister of State at the Department of Justice and Equality with responsibility for Equality, Integration and Inclusion.

\subsubsection{BREXIT}

As reported in 2018, the EU-UK Joint Progress Report on progress during the first phase of the negotiations under Article 50 of the Treaty on European Union recognised the impact of Brexit on the Common Travel Area between Ireland and the United Kingdom. It stated:

the United Kingdom and Ireland may continue to make arrangements between themselves relating to the movement of persons between their territories (Common Travel Area), while fully respecting the rights of natural persons conferred by Union law. The United Kingdom confirms and accepts that the Common Travel Area and associated rights and privileges can continue to operate without affecting Ireland's obligations under Union law, in particular with respect to free movement for EU citizens. ${ }^{49}$

The Withdrawal of the United Kingdom from the European Union (Consequential Provisions) Act 2019 was signed into law by the President on 17 March 2019. Part 14 of this Act deals with certain immigration-related matters. ${ }^{50}$ Section 90 provides a legal basis for taking fingerprints of Irish visa and Irish transit visa applicants, to enable the continuance of the British-Irish Visa Scheme, pursuant to Common Travel Area arrangements. Part 14 was commenced via the Withdrawal of the United Kingdom (Consequential Provisions) Act 2019 (Part 14) (Commencement) Order $2019^{51}$ in July 2019.

Throughout 2019, the Irish Naturalisation and Immigration Service (INIS) (now ISD) posted information notices relating to non- European Economic Area (EEA) national family members of British citizens residing in Ireland in light of the evolving situation regarding Brexit throughout the year. It was the intention of the Department of Justice and Equality to identify the most beneficial immigration

49 Joint report from the negotiators of the European Union and the United Kingdom Government on progress during phase 1 of negotiations under Article 50 TEU on the United Kingdom's orderly withdrawal from the European Union, 8 December 2017, paragraph 54. Available at: https://ec.europa.eu.

50 Provisions in this Act relevant to return are discussed in Chapter 7.

51 S.I. No. 346 of 2019. 
arrangement possible for this group of people in the event of a no-deal Brexit. Following the departure of the UK from the EU on 31 January 2020, the Department of Justice and Equality notified non-EEA citizen family members of British citizens that the provisions of the Free Movement Directive (2004/38/EC) would continue to apply for the duration of the transition period. ${ }^{52}$

\subsection{INSTITUTIONAL DEVELOPMENTS}

During 2019, the Department of Justice and Equality underwent a restructuring process. As part of this, the Department was divided into pillars - Criminal Justice, and Civil Justice and Equality. Functions across immigration, including those under the aegis of the INIS, were restructured as part of this process.

The functional model under the transformation programme led to the amalgamation of immigration functions such as Policy and Legislation with similar functions under the Civil Justice and Equality Pillar. Immigration Service Delivery (ISD) is also included under this pillar..$^{53}$ Services under the ISD function of the Department of Justice and Equality include: visas; border management; determination of immigration permissions for non-EEA nationals in the State; registration of residence permissions; EU Treaty Rights; citizenship applications; and repatriation.

The reception and accommodation of protection applicants in the State (formerly under the umbrella of the Reception and Integration Agency (RIA)) was divided into two new sections within the Immigration Service Delivery Function: International Protection Accommodation Services (IPAS) and International Protection Procurement Services (IPPS). IPPS takes responsibility for the procurement, contract management, inspection and payments functions associated with the accommodation provided to persons seeking international protection. Previously, this was a dedicated unit within RIA. The other functions of RIA (operations, education, and child and family services) are now the responsibility of IPAS. ${ }^{54}$

It should be noted that the foregoing describes developments up to 31 December 2019. Further institutional changes brought about by the new Government in 2020 and consequent transfer of functions to different Government departments will be addressed in the 2020 report of this series.

52 Department of Justice and Equality (31 January 2020) 'Information Notice for non-EEA family members of British citizens who are residing in Ireland'. Available at: www.inis.gov.ie.

53 See organisation charts at www.justice.ie.

54 Department of Justice and Equality (15 October 2019) Response to parliamentary question 41708/19. Available at: www.justice.ie. 


\subsection{LEGAL DEVELOPMENTS}

\subsubsection{Legislation}

The following pieces of legislation relevant to migration, international protection and trafficking in human beings were enacted during 2019. Further detail on the various thematic instruments is provided under the relevant thematic headings throughout the report.

- Criminal Justice (International Cooperation) Act 2019 (No. 27 of 2019)

- Criminal Law (Sexual Offences) (Amendment) Act 2019 (No. 4 of 2019)

- Criminal Law (Sexual Offences) (Amendment) Act 2019 (Commencement) Order 2019 (S.I. No. 436 of 2019)

- Criminal Law (Extraterritorial Jurisdiction) Act 2019 (No. 6 of 2019)

- Council of Europe Convention on Preventing and Combating Violence Against Women and Domestic Violence (Privileges and Immunities) Order 2019 (S.I. No. 78 of 2019)

- Withdrawal of the United Kingdom from the European Union (Consequential Provisions) Act 2019 (No. 8 of 2019)

- Withdrawal of the United Kingdom from the European Union (Consequential Provisions) Act 2019 (Part 14) (Commencement) Order 2019 (S.I. No. 346 of 2019)

- Employment Permits (Amendment) Regulations 2019 (S.I. No. 138 of 2019)

- Employment Permits (Amendment) (No. 2) Regulations 2019 (S.I. No. 333 of 2019)

- Employment Permits (Amendment) (No. 3) Regulations 2019 (S.I. No. 633 of 2019)

\subsubsection{Courts - judicial review}

During 2019, 368 judicial review applications were submitted to the High Court on the immigration, asylum and citizenship list, a 30 per cent decrease from the 530 appeals received in 2018. This list covers asylum-related cases and also judicial reviews against Ministerial decisions in other immigration-related matters; for example, naturalisation, EU treaty rights and family reunification. Some 262 
judicial reviews on this list were resolved by the High Court in 2019, with 135 cases settled out of Court. ${ }^{55}$

The Court of Appeal received 42 asylum list appeals in during the year, with 35 cases pending from the beginning of 2019. Some 14 cases were determined and two withdrawn in Court during the year and two were withdrawn out of Court. The Court of Appeal also had 8 'Article $64^{\prime 56}$ appeals pending before it at the beginning of the year.

As reported in previous years, initiatives had been made by the Courts Service to improve waiting times in the High Court asylum list. ${ }^{57}$ Waiting times remained stable in 2019. Waiting times had been eliminated at the pre-leave application stage in 2018, and they remained stable at post-leave application stage at two months. ${ }^{58}$

\section{High Court Practice Direction 81}

High Court Practice Direction $81^{59}$ was published by the President of the High Court on 17 December 2018 and entered into force on 1 January 2019. This practice direction applied only to cases on the immigration, asylum and citizenship list. The practice direction provided for new requirements in relation to disclosure of a wide range of information and documentation supporting a case. This included a requirement for an affidavit from adult applicants proving the information in the application and an additional affidavit from the applicant's solicitor. The practice direction required full disclosure of immigration history relevant to the application. ${ }^{60}$ It required that the applicant swear that full disclosure was made of immigration applications/representations made by the applicant and their family members inside or outside the State, and, if this was not disclosed, that they detail what was not disclosed and the extent to which efforts had been made to disclose this information to the Court. ${ }^{61}$ The Practice Direction also required that the Court's attention be drawn specifically to any 'significant matter of fact adverse to the applicant's case for relief'. It was not sufficient to provide this information by affidavit or exhibit only.

\footnotetext{
Courts Service of Ireland (July 2020) Courts Service Annual Report 2019, p.56. Available at: www.courts.ie These cases had been initiated before the Supreme Court prior to the establishment of the Court of Appeal on 28 October 2014 but had not yet been fully or partly heard prior to the Court of Appeal establishment date and were transferred to the Court of Appeal for determination. These cases are known as Article 64 cases. Sheridan, A. (November 2019) Annual Report on Migration and Asylum 2018: Ireland, pp. 66-67. Available at: www.emn.ie and www.esri.ie.

58 Courts Service of Ireland (July 2020) Courts Service Annual Report 2019, p. 108. Available at: www.courts.ie.

59 https://www.courts.ie/acc/alfresco/e5e5270d-3f71-452d-9932-5b00b12514dd/HC81\%20\%20Asylum\%2C\%20immigration\%20and\%20citizenship\%20list.docx/file\#view=fitH.

60 Ibid., section B - Statement of relevant facts.

61 Ibid., paragraph 8(a)(1).
} 
Solicitors and barristers raised concerns about the extent of these requirements of disclosure, which were particular to the asylum list. ${ }^{62}$ According to clarifications, subsequently appended to the Practice Direction, the primary purpose of the Practice Direction was to give practical effect to the requirement on all applicants to put all relevant material before the Court when making any form of ex parte application, and that primary responsibility for adherence with this principle of 'utmost good faith' rested with the applicant.

A review of the Practice Direction was ordered on 28 June 2019, six months after its entry into operation. ${ }^{63}$

\subsection{UNITED NATIONS AND OTHER INTERNATIONAL DEVELOPMENTS}

\subsubsection{Convention on the Elimination of all Forms of Racial Discrimination}

Ireland ratified the UN Convention on all Forms of Racial Discrimination (CERD) in 2000. As reported for 2018, Ireland submitted its joint fifth to ninth periodic reports to the CERD Committee in October $2018 .{ }^{64}$ The report covered the period from 2010 to 2017 and responded to the Concluding Observations of the UN CERD Committee on Ireland's third and fourth periodic reports. ${ }^{65}$

A review of the periodic report's responses to the Concluding Observations to the third and fourth periodic reports is reported in the 2018 report of this series. ${ }^{66}$

The Irish Human Rights and Equality Commission (IHREC) produced an independent shadow report for the Committee and other civil society organisations made submissions. In its shadow report, IHREC raised concerns of relevance to migrants and asylum seekers, including in relation to direct provision accommodation, the statutory limits on the right to family reunification in the International Protection Act 2015, and in relation to combating human trafficking. ${ }^{67}$

The United Nations High Commissioner for Refugees (UNHCR) submitted recommendations highlighting positive developments and ongoing areas for improvement for consideration by the Committee. The UNHCR submission

E. Edwards, 'High Court clarifies practice direction for immigration and asylum cases', Irish Times, 21 January 2019.

M. Carolan, 'Controversial direction on High Court asylum cases to be reviewed', Irish Times, 25 July 2019.

Committee on the Elimination of Racial Discrimination (3 October 2018) Combined fifth to ninth periodic reports submitted by Ireland under article 9 of the Convention, due in 2014 CERD/C/IRL/5-9, advance unedited version. Available at: www.justice.ie.

65 Committee on the Elimination of Racial Discrimination (4 April 2011) Concluding observations of the Committee on the Elimination of Racial Discrimination Ireland, CERD/C/IRL/CO/3-4.

66 A. Sheridan (November 2019) Annual Report on Asylum and Migration 2018: Ireland, pp. 18-23. Available at: www.emn.ie and www.esri.ie.

67 Irish Human Rights and Equality Commission (October 2019) Ireland and the Convention on the Elimination of Racial Discrimination: Submission to the United Nations Committee on the Elimination of Racial Discrimination on Ireland's Combined 5th to 9th Report, pp. 10-11. Available at: www.ihrec.ie. 
highlighted the single application procedure under the International Protection Act 2015 and the transposition of the Reception Conditions Directive into Irish law as positive developments. It also raised several areas of concern, with recommendations:

- the need for concrete steps to improve reception conditions for asylum seekers, including by implementing the Quality Standards for accommodation centres, ensuring early identification of vulnerabilities and working towards eliminating the use of emergency accommodation.

- to enhance integration prospects of beneficiaries of international protection (BIPs) by developing integration policy to specifically address the needs of refugees and asylum seekers

- to establish a statelessness determination procedure (SDP)

- to continue the IRPP Humanitarian Admission Programme (IHAP) and extend it to all nationalities

- to combat racism, discrimination and xenophobia towards BIPs, programme refugees and asylum seekers by creating a new National Action Plan against Racism and by developing an infrastructure to monitor and collect relevant data on discrimination and racism experienced by this group. ${ }^{68}$

Ireland was examined by the CERD Committee on the fifth to ninth periodic reports on 2 and 3 December 2019 and the Committee published its Concluding Observations on 12 December 2019. ${ }^{69}$

In his opening address to the Committee, the Minister of State at the Department of Justice and Equality announced the establishment of an anti-racism committee, including both State and non-State actors, to be chaired by Professor Caroline Fennell of University College Cork. ${ }^{70} \mathrm{He}$ also highlighted other developments including the publication of the Migrant Integration Strategy and Garda Diversity and Integration Strategy; improvements to the direct provision system; hate crime legislation; and consultation on hate speech (see Chapter 7 for further detail). ${ }^{71}$

The Committee noted positive developments in the reporting period - in particular, the transposition of the Reception Conditions Directive 2013/33/EU into

68 United Nations High Commissioner for Refugees, Ireland (25 November 2019) 'Comments. Committee on the Elimination of Racial Discrimination 100th Session 25 November - 13 December 2019 IRELAND'. Available at: www.unhcr.org.

69 Committee on the Elimination of Racial Discrimination (12 December 2019) Concluding Observations on the combined fifth to ninth reports of Ireland, CERD C/IRL/Co/5-9, advance unedited version. Available at: https://tbinternet.ohchr.org.

70 Department of Justice and Equality (2 December 2019) 'Minister Stanton delivers Ireland's National Statement to CERD in Geneva', Press Release. Available at: www.justice.ie.

71 Ibid. 
Irish law; the passage into law of the International Protection Act 2015; the publication of the Migrant Integration Strategy and the extension of the remit of the Ombudsman and the Ombudsman for Children to accept complaints from residents in direct provision accommodation centres. ${ }^{72}$

The Concluding Observations expressed many concerns and recommendations related to migration and asylum, including in relation to:

- Data collection: The Committee expressed concerns about the availability of data on the ethnic composition of the population. ${ }^{73}$

- Racial profiling: The Committee recommendations included the introduction of an independent complaints mechanism; racial profiling training for police; and the full implementation of the Garda Siochána Diversity and Integration Strategy. ${ }^{74}$

- Racist hate speech and racist hate crime: The Committee recommended strengthening of legislation in relation to hate speech and, while noting the State's efforts in relation to hate crime, it recommended the strengthening of legislation to include racist motivation as an aggravating factor. It also recommended measures to encourage better reporting of racist hate crime incidents. ${ }^{75}$

- People of African descent: The Committee expressed concern that this group experienced particular discrimination and disadvantage. While noting the consultation that had taken place, it also recommended that the State move further in developing a programme to mark the International Decade of African Descent. $^{76}$

- Participation in political and public life: The Committee recommended that the objective in the Migrant Integration Strategy of reaching 1 per cent ethnic minority representation in the civil service workforce be implemented. ${ }^{77}$

- Education: The Committee welcomed the passage of the Education (Admissions to Schools) Act 2018 into law but requested more information in the next periodic report on its impact in preventing discrimination. ${ }^{78}$

- Refugees, asylum seekers and stateless persons: The Committee expressed concerns in relation to processing backlogs and timeframes; lack of data; having an adequate mechanism for identifying asylum seekers with special reception

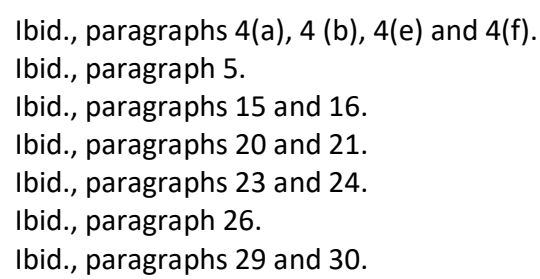


needs; the absence of a statelessness determination procedure; the ninemonth waiting period for a labour market access permission for protection applicants; and practical barriers to accessing work, including transport issues and training. It recommended a six-month processing time for protection applications; the implementation of the Department of Justice and Equality Research and Data Strategy 2018-2020; a comprehensive vulnerability assessment for reception needs; the establishment of a statelessness determination procedure; the reduction of the waiting period for labour market access permissions; and to remove barriers for protection applicants in accessing employment including providing transport and training. ${ }^{79}$

- Direct provision system: The Committee highlighted its recommendations in relation to direct provision as one of four key recommendations that the State should report back on in its next periodic report. ${ }^{80}$ Its primary recommendation was that the State implement an alternative reception model. In the interim, it recommended:

... the State party to develop an alternative reception model and take concrete steps to phase out the Direct Provision system. The Committee recommends, as interim measures, that the State party:

(a) Improve living conditions in direct provision centres and reduce the length of stay in the centres;

(b) Set up clear standards of reception conditions for direct provision centres; regulate and inspect the operation of direct provision centres; and hold those responsible accountable in case of breach of standards;

(c) Halt the emergency accommodation as soon as possible and develop a contingency planning framework with a view to effectively responding to capacity pressures;

(d) Ensure transparency regarding the deaths in direct provision centres and collect and publish data on the deaths in the centres. ${ }^{81}$

- Domestic violence: Among the Committee's recommendations was to - Ensure that migrant women, who are victims of domestic violence, sexual and genderbased violence and female genital mutilation, are guaranteed a legal stay regardless their residence status until they recover and have the option to remain in the country if they so wish ${ }^{82}$ and for full implementation of the Criminal Justice (Female Genital Mutilation) Act 2012. ${ }^{83}$

- Trafficking in human beings: The Committee recommended that the State intensify efforts in relation to trafficking in human beings, including 
improvements in enforcement and the victim identification and referral mechanism. The Committee also recommended that the State enact legislation to provide victims of trafficking with rights to specialised assistance and legal protection regardless of nationality or immigration status. ${ }^{84}$

The Concluding Observations were welcomed by the Irish Network Against Racism (INAR) ${ }^{85}$ formerly ENAR Ireland, ${ }^{86}$ which had made a collective civil society submission to the Committee. ${ }^{87}$ The Immigrant Council of Ireland (ICI) also noted that most of the headline issues raised in its submission had been echoed in the Committee's concluding report. ${ }^{88}$

\subsubsection{Visit of UN High Commissioner for Refugees to Ireland}

The UN High Commissioner for Refugees, Filippo Grandi, made an official visit to Ireland on 11 July 2019. The High Commissioner commended Ireland's history regarding resettlement - Ireland first resettled Hungarian refugees in the 1950s, and Ireland was among the first six countries in Europe to establish a resettlement programme in 1998. He noted that between 2000 and 2018, some 3,000 refugees had been resettled to Ireland from almost 30 nationalities. He also welcomed the commitment in Ireland's development policy to the Global Compact on Refugees. He noted that: 'Ireland's support to developing countries which host nearly 90 percent of the world's refugees is an important component of the international community's refugee response. ${ }^{89} \mathrm{He}$ also addressed a number of domestic issues, including welcoming reforms in relation to reception conditions and expressing hope that waiting times for international protection determinations will continue to fall. ${ }^{90}$

\subsubsection{Global Refugee Forum, Geneva, December 2019}

Ireland made pledges in relation to resettlement under a new phase of the Irish Refugee Protection Programme at the UNHCR Global Refugee Forum in Geneva in December 2019 (see Section 4.4.2 for further detail regarding resettlement).

In addition, Ireland made a financial pledge of $€ 15.5$ million to UNHCR for 2020. In his address to the Forum, the Minister of State at the Department of Justice and

$84 \quad$ Ibid., paragraphs 41 and 42.

85 The Irish Network Against Racism is a national network of over 100 anti-racism civil society organisations which aims to work collectively to highlight and address racism in Ireland through the promotion and monitoring of Irish, EU and global trends and anti-racist initiatives. See WwW.inar.ie

86 Irish Network Against Racism (13 December 2019) 'The CERD Committee findings on Ireland published.' Available at: www.inar.ie.

87 See Sheridan, A. (2018). Annual Report on Migration and Asylum 2018: Ireland, pp. 22-23 for discussion of the submission.

88 Immigrant Council of Ireland (June 2020). Impact Report 2019, p. 34. Available at: www.immigrantcouncil.ie.

89 United Nations High Commissioner for Refugees (11 July 2019). 'UNHCR chief commends Irish solidarity with refugees and asks for further efforts to support those forced to flee', Press Release. Available at: www.unhcr.org.

90 Ibid. 
Equality reiterated Ireland's support to implement the Global Compact on Refugees. He stated that action to implement the compact should have three strands - first to support those in need, respecting the principle of furthest behind first; second to tackle the underlying causes of displacement, especially conflict; and thirdly to make countries places of welcome for those in need. ${ }^{91}$

UNHCR welcomed the pledges made by Ireland at the Forum, both by the State and by civil society. For example, it noted the commitment in Ireland's development strategy to the Global Compact on Refugees and to reach the international target for overseas development assistance of 0.7 per cent Gross National Income (GNI) by 2030 as economic circumstances permit, ${ }^{92}$ in accordance with the principle of 'furthest behind first' (see Section 2.3.4). In relation to the private sector, UNHCR noted that the Open Doors Initiative pledged to provide a skills development programme to 50 people, paid work placements for a minimum of 20 people and secure employment for at least 50 people. Six of Ireland's eight universities pledged a minimum of 104 scholarships over the academic year 2020$2021^{93}$

\subsubsection{International development strategy}

\section{A Better World - Ireland's policy for international development} Ireland's international development strategy A Better World ${ }^{94}$ was published in February 2019. This new strategy has a realigned focus on gender equality, climate action, good governance and combating poverty. It provides a framework for the achievement of Ireland's commitment to reach the international target for overseas development aid of 0.7 per cent GNI by 2030 as economic circumstances permit. In doing so, Ireland's investments are in accordance with the principle of reaching the 'furthest behind first. ${ }^{95}$

Under the heading of reducing humanitarian need, Ireland reaffirmed its commitment to follow through on the goals of the Global Compact on Refugees and the Global Compact on Safe, Orderly and Regular Migration. Following on from Ireland's co-facilitating of the New York Declaration in 2016, Ireland committed to

91 Department of Justice and Equality (17 December 2019). 'Ireland commits to a new Refugee Protection Programme', Press Release. Available at: www.justice.ie.

92 Government of Ireland (February 2019). A Better World. Available at: www.dfa.ie.

93 United Nations High Commissioner for Refugees (18 December 2019). 'Ireland pledges support for refugees at Global Refugee Forum', Press Release. Available at: www.unhcr.org.

94 Government of Ireland (February 2019). A Better World Available at: www.dfa.ie.

95 Department of Foreign Affairs and Trade (28 February 2019) 'A Better World, Ireland's New Policy for International Development', Press Release. Available at: www.dfa.ie. 
continue to be active in multilateral efforts to protect refugees and people on the move. ${ }^{96}$

\section{Strategy for Partnership with Small Island Developing States}

The Strategy for Partnership with Small Island Developing States was developed within the framework of $A$ Better World and was published in June 2019. ${ }^{97}$ The Small Island Developing States (SIDs) strategy focusses on how Ireland can collaborate better with SIDS counterparts to work effectively together as small islands, where there are shared interests in global outcomes, including in relation to 'working with the EU, development cooperation, especially on climate action, work with the diaspora and person-to-person linkages.'

One strong theme emerging from this Strategy is Ireland's commitment to sharing its experience of working with a diaspora. The Strategy commits to:

share Irish experience of engaging with our diaspora with SIDS, in particular how an active diaspora can increase the influence and convening potential of a small state, as well as its potential for positively influencing investment. ${ }^{98}$

\section{Global Ireland - Ireland's Strategy for Africa to 2025} Ireland's new Africa strategy Global Ireland - Ireland's Strategy for Africa to 2025 was launched in November 2019. The Strategy proposes to strengthen political partnership with Africa and boost trade and investment. It provides that the number of places on the Africa Fellows Scheme, which brings postgraduate students from Africa to Ireland, will be doubled by 2025. The Strategy also underpins Ireland's commitment to working towards a strengthened EU-Africa partnership. $^{99}$

The Strategy commits to supporting multilateral efforts to protect refugees and people on the move in Africa, including through implementation of the Global Compacts. It also commits to increasing Ireland's:

capacity to develop regional approaches, in areas such as the Horn of Africa and the Sahel, to cross-border issues such as conflict and fragility, climate change mitigation and adaptation, disaster risk reduction, and

96 Government of Ireland (February 2019) A Better World, Ireland's Policy for International Development, pp. 17-18. Available at: www.irishaid.ie.

97 Department of Foreign Affairs and Trade (10 June 2019) 'Tánaiste launches new strategy for Ireland's partnership with Small Island Developing States', Press Release. Available at: www.dfa.ie.

98 Government of Ireland (June 2019) Strategy for Partnership with Small Island Developing States, p. 14. Available at: www.dfa.ie.

99 Department of Foreign Affairs and Trade (27 November 2019) 'Launch of the Government's New Africa Strategy: Global Ireland: Ireland's Strategy for Africa', Press Release. Available at: www.dfa.ie. 
migration management, including through working closely with EU

partners. $^{100}$

\subsection{POPULATION AND MIGRATION ESTIMATES}

\section{FIGURE 2.1 GROSS AND NET MIGRATION, IRELAND, 2010-APRIL 2020}

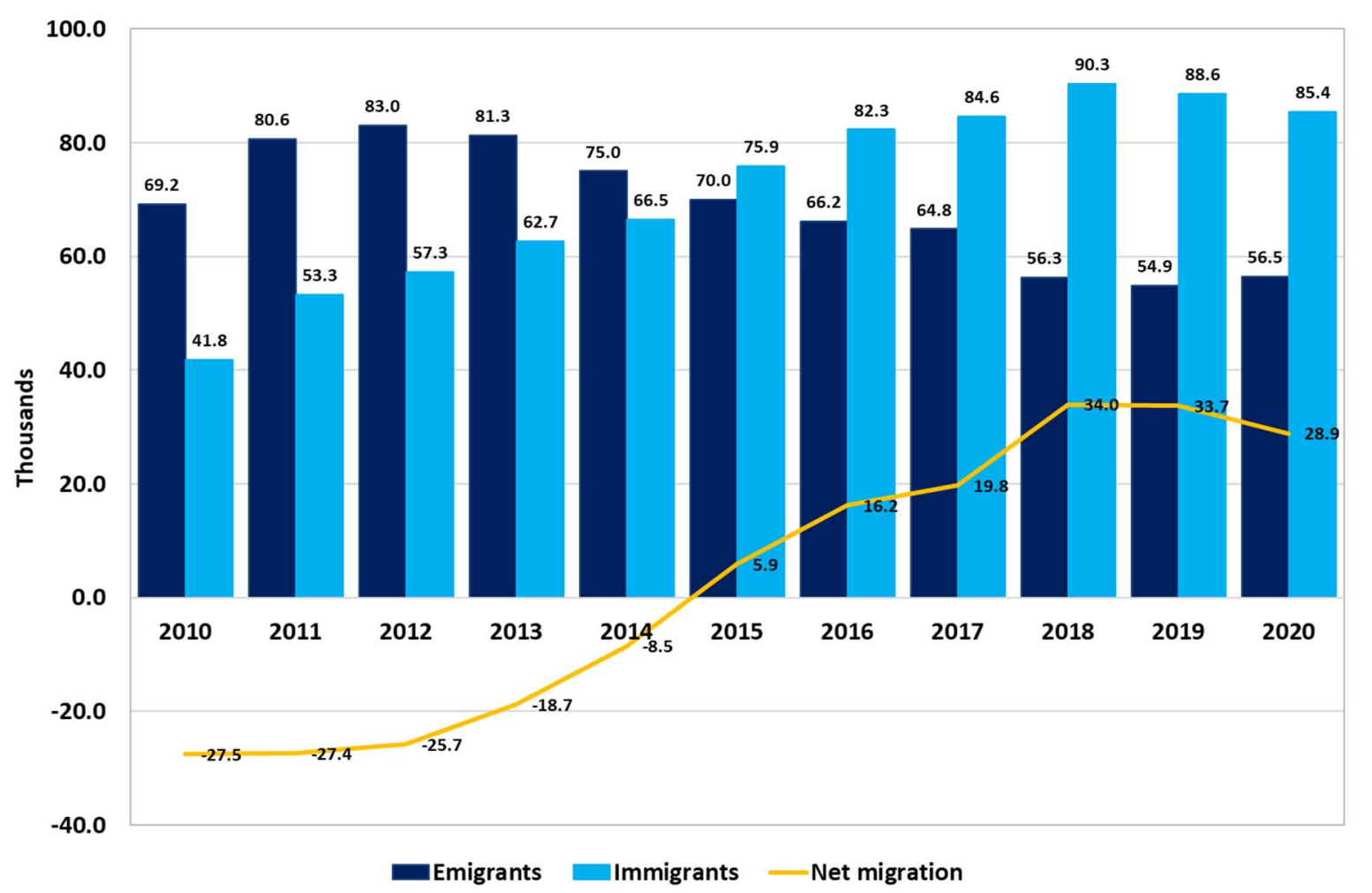

Population and Migration Estimates, CSO.

Figure 2.1 shows gross and net migration for Ireland from 2010 to April 2020. Total net inward migration decreased slightly to 28,900 from 33,700 in April 2019. NonIrish nationals from outside the EU continued to display strong migration flows, accounting for 30,400 (36\%) of total immigrants (see Figure 2.2) and 11,400 (20\%) of total emigrants (see Figure 2.3). This resulted in a total net inward migration figure for non-EU nationals of 19,000.

100 Government of Ireland (November 2019) Global Ireland - Ireland's Strategy for Africa to 2025, p. 13. Available at: www.dfa.ie. 


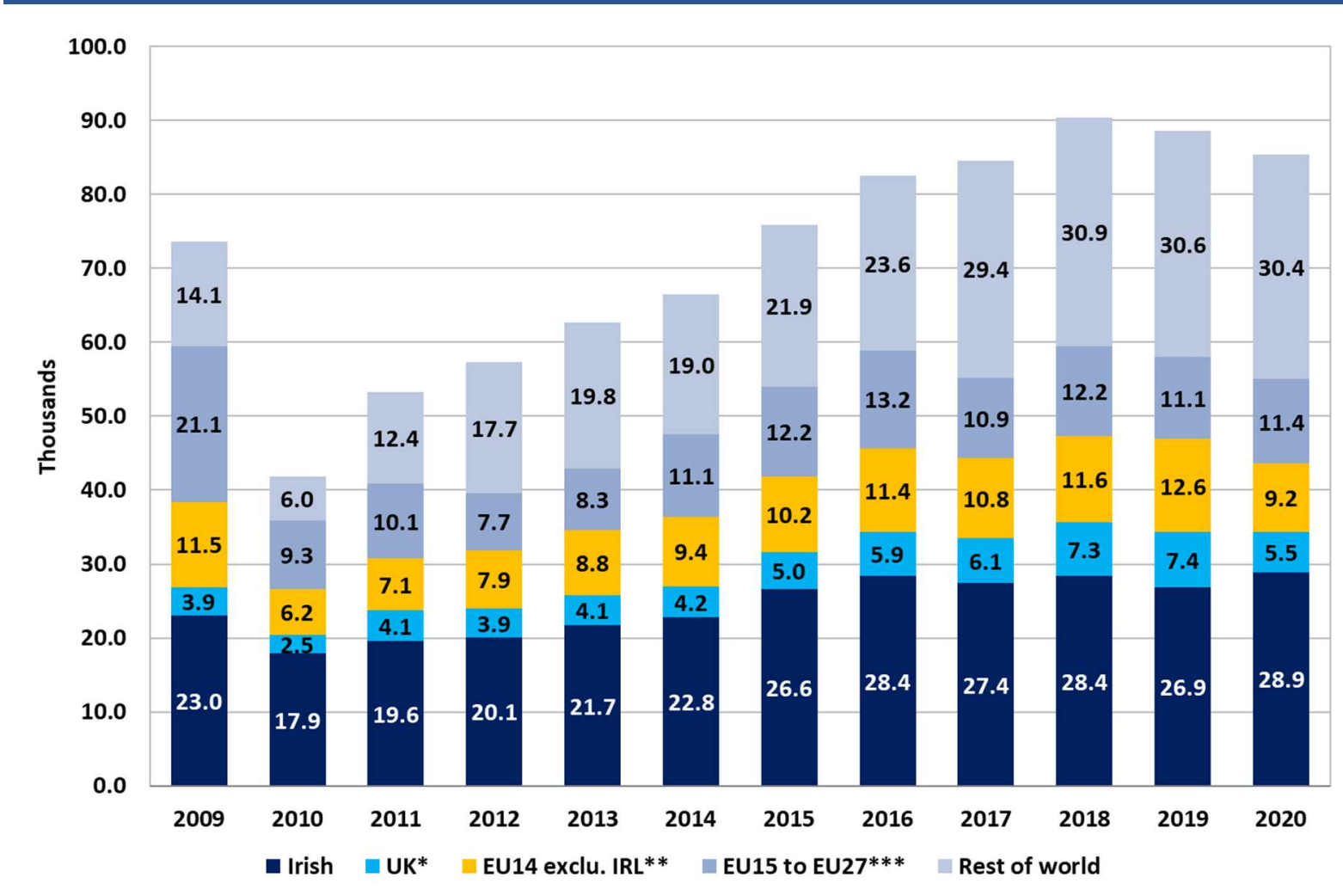

Source: $\quad$ Population and Migration Estimates, CSO.

Notes: $\quad *$ In light of the UK leaving the EU with effect from 1 February 2020, EU labelling has been updated. ${ }^{* *}$ Rest of EU14 excl. IRL: countries before enlargement on 1 May 2004 (i.e. Austria, Belgium, Denmark, Finland, France, Germany, Greece, Italy, Luxembourg, Netherlands, Spain, Sweden, Portugal). ***EU15 to 27: 10 countries that joined the EU on 1 May 2004 (i.e. Cyprus, Czech Republic, Estonia, Hungary, Latvia, Lithuania, Malta, Poland, Slovakia, Slovenia), along with Bulgaria and Romania, which joined on 1 January 2007, and Croatia, which joined on 1 July 2013.

As shown in Figure 2.2, the estimated total number of immigrants to Ireland decreased slightly year-on-year to 85,400 in April 2020 from 88,600 in April 2019, a decrease of 3.6 per cent. The largest group of immigrants during this period was non-EU nationals, showing a small decrease of 200 over 2019. Immigration by UK nationals decreased by 1,900 over 2019. As in the year ending April 2019, non-EU nationals remained the largest immigrant group. There was an increase of 2,000 in returning Irish nationals, from 26,900 in 2019 to 28,900 in the year ending April 2020. 


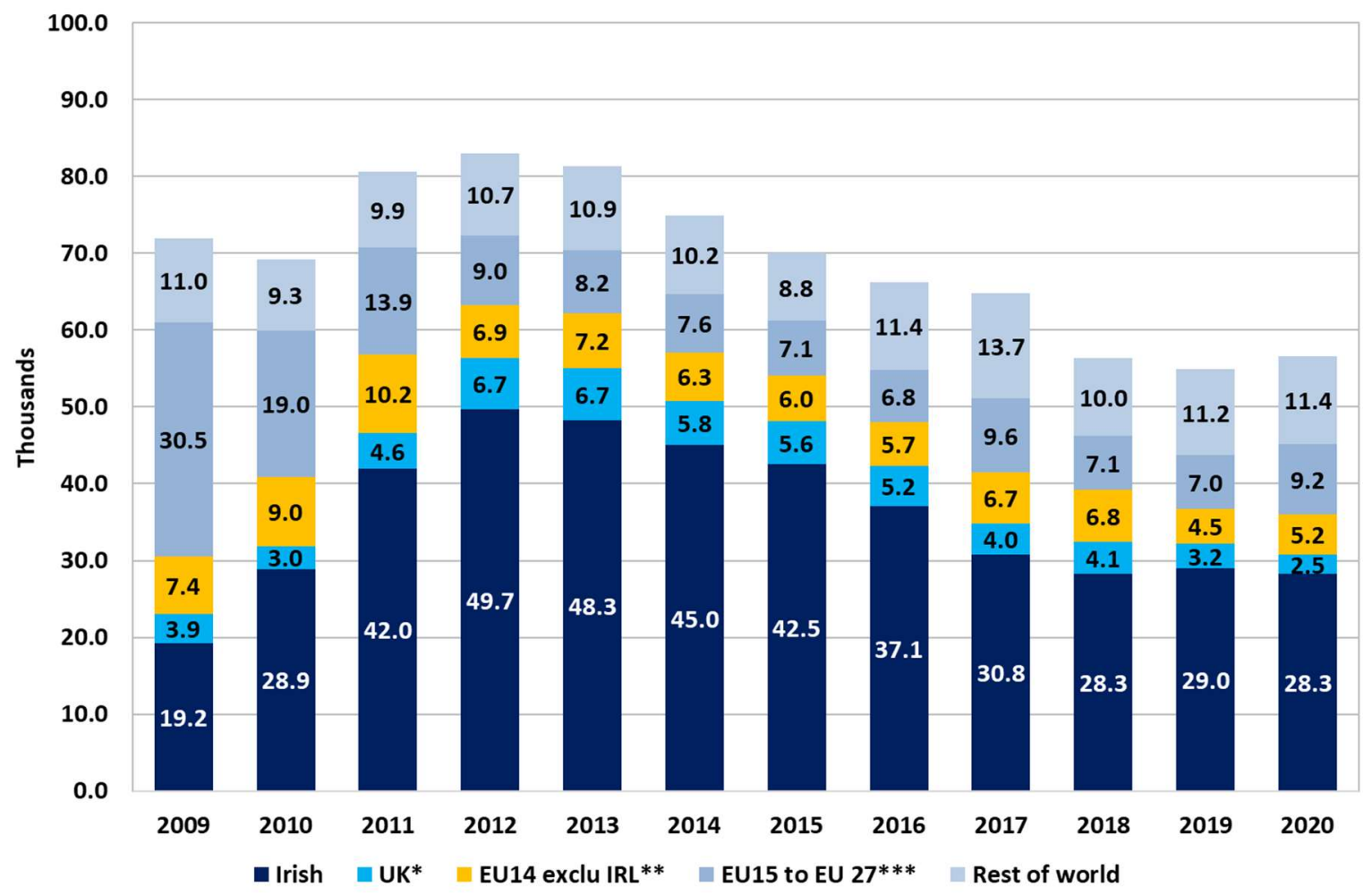

Source: $\quad$ Population and Migration Estimates, CSO.

Notes: $\quad *$ In light of the UK leaving the EU with effect from 1 February 2020, EU labelling has been updated. ${ }^{* *}$ Rest of EU14 excl. IRL: countries before enlargement on 1 May 2004 (i.e. Austria, Belgium, Denmark, Finland, France, Germany, Greece, Italy, Luxembourg, Netherlands, Spain, Sweden, Portugal). ***EU15 to 27: 10 countries that joined the EU on 1 May 2004 (i.e. Cyprus, Czech Republic, Estonia, Hungary, Latvia, Lithuania, Malta, Poland, Slovakia, Slovenia), along with Bulgaria and Romania, which joined on 1 January 2007, and Croatia, which joined on 1 July 2013.

As Figure 2.3 shows, there was an overall increase of 3.1 per cent in the numbers emigrating from Ireland in the year ending April 2020, from 54,900 in 2019 to 56,600 at end April 2020. The largest group was non-EU nationals: the number of non-EU nationals emigrating increased by 200 from 11,200 in the year ending April 2019 to 11,400 in the year ending April 2020. Emigration by Irish nationals again decreased slightly, having reached its peak at 49,700 in 2012. 


\section{CHAPTER 3}

\section{Legal migration}

\subsection{RESIDENCE PERMIT STATISTICS}

According to Eurostat, a total of 168,297 residence permits were valid in Ireland as of 31 December 2019. This represented an increase of 18.2 per cent from a total of 142,286 at the end of 2018. The category breakdown is set out in Table 3.1.

Source: $\quad$ Eurostat migr_resvalid. Data extracted 21 October 2020

According to Eurostat, a total of 59,278 first residence permits were granted in Ireland in 2019. Table 3.2 shows the breakdown of reasons between work, study, family reasons and other, and Ireland's percentage share and ranking in relation to the total first permissions granted in these categories across the EU-28.

TABLE 3.2 FIRST RESIDENCE PERMITS GRANTED IN IRELAND AND EU-28 MEMBER STATES IN 2019

\begin{tabular}{|l|c|c|c|c|}
\hline Category & Ireland & EU-28 & $\begin{array}{c}\text { Ireland \% of EU } \\
\text { total }\end{array}$ & $\begin{array}{c}\text { Ireland ranking in } \\
\text { EU-28 MS (from } \\
\text { highest) }\end{array}$ \\
\hline $\begin{array}{l}\text { Remunerated } \\
\text { reasons }\end{array}$ & 12,049 & $1,197,308$ & 1 & 17 \\
\hline Study & 34,735 & 399,912 & 8.68 & 4 \\
\hline Family reasons & 3,671 & 810,009 & 0.45 & 21 \\
\hline Other & 8,823 & 545,911 & 1.6 & 12 \\
\hline Total & 59,278 & $2,953,140$ & 2 & 12 \\
\hline
\end{tabular}

Source: Eurostat migr_resfirst Data extracted 21 October 2020. 


\subsection{ECONOMIC MIGRATION}

\subsubsection{Employment permit statistics}

A total of 16,383 employment permits were issued during 2019: 14,163 new permits and 2,220 renewals, an increase of 22 per cent over the 2018 total of 13,398 employment permits. As for 2018, the top nationality was India (with 5,373 permits). The top three sectors were the service industry, medical and nursing, and industry. ${ }^{101}$

\subsubsection{Legislation}

Three sets of regulations in relation to employment permits were passed during 2019. These regulations made changes to the employment permits occupations lists to adjust for skills needs and certain other amendments to the Employment Permits Regulations 2017. The Critical Skills Occupations List (CSOL) includes 'employments in respect of which there is a shortage in respect of qualifications, experience or skills which are required for the proper functioning of the economy'. ${ }^{102}$ Occupations on the CSOL are in the main professional positions in medicine, ICT, sciences, and finance and business and are eligible for Critical Skills Employment Permits. The IOL gives 'employments in respect of which an employment permit shall not be granted' ${ }^{103}$ Occupations on the IOL are generally lower skilled and are deemed ineligible for the grant of employment permits as the evidence is that sufficient resources are available within Ireland/European Economic Area (EEA).

\section{Amendments to the CSOL}

Following the twice-yearly reviews in 2019 of the employment permit CSOL and IOL, the following occupations were added to the CSOL via the Employment Permits (Amendment) Regulations 2019 and the Employment Permits (Amendment) (No. 3) Regulations 2019:104

- civil engineers;

- quantity surveyors;

- construction project managers;

- mechanical and electrical engineers with BIM expertise;

101 Department of Business, Enterprise and Innovation, Employment Permits by Nationality 2019. Available at: www.dbei.gov.ie.

See 'Critical Skills Occupations List' at www.dbei.gov.ie.

103 See 'Ineligible List of Occupations for Employment Permits' at www.dbei.gov.ie.

104 S.I. No. 138 of 2019 and S.I. No. 633 of 2019. 
- high-performance directors and coaches for high-level sports organisations (national or high-profile sports organisations engaging in international competition);

- site managers;

- structural/site engineers;

- mechanical engineers;

- electrical engineers;

- setting-out engineers;

- façade designers;

- architects;

- architectural technologists.

\section{Amendments to the IOL}

The Employment Permits (Amendment) Regulations $2019^{105}$ removed certain lowand medium-skilled occupations (mainly in the construction and metal forming and welding trades) from the IOL.

Some of these occupations - transport and distribution clerks (300), plasterers and bricklayers (250) - were subject to quotas.

In addition, quotas were adjusted in relation to certain occupations. The Employment Permits (Amendment) (No. 2) Regulations $2019^{106}$ increased the quotas, which had been established in 2018, for certain occupations in the agrifood area (meat boners and dairy farm assistants). The maximum limit of General Employment Permits that could be granted was adjusted to 101 in respect of dairy farm assistants and to $\mathbf{3 0 0}$ for meat boners.

The Employment Permits (Amendment) (No. 3) Regulations $2019^{107}$ changed the regulations to provide for the removal of additional construction occupations and all grades of chef from the IOL and adjusted quotas in respect of heavy goods vehicle drivers and meat processing operatives. ${ }^{108}$

\section{Remuneration thresholds}

The Employment Permits (Amendment) (No. 2) Regulations 2019, provided for 
increases in remuneration thresholds for Critical Skills Employment Permit holders, applicable from 1 January 2020, to begin the realignment of the remuneration threshold with average annual earnings. The threshold increases are:

- for occupations on the CSOL, from $€ 30,000$ to $€ 32,000$;

- for other occupations eligible for an employment permit not on the IOL and with the necessary experience, from $€ 60,000$ to $€ 64,000$. ${ }^{109}$

\section{Labour market needs test}

The Employment Permits (Amendment) (No. 2) Regulations 2019 also provided for the extension of the duration of the labour market needs test required to be undertaken within Ireland and across the EEA from two weeks to four weeks, applicable from 1 January 2020.

\subsubsection{General Scheme of an Employment Permits (Consolidation and Amendment) Bill}

The General Scheme of the Employment Permits (Consolidation and Amendment Bill) was launched in October 2019,110 and a public consultation phase was launched in December 2019. ${ }^{111}$ The Bill includes the following proposed changes to be introduced in employment permits legislation.

\section{Seasonal Employment Permit}

As reported for 2018, the Department of Business, Enterprise and Innovation undertook a review of economic migration policy in 2018. One of the recommendations of the review was the introduction of a Seasonal Employment Permit to facilitate certain categories of short-term workers. The Review found that there was a demand for seasonal contracts of six to nine months for lower skilled workers.

The Seasonal Employment Permit will be introduced by way of the Employment Permits (Consolidation and Amendment) Bill. The proposal for a seasonal permit would provide for a non-EEA national 'to work in the Irish State temporarily while retaining a legal domicile in a third country, for the purposes of employment in a sector of seasonal activity'. ${ }^{112}$

109 Department of Business, Enterprise and Innovation (20 November 2019) 'Early notice of changes to the operation of the Employment Permits system'. Available at: www.dbei.gov.ie.

110 Correspondence with Department of Business, Enterprise and Innovation, February 2020.

111 Department of Business, Enterprise and Innovation (3 December 2019) 'Public Consultation on the General Scheme of an Employment Permits (Consolidation and Amendment) Bill', Press Release. Available at: www.dbei.gov.ie.

112 Department of Business, Enterprise and Innovation (8 November 2019) 'Information note on the General Scheme of an Employment Permits (Consolidation and Amendment) Bill', p. 3. Available at: www.dbei.gov.ie. 
According to the Department of Business, Enterprise and Innovation:

The development of criteria for this permit will involve an examination of seasonal permits in other jurisdictions and will address key issues such as: sectors which might avail of the permit type; seasonal duration; remuneration; conditionality; employer commitments; benefits and supports; limiting the permit to certain sectors and occupations plus any potential risks. ${ }^{113}$

The Migrants Rights Centre of Ireland (MRCl) referred to previously expressed concerns in relation to the proposals for a seasonal employment permit due to difficulties in monitoring these types of permits and that workers may be more vulnerable to exploitation. ${ }^{114,115}$

\section{Special Circumstances Employment Permit}

The General Scheme of an Employment Permits (Consolidation and Amendment) Bill also makes provision for the introduction of a Special Circumstances Employment Permit. This would cover an occasional need that may arise to grant an employment permit that does not comply with standard criteria but would nevertheless be beneficial for the social or economic development of the State. ${ }^{116}$

\section{Other amendments to employment permit rules}

The General Scheme of an Employment Permits (Consolidation and Amendment) Bill proposes certain technical amendments to rules surrounding employment permits. Certain requirements will be removed from primary legislation to a legal basis in secondary legislation; for example, operational features of the Labour Market Needs Test (requirement for advertising). ${ }^{117}$

Other amendments proposed include to:

- simplify the administration of entry to the State of persons undertaking duties in the State on the basis of international free trade agreements and provide for bilateral agreements;

- allow for the refund of fees where the employment permit cannot be taken up in prescribed circumstances;

Ibid., p. 4.

Correspondence with $\mathrm{MRCl}$, November 2020.

Migrant Rights Centre of Ireland (2018) 'MRCI Submission to Consultation on Proposed Guiding Principles to frame the State's Economic Migration Policy', p. 10. Available at: www.mrci.ie.

116 Department of Business, Enterprise and Innovation (8 November 2019) 'Information note on the General Scheme of an Employment Permits (Consolidation and Amendment) Bill', Available at: www.dbei.gov.ie; Correspondence with Department of Business, Enterprise and Innovation, February 2020.

117 Department of Business, Enterprise and Innovation (8 November 2019) 'Information note on the General Scheme of an Employment Permits (Consolidation and Amendment) Bill'. Available at: www.dbei.gov.ie. 
- allow for the revocation of an employment permit where the permit holder doesn't take up the employment within a prescribed period;

- allow for conditionality to be prescribed in Regulations such as employer commitments to the provision of training, knowledge transfer, process innovation or specified supports such as accommodation, health insurance etc. ${ }^{118}$

\section{Brexit}

UK nationals will not be required to hold employment permits in Ireland following Brexit. This flows from the Aliens (Exemption) Order $1999^{119}$ which exempts UK nationals from the application of immigration controls under the Aliens Act $1935 .{ }^{120}$

\subsubsection{Changes to immigration arrangements for spouses and de facto partners of Critical Skills Employment Permit Holders}

Changes to immigration arrangements for spouses and de facto partners of Critical Skills Employment Permit Holders and researchers with a Hosting Agreement under Directive 2005/71/EC were announced on 6 March 2019. The new arrangements provided for immediate and full access to the labour market for spouses and de facto partners of Critical Skills Employment Permit Holders. From 6 March 2019, the Irish Naturalisation and Immigration Service (INIS) granted eligible spouses and de facto partners immigration permission on Stamp 1G, with access to the labour market without the requirement to obtain an employment permit. ${ }^{121}$ The Migrant Rights Centre of Ireland (MRCl) has commented that this access was granted after a successful grassroots campaign on the issue. ${ }^{122}$

The following summarises the conditions associated with this immigration permission.

- Holder is permitted to work in the State without the requirement to obtain a work permit.

- Holder is not permitted to establish or operate a business.

- Holder is not permitted to be self-employed.

Ibid.

S.I. No. 97 of 1999.

Correspondence with Department of Business, Enterprise and Innovation, October 2020.

Department of Business, Enterprise and Innovation (6 March 2019) 'Ministers Humphreys and Flanagan announce change to immigration arrangements for spouses and partners of Critical Skills Employment Permit Holders and Researchers under a Hosting Agreement', Latest updates and developments in respect to Employment Permits. Available at: www.dbei.gov.ie; Department of Justice and Equality (6 March 2019) 'Important Notice: Update to the INIS Non-EEA Family Reunification Policy Document'. Available at: www.inis.gov.ie. 
- Renewal of the Stamp $1 \mathrm{G}$ registration should be applied for annually, and after five years on a Stamp 1G, application for a Stamp 4 is permitted. Stamp 4 also permits the holder to establish or operate a business.

- Periods spent on Stamp $1 G$ are considered as reckonable residence for the purpose of making an application for citizenship/naturalisation. ${ }^{123}$

Dependants of Critical Skills Employment Permit holders will be provided for under the General Scheme. ${ }^{124}$

\subsubsection{Atypical Working Scheme}

During 2019, a total of 3,347 applications were approved under the Atypical Working Scheme, which provides for short-term employment contracts in the State due to the short-term nature of the contract (i.e. between 15 and 90 days ${ }^{125}$ ) and that are not facilitated by the employment permit process. ${ }^{126}$

Permissions granted were largely in the medical sector - non-EEA national nurses undertaking the adaptation process prior to the application for an employment and non-EEA national locum doctors. Additionally, a significant number of permissions were granted to engineers and computer skills specialists.

From November 2019, certain amendments were announced to the Atypical Working Scheme regarding locum doctors working in the primary care sector (general practice). These changes related to the cooling-off period before the locum doctor can make a new application to work in the State, and provisions regarding intermittent travel outside the State. A permission under the Scheme is granted for a period of 90 consecutive days - travel outside the State is permitted for up to 14 days during this 90-day period. The doctor must leave the State on expiry of the 90-day period and at least 30 days must elapse before the doctor can re-enter the State on a new permission under the Scheme as a locum doctor in the primary care sector. The new application can be made as soon as the doctor leaves the State. ${ }^{127}$

As reported for previous years, the Atypical Working Scheme was expanded to include permission for non-EEA workers to work in the Irish fishing fleet in December 2015. A total of 76 applications in respect of non-EEA national workers

\footnotetext{
Department of Justice and Equality, Permissions, Stamps and Conditions. Available at: www.inis.gov.ie. Correspondence with Department of Business, Enterprise and Innovation, February 2020.

Some atypical permissions may be granted for periods greater than 90 days.

Correspondence with Atypical, Business and Start-up Unit, Immigration Service Delivery, Department of Justice and Equality, February 2020.

127 Department of Justice and Equality (2 December 2019) 'Doctors providing locum service in the primary care sector (General Practice)'. Available at: www.inis.gov.ie.
} 
for the Irish fishing fleet were approved in 2019. An additional 137 permissions were renewed. ${ }^{128}$

For further information regarding non-EEA workers in the Irish fishing fleet, see Chapter 8.

\subsection{PRE-CLEARANCE SCHEMES}

\section{Immigration preclearance scheme for non-EEA national de facto partner of Irish citizens}

As reported for 2018, the Department of Justice and Equality (INIS) introduced immigration preclearance schemes for ministers of religion and lay volunteers. Immigration preclearance was extended in 2019 to non-EEA national de facto partners of Irish citizens from both visa-required and non-visa-required countries. Under the new procedure, non-EEA national de facto partners of Irish citizens can apply for their permission to reside in Ireland prior to arrival in the State and can register with the immigration authorities and have access to the labour market immediately on arrival. Under previous arrangements, the application for residence permission could only commence on arrival in the State, without access to the labour market while the application was pending.

The requirement to obtain a preclearance letter to travel to Ireland for this category applied from 1 November 2019. The de facto partner of an Irish national must apply to the Department of Justice and Equality for the letter. Dependent children can be included in the application. Applicants from visa-required countries will also need to apply for a visa.

The permission may be granted to non-EEA nationals who have an Irish citizen life partner and wish to live with them in Ireland. The permission is conditional on the relationship and if the relationship ends, the permission ends.

The purpose of the new arrangements, according to the Minister for Justice and Equality, is to 'ensure that there is a clear and simple path available for those who want to return to Ireland with their de facto partners'. It addresses one of the recommendations in a report by consultancy firm Indecon, Addressing challenges faced by returning Irish emigrants, and is part of the ongoing INIS Customer Service Improvement Plan.

128 Correspondence with Atypical, Business and Start-up Unit, Immigration Service Delivery, Department of Justice and Equality, February 2020. 
A de facto partner is defined as follows: 'For immigration purposes, a person may be considered the De Facto Partner, opposite or same sex, of another person if:

- they have a mutual commitment to a shared life to the exclusion of all others akin to a marriage or civil partnership in practice though not in law and

- the relationship between them is genuine and continuing and

- they live together or do not live separately and apart on a permanent basis and

- they are not related by family. ${ }^{\prime 29}$

\subsection{IMMIGRANT INVESTORS AND ENTREPRENEURS}

\subsubsection{Immigrant Investor Programme}

Under the Immigrant Investor Programme (IIP), ${ }^{130}$ a total of 396 applications were received in 2019, over five application windows. A total of 294 applications were approved in 2019 with a total investment value of over $€ 250$ million. ${ }^{131}$

As reported for 2018, the INIS published terms of reference for an external review of the IIP on 5 November 2018. ${ }^{132}$ The external review was progressed during 2019 and was expected to be finalised in the first quarter of $2020 .{ }^{133}$

\subsubsection{Start-up Entrepreneur Programme}

A total of 26 applications were received and 10 were approved under the Start-up Entrepreneur Programme (STEP) ${ }^{134}$ during 2019. ${ }^{135}$

The Department of Justice and Equality began an internal review of the STEP during 2018, as a response to the low number of applications. During 2019, the Department consulted stakeholders in the start-up and innovation sector and found that awareness of the scheme was low; it identified other challenges for

129 Department of Justice and Equality (19 August 2019) 'New preclearance process to be introduced to help non-EEA de facto partners of Irish citizens to live and work in Ireland', Press Release. Available at: www.inis.gov.ie.

130 The Immigrant Investor Programme (IIP) was introduced by the Irish Government in 2012 to encourage inward investment for the creation of business and employment opportunities in the State. The IIP is designed to encourage investors and business professionals from outside the EEA to avail of opportunities for investing and locating their business interests in Ireland and acquire a secure residency status in Ireland (PQ 19290/19). Available at: www.justice.ie.

131 Correspondence with Atypical, Business and Start-up Unit, Immigration Service Delivery, Department of Justice and Equality, February 2020.

132 Department of Justice and Equality (5 November 2018) 'Immigrant Investor Programme - Terms of Reference for External Review'. Available at: www.inis.gov.ie.

133 See 'Investors and Entrepreneurs' page, updated 23 December 2019. Available at: www.inis.gov.ie.

134 The STEP was established in 2012 as a way for entrepreneurs with an innovative idea to apply for a residence permission in Ireland (PQ 8647/19).

135 Correspondence with Atypical, Business and Start-up Unit, Immigration Service Delivery, Department of Justice and Equality, February 2020. 
innovators wishing to relocate including the lack of a network in Ireland and access to appropriate funding. As a result of this review, the Department plans to further develop the pre-application phase that was originally initiated in $2014 .{ }^{136}$ It is envisaged that start-up founders will approach an Irish accelerator with their business idea and apply to attend a full-time programme and for equity funding in order to become 'investor ready'. Upon securing a place in such a programme, the start-up founder can then apply for a 12-month residence permission under STEP (stamp 4) in order to attend the programme. If the duration of the programme is less than 12 months, the balance of time for that residence permission can be spent further developing the business idea. Prior to that permission expiring they can then apply for the normal STEP residence permission (stamp 4 for two years).

In circumstances where the start-up already exists and wishes to apply to STEP, those businesses can bypass the one-year accelerator programme and apply straight for the two-year STEP permission. ${ }^{137,138}$

\subsection{INTERNATIONAL STUDENTS}

\subsubsection{International Education Mark}

As reported in previous years, the International Education Strategy for Ireland 2016-2020 was published in October 2016.

One of the Strategy's commitments related to the development of an International Education Mark (IEM), which was originally planned to come on stream in 2016. ${ }^{139}$ The International Education Strategy committed as a strategic priority to 'Ensure Ireland's International Education offering is underpinned by a robust regulatory environment in order to safeguard Ireland's reputation internationally. The International Education Mark will be developed and legislation enacted to enhance our quality framework for international education in this regard. ${ }^{140}$

The Irish Government approved a draft outline of legislation to include provision for the IEM in May 2017. The Qualifications and Quality Assurance (Education and Training) (Amendment) Bill 2018 passed both houses of the Oireachtas on 11 July 2019 and the Qualifications and Quality Assurance (Education and Training)

136 The 2014 pre-application phase involved an immigration permission of up to 12 months to attend an incubator or innovation bootcamp in order to assist in preparing a strong application for STEP.

137 It would have to be shown that the business has been trading for one year and has established a customer for its product.

138 McNamara, F. and E. Quinn (January 2020) Migratory pathways to Ireland for start-ups and innovative entrepreneurs, pp. 14-15. Available at: www.emn.ie and www.esri.ie.

139 Reform of the International Education Sector and Student Immigration System Government Policy Statement, May 2015, p. 1. Available at: www.inis.gov.ie.

140 Department of Education and Skills (October 2016) International Education Strategy for Ireland 2016-2020, p. 42. Available at: www.education.ie. 
(Amendment) Act 2019 (No. 32 of 2019) was subsequently signed into law. ${ }^{141}$ The Department of Education and Skills noted:

The introduction of the International Education Mark is a key element of the Government's International Education Strategy, which will see the value of this sector grow by one third to $€ 2.1$ billion over its lifetime. ${ }^{142}$

Only some sections of the Qualifications and Quality Assurance (Education and Training) (Amendment) Act 2019 have been commenced. The IEM was not implemented during 2019. Therefore, the lifespan of the Interim List of Eligible Programmes (ILEP), which gives the eligible educational programmes for immigration purposes, was extended further during 2019.

\subsubsection{Interim List of Eligible Programmes}

In September 2019, foundation programmes were added to the ILEP. The original policy envisaged that foundation programmes would be dealt with outside the ILEP structure. However, as a result of the extended lifespan of the ILEP, it was considered necessary to include foundation programmes. Another factor that influenced the inclusion of foundation programmes was that Quality and Qualifications Ireland (QQI) published awards standards for pre-higher education foundation awards for international students ${ }^{143}$ following the introduction of the ILEP. ${ }^{144}$

\subsubsection{Online immigration registration renewal system for students}

A new online immigration registration renewal system for third-level non-EEAnational students resident in the Dublin area was announced in July 2019. From 26 August 2019, third-level students, living in Dublin and progressing to the second or subsequent year of a degree-level course, could renew their registration online. First-year students were still required to register in person at the Dublin Registration Office. The new arrangements did not apply to English language students.

141 Department of Education and Skills (11 July 2019) 'Qualifications and Quality Assurance (Education and Training) (Amendment) Bill 2018 passes both Houses of the Oireachtas', Press Release. Available at: www.education.ie.

142 Ibid.

143 https://www.qqi.ie/Publications/Publications/IFY\%20Standards\%20\%20201115-LR3.pdf.

144 Department of Justice and Equality and Department of Education and Skills (2019) 'Department of Justice and Equality Irish Naturalisation and Immigration Service (INIS) Interim List of Eligible Programmes for Student Immigration Permission Arrangements Applying to Foundation Programmes from 9 September 2019', p. 2, Information Note. Available at: www.inis.gov.ie. 
Students living outside Dublin were still required to renew their registration in person with their nearest Garda District office. ${ }^{145}$

\subsubsection{Research}

EMN Ireland published Attracting and retaining international higher education students: Ireland in May 2019. This study examined policy, law and practice relating to international students undertaking a programme of higher education in Ireland. In particular, it looked at measures to attract non-EEA students to Ireland and to retain such students following the completion of their studies. The study focused on recent developments in policy on the internationalisation of higher education and changes to the student immigration framework that took place between 2012 and 2018.

The study found that immigration of non-EEA nationals for the purposes of higherlevel study in Ireland grew by 45 per cent between 2013, when 9,325 first residence permits were issued to students, and 2017, when 13,519 such permits were issued. ${ }^{146}$

\subsection{CASELAW: EU TREATY RIGHTS ${ }^{147}$}

During 2019, the Court of Appeal gave a number of judgments in test cases regarding EU Treaty Rights applications. In the joined cases of $V K V$ Minister for Justice and Khan v Minister for Justice [2019] IECA 232 the Court of Appeal considered the test to be applied in assessing the meaning of 'qualifying family member' in the Citizens' Directive the standard to be applied in assessing dependency and the degree of scrutiny to be applied by the Minister in assessing those applications.

Baker J giving the judgment of the court confirmed that the test for dependence is one of EU law and an applicant must show, in the light of his financial and social conditions, a real and not temporary dependence on a Union citizen. The financial needs must be for basic or essential needs of a material nature without which a person could not support himself or herself. A person does not have to be wholly dependent on the Union citizen to meet essential needs, but the needs actually met must be essential to life and the financial support must be more than merely 'welcome', to use the language of Edwards $\mathrm{J}$ in $M v$ Minister for Justice, Equality and Law Reform [2009] IEHC 500.

145 Department of Justice and Equality (29 July 2019) 'Minister Flanagan announces new immigration registration renewal system for 3rd level students', Press Release. Available at: www.inis.gov.ie.

146 Groarke S and C Durst (May 2019) Attracting and retaining international higher education students: Ireland Available at: www.emn.ie and www.esri.ie.

147 Case analysis provided by EMN legal consultant. 
Baker J confirmed that the concept of dependence is to be interpreted broadly and in the light of the perceived benefit of family unity and the principles of freedom of movement. For the purposes of making the assessment, the proofs required, although remaining in the discretion of Member States, must not impose an excessively burdensome obligation on an applicant or impose too heavy a burden of proof or an excessive demand for the production of documentary evidence. The requested Member State must justify the refusal, and therefore must give reasons which explain and justify the refusal. Baker $J$ noted that when the case law identifies the requirement that the dependence be 'real', this means that the dependence must be something of substance, support that is more than just fleeting or trifling, and support that must be proven, concrete, and factually established. However, it was held that an applicant does not have to establish that without that real or material assistance he or she would be living in conditions equivalent to destitution. Dependence may be for something more than help to sustain life at a subsistence level and no more.

Baker J concluded that what is to be assessed is whether a family member has a real need for financial assistance and not whether that person could survive without it; it is a test of the facts and not an interrogation of the reasons for the support. Applying this test to the facts of the instant case, Baker J upheld the decision of MacEochaidh $\mathrm{J}$ in VK and Faherty $\mathrm{J}$ in Khan.

Subhan and Ali v Minister for Justice [2019] IECA 330 concerned the test for determining whether a family member is a 'member of the household' for the purposes of the Citizens' Directive. The Court of Appeal upheld the decision of the High Court that a person who cohabits or lives under the same roof as a Union citizen is not, merely by reason of that cohabitation, to be considered a member of the Union citizen's household.

Baker J rejected the appellants' contention that the High Court judge had impermissibly posited a requirement that there be identified a "head of the household', and noted that the High Court judge had expressly stated that what has to be identified is the household of the Union citizen and thereafter whether the applicant for permission to enter and remain is a member of that household. The centrality of the Union citizen is what is in issue, not whether the Union citizen heads that group or governs the living arrangements within the dwelling.

Baker J held that the key task of the decision-maker was to ascertain whether the cohabitation or co-living arrangements are more than merely convenient, and whether the non-Union citizen family member is part of a cohesive, long-term, coherent and single unit which might generally be called a 'household'. With that in mind, the living arrangements are not to be viewed with a bird's-eye view of a single moment in time but must rather have some regard to the durability of the 
cohabitation, and also of what future intentions can be objectively presumed regarding the continued existence of the household.

The court noted that it may be more useful to consider the notion of household by reference to what it is not: persons living under the same roof are not necessarily members of the same household and they may well be what we colloquially call housemates. An element of sharing that is necessary in a household may well be met in that the persons living together may agree on a distribution of household tasks and a proportionate contribution towards household expenses. But because, for the purpose of the Citizens' Directive, one must focus on the living arrangements of the Union citizen, the members of the household of the Union citizen must, on the facts, be persons who are in some way central to his or her family life, that those family members are an integral part of the core family life of the Union citizen, and are envisaged to continue to be such for the foreseeable or reasonably foreseeable future. The defining characteristic is that the members of the group intend the co-living arrangement to continue indefinitely, that the link has become the norm and is envisaged as ongoing and is part of the fabric of the personal life of each of them.

Baker J noted that the same argument was had in oral submissions regarding the decision of Barrett J in Shishu v Minister for Justice and Equality [2019] IEHC 566, where he set out a number of informal translations of the German, Greek, and Spanish text of article 3(2)(1) of the Citizens' Directive. For example, Barrett I noted that the Spanish phrase vive con el, which Barrett J translated informally into English as 'lives with the Union citizen', seemed to connote no more than living under the same roof. Barrett J considered that, in principle at least, the German, Spanish, and Greek versions posited a test of living under the same roof or cohabitating, and that no element of identifying the 'head of the household' was required. However, Baker J held that the Court of Appeal was unable to resolve this issue in the light of the bare informal translation carried out by Barrett $J$ and in the absence of further evidence such as expert evidence as to possible varying translations of the Directive or how the term has been interpreted in other Member States. For all these reasons, the Court of Appeal dismissed the appeal. The decision in Subhan and Ali is under appeal to the Supreme Court. 


\section{CHAPTER 4}

\section{International protection}

\subsection{INTERNATIONAL PROTECTION STATISTICS}

\subsubsection{Protection applicants}

During 2019, a total of 4,781 applications for international protection status were submitted to the International Protection Office (IPO). This was an increase of 30.2 per cent over the 3,673 applications for refugee status submitted to the IPO in 2018.

As Figure 4.1 shows, the main countries of origin for applicants in 2019 were Albania (20.4\%), Georgia (13.3\%), Zimbabwe (9.3\%), Nigeria (8.1\%) and South Africa (6.7\%).

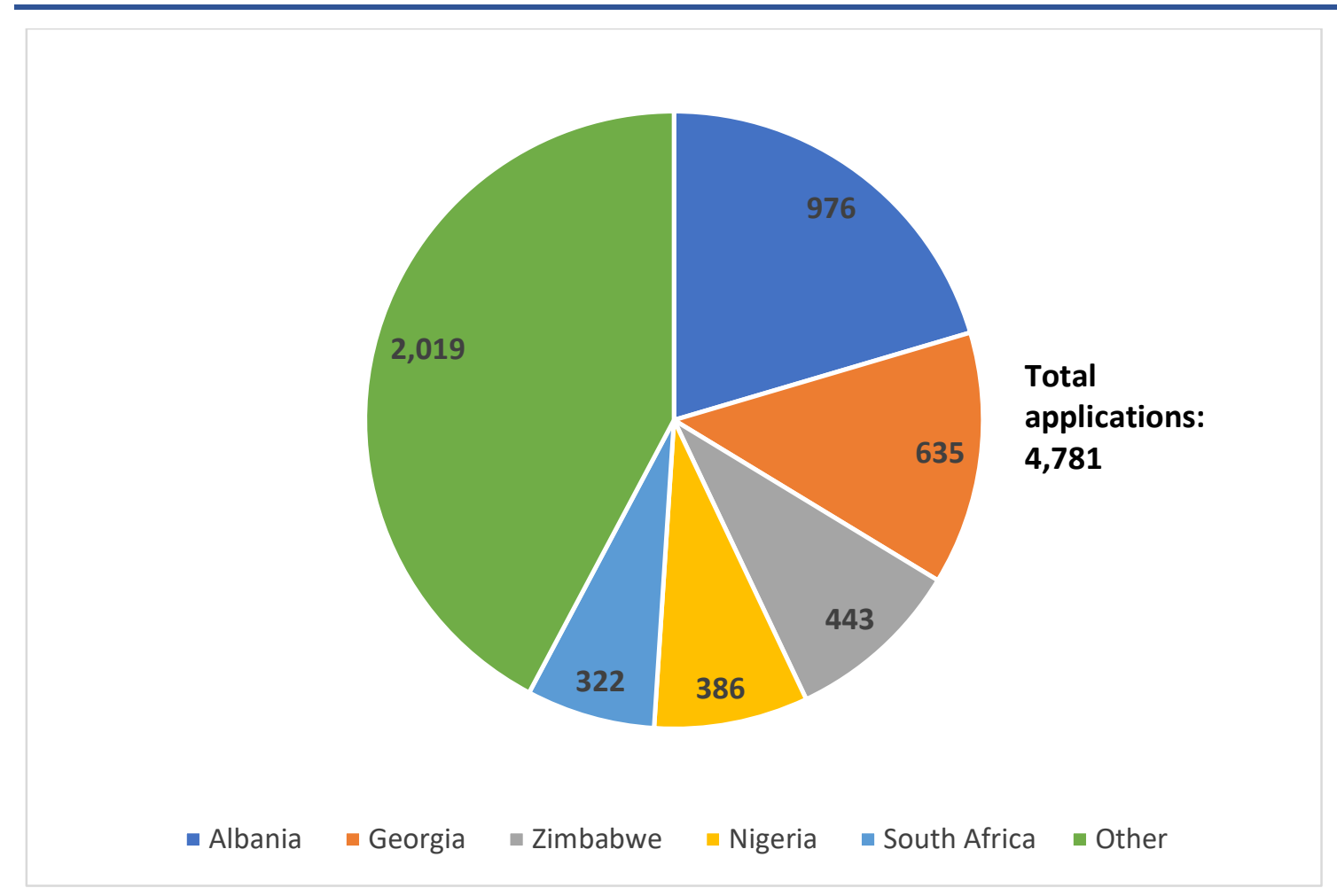

Source: International Protection Office Statistics, December 2019.

As in 2018, Albania was the top nationality for international protection applications, with 976 applications. This was a substantial increase of 112 per cent over the 2018 total of 459, which in turn was an increase of 62.7 per cent over the 2017 total of 282 applications. Also, as in 2018 , the second highest nationality was 
Georgia, with 635 applications, an increase of 41 per cent from the 2018 total of 450. Albania, Georgia and South Africa are designated safe countries of origin on the list via the International Protection Act 2015 (Safe Countries of Origin) Order 2018.

As in 2018 and previous years, Nigeria and Zimbabwe were among Ireland's top five nationalities for applicants.

Ireland's applications accounted for 0.64 per cent of the total 745,225 asylum applications to the EU-28 countries in 2019. ${ }^{148}$ See Table 4.1 for the percentage share of the top five countries of origin of applicants in Ireland in 2019, out of the total applications in the EU-28.

TABLE 4.1 SHARE OF TOTAL EU PROTECTION APPLICATIONS FOR TOP NATIONALITIES OF PROTECTION APPLICANTS IN IRELAND, 2019

\begin{tabular}{|l|l|l|l|}
\hline Country of origin of applicant & \multicolumn{1}{|c|}{$\begin{array}{c}\text { Ireland total } \\
\text { (rounded) } \text { (49 }^{\text {(ro }}\end{array}$} & EU-28 total & $\begin{array}{l}\text { Ireland \% share of EU- } \\
\mathbf{2 8} \text { total }\end{array}$ \\
\hline Albania & 975 & 24,705 & 3.94 \\
\hline Georgia & 635 & 22,380 & 2.84 \\
\hline Zimbabwe & 445 & 935 & 47.5 \\
\hline Nigeria & 385 & 26,950 & 1.42 \\
\hline South Africa & 320 & 580 & 55.17 \\
\hline Total applications & 4,780 & 745,225 & 0.64 \\
\hline
\end{tabular}

Source: Eurostat, 'Asylum and first-time asylum applicants by citizenship, age and sex, annual aggregated data (rounded)' [migr_asyapctza], data extracted on 28 October 2020.

The IPO processed a total of 4,927 cases to completion in 2019 - this includes firstinstance recommendations in respect of international protection, decisions in respect of permission to remain, legacy subsidiary protection recommendations, Dublin decisions to transfer and decisions in respect of reviews of permission to remain. ${ }^{150}$

\subsubsection{Dublin III Regulation}

Under the Dublin III Regulation, a total of 1,763 requests were sent by Ireland under the outgoing procedure ${ }^{151}$ (of which 1,077 were 'take charge' requests and

\footnotetext{
148 Eurostat, 'Asylum and first-time asylum applicants by citizenship, age and sex, annual aggregated data (rounded)' [migr_asyapctza], data extracted on 27 October 2020. Available at: https://ec.europa.eu/eurostat

149 For comparability purposes, rounded Eurostat totals are used in Table 4.1. Actual numbers of applications to Ireland are shown in Figure 4.1

150 Correspondence with International Protection Office, April and November 2020.

151 Correspondence with International Protection Office, November 2020.
} 
686 were 'take back' requests) and there were a total of 30 outgoing transfers in 2019. ${ }^{152}$ There were 206 requests under the incoming procedure (20 'take charge' and 186 'take back') and 23 persons were transferred to Ireland. ${ }^{153}$

\subsubsection{Decisions on protection applications}

Statistics reported to Eurostat by Ireland on asylum decisions are of first-instance decisions made by the Minister for Justice pursuant to recommendations by the IPO, or final decisions made by the Minister following appeal decisions of the International Protection Appeals Tribunal (IPAT). ${ }^{154}$

According to Eurostat (rounded) figures, Ireland made a total of 1,870 first-instance decisions in 2019. Of the 975 positive decisions in 2019, there were 585 grants of refugee status, 120 grants of subsidiary protection status and 265 grants of humanitarian status. Some 895 negative decisions were reported.

According to Eurostat (rounded) data, there were 55 grants of refugee status at first instance to applicants with Syria as country of citizenship in 2019, as compared to 425 in 2018. Other countries of citizenship for grants of refugee status at first instance included: Zimbabwe (55); Libya (45); Brazil (40); Sudan (40); Pakistan (40); Afghanistan (35); Democratic Republic of Congo (35); Somalia (25); and Eritrea (20). ${ }^{155}$

As reported for 2018, the Department of Justice and Equality has clarified the distinction between first-instance recommendations made by the IPO and firstinstance decisions reported to Eurostat.

Applications for international protection are first considered by the International Protection Office (IPO), which makes a recommendation to the Minister as to whether the application should be granted. Where this recommendation is positive, a formal decision is then made by the Ministerial Decisions Unit (MDU) following a process of due diligence checks. Where the IPO recommendation is negative, the applicant can appeal to the International Protection Appeals Tribunal.

The Ministerial Decisions Unit will only make negative decisions if an applicant chooses not to appeal the IPO recommendations, or after an

Correspondence with Repatriation Division, Department of Justice, October 2020.

Correspondence with International Protection Office, November 2020.

Section 47 of the International Protection Act 2015 provides for declarations of refugee status or subsidiary protection status by the Minister for Justice and Equality pursuant to recommendations to grant either status at first instance under section 39 of the Act or pursuant to successful appeals of negative recommendations under section 46 of the Act.

155 Eurostat, 'First instance decisions on applications by citizenship, age and sex - annual aggregated data (rounded)' [migr_asydcfsta], Data extracted 29 October 2020. Available at: https://ec.europa.eu/eurostat. 
applicant has exhausted the appeals mechanism, and where the original negative recommendation has been upheld.

Hence the statistics which Ireland is required to provide to Eurostat, which relate only to decisions issued on behalf of the Minister, will never be directly comparable to recommendations issued by the International Protection Office. ${ }^{156}$

Table 4.2 shows the total positive decisions at first instance and for final decisions for Ireland in 2019, according to Eurostat data.

TABLE 4.2 POSITIVE PROTECTION DECISIONS AT FIRST INSTANCE AND FINAL DECISIONS (ROUNDED), IRELAND 2019

\begin{tabular}{|l|l|l|l|l|}
\hline & Geneva Convention & \multicolumn{1}{|c|}{$\begin{array}{c}\text { Subsidiary } \\
\text { protection }\end{array}$} & $\begin{array}{l}\text { Humanitarian } \\
\text { status }\end{array}$ & Total \\
\hline $\begin{array}{l}\text { Positive first-instance } \\
\text { decisions }\end{array}$ & 585 & 120 & 265 & 975 \\
\hline $\begin{array}{l}\text { Positive final decisions } \\
\text { S60 }\end{array}$ & 45 & 170 & 575
\end{tabular}

Source: Eurostat, 'First instance decisions on applications by citizenship, age and sex - annual aggregated data (rounded)' [migr_asydcfsta], data extracted 29 October 2020; 'Final decisions in appeal or review on applications by citizenship, age and sex - annual data (rounded)' [migr_asydcfina], data extracted 2 November 2020.

\subsubsection{Permission to remain}

The Minister for Justice and Equality granted permission to remain under section 49 of the International Protection Act 2015 to a total of 266 persons in 2019. In addition, a further 169 persons were granted permission to remain status at review stage. ${ }^{157}$

\subsubsection{Appeals}

Throughout 2019, a total of 2,043 appeals in relation to international protection and the Dublin III Regulation were received by the IPAT. This total includes substantive international protection appeals, legacy international protection appeals, inadmissibility and subsequent appeals and appeals under the Dublin III

156 Correspondence with Ministerial Decisions Unit, Department of Justice and Equality, October 2019. Sheridan, A. (November 2019) Annual Report on Migration and Asylum 2018: Ireland, pp. 62-63. Available at: WwW.emn.ie and www.esri.ie.

157 Department of Justice and Equality (9 June 2020), Response to Parliamentary Question 10244/20. Available at: www.justice.ie. 
Regulation. ${ }^{158}$ This contrasts with 2,127 appeals received in $2018 .{ }^{159}$ While the overall numbers remained stable, the IPAT's Annual Report 2019 notes that:

It is likely that the caseload of the Tribunal will continue to rise over the coming period and it is imperative that the Tribunal is equipped, both with regard to staffing numbers and the availability of Tribunal members who are trained and experienced in the efficient delivery of high quality determinations of international protection appeals. This is particularly pertinent in light of the three-year term of appointment of the majority of Tribunal members pursuant to section 62 (7) (d) of the International Protection Act 2015 ending during the course of 2020. ${ }^{160}$

In addition, the IPAT received appeals under the provisions of Regulation 21 of the Reception Conditions Regulations 2018, which give effect to the EU Reception Conditions Directive (2013/33/EU) in Irish law. Applicants may appeal decisions refusing to grant, to reduce or, in exceptional circumstances, to withdraw material reception conditions as well as decisions to refuse a labour market access permission to the IPAT. A total of 21 appeals were received under the Regulations in 2019, as compared with 24 appeals received in 2018. This brought the overall total appeals received by the IPAT in 2019 to 2,064. ${ }^{161}$

As shown in Figure 4.2, the top five countries of origin for substantive international protection appeals received by the IPAT during 2019 were Pakistan, Zimbabwe, Albania, Nigeria and Bangladesh. Bangladesh was not among the top five countries of origin of appellants in 2018. 
FIGURE 4.2 TOP FIVE NATIONALITIES OF APPELLANTS TO IPAT, 2019

Total Substantive international protection appeals: 1,503

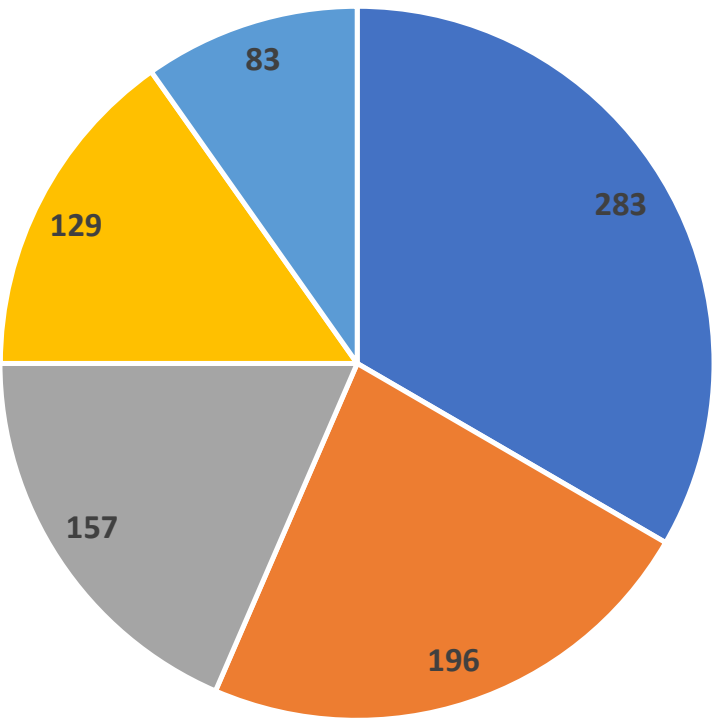

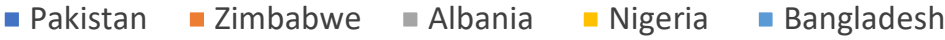

Source: International Protection Appeals Tribunal Annual Report 2019.

The IPAT scheduled hearings in 2,633 cases in 2019, an increase of 53.6 per cent on the 1,714 hearings scheduled in $2018 .{ }^{162}$

Decisions were issued in 1,944 cases, an increase of 78 per cent over the total of 1,092 decisions issued in 2018. In total, 2,180 appeals were completed, with 1,558 appeals on hand at the end of 2019. ${ }^{163}$

The breakdown of decisions between the different types of appeal is set out in Table 4.3.

Ibid., p. 32

Ibid., pp. $44-48$. 
Refugee status decisions under the transitional provisions of the International Protection Act 2015 (section $70(7)$ )

Subsidiary protection decisions under the transitional provisions of the International Protection Act 2015 (sections $70(5)$ and $70(8)$ )

Source: International Protection Appeals Tribunal Annual Report 2019.

The IPAT affirmed the first-instance recommendation in 1,133 international protection single procedure appeals in 2019, i.e. 71 per cent of a total of 1,585 decisions. ${ }^{164}$ The total set-asides - where the appellant's appeal was successful were 411 for asylum cases and 41 for subsidiary protection. ${ }^{165}$

Under the Dublin III Regulation, which establishes the criteria and mechanisms for determining the Member State responsible for examining an application for international protection, the IPAT affirmed the original recommendation in 132 out of a total of 152 decisions, an affirmation rate of 87 per cent. ${ }^{166}$

\subsection{ADMINISTRATIVE DEVELOPMENTS}

\subsubsection{Processing times for international protection applications}

Median processing times for first-instance international protection applications had not been available during 2017 and 2018 after the introduction of the new single procedure under the International Protection Act 2015, due to the transition caseloads, and waiting times for substantive interview have been reported in previous reports of this series. ${ }^{167}$ This data are now available and the median

164 These figures do not include withdrawals or abandoned cases. p. 52.

166 Ibid., p. 54.

167 In January 2018, it was estimated that it would take 19 months for a non-prioritised application made in January 2018 to reach interview. Waiting times for substantive interview for non-prioritised applications made in December 2018 were significantly reduced to approximately 8-10 months. Sheridan, A. (November 2019) Annual Report on Migration and Asylum 2018: Ireland, p. 71. Available at: www.emn.ie and www.esri.ie. 
processing time in 2019 for an application made under the International Protection Act 2015 (full single procedure cases) to first instance recommendation was 15.6 months. ${ }^{168}$ According to the Minister for Justice and Equality in June 2019, it was the Department's aim 'to reduce waiting times for recommendations at the first instance stage with the IPO to 9 months by the end of 2019 subject to the levels of new applications, etc.'. ${ }^{169}$

The prioritisation procedure relating to the scheduling of interviews for certain categories of international protection applications, which had been introduced in February 2017, continued during 2019. The prioritised categories include applications that are well founded, from certain vulnerable groups (unaccompanied minors; applicants aged over 70 not part of a family group), and applicants from certain countries of origin or habitual residence such as Syria. In previous years, waiting times for interviews for prioritised applications were considerably shorter. ${ }^{170}$ In Quarter 42019 the median processing time for a prioritised application was 9.4 months. ${ }^{171}$

\section{Processing times for appeals}

The average time for the IPAT to process substantive international protection appeals, including 'transition' cases, in 2019 was approximately 170 days. However, for appeals that were both accepted and completed within the year 2019, the average processing time was 100 days. ${ }^{172}$ Processing times during the year were impacted by a high number of postponements $\left(930^{173}\right)$, a significant number of which were due to a pending High Court challenge against the validity of the underlying recommendation from the IPO under section 39(3) of the International Protection Act 2015 and an injunction granted by the Court of Appeal in the matter of RS v The Chief International Protection Officer and Ors [2018] IECA 322 in October 2018.

\subsubsection{New locations for protection interviews}

Arising from a commitment given in late 2018, the IPO began to work to hold interviews outside Dublin to avoid applicants having to make long journeys to Dublin, including a possible overnight stay. A series of pilots were held in Tipperary town during the first half of 2019, but the location proved difficult to access by public transport. Interviews commenced in Cork in July 2019. The interviews in

168 Correspondence with International Protection Office, March 2020.

169 Department of Justice and Equality (27 June 2019) Response to Parliamentary Question 27296/19. Available at: www.justice.ie.

170 In December 2018, the waiting time to substantive interview for a prioritised application was approximately four months.

171 Correspondence with International Protection Office, November 2020.

172 International Protection Appeals Tribunal (March 2020) International Protection Appeals Tribunal Annual Report 2019, p. 50. Available at: www.protectionappeals.ie.

173 Ibid., p. 42. 
Cork were held via video conference from November 2019. The IPO then began the next phase of the project and engaged with the Courts service to conduct interviews from video suites in courthouses. This commenced with the first interviews from Sligo courthouse held in January 2020. ${ }^{174}$

\subsection{LEGAL DEVELOPMENTS}

\subsubsection{Judicial review in relation to Tribunal decisions}

The IPAT notes in its Annual Report 2019 that it follows developments closely in the Superior Courts in relation to challenges to its decisions and incorporates the jurisprudence in the guidance and training provided to IPAT members. This includes summarising judgments in information notes provided to members, taking account of developments in the law in the Chairperson's Guidelines issued under section 63(2) of the International Protection Act 2015, and through revision and updating of decision-making templates. ${ }^{175}$

\section{Judicial Review Knowledge Management Project}

During 2019, the IPAT undertook a project to consolidate all information relating to litigation against the Tribunal since its inception on 31 December 2016. The aim of the project is to enable the IPAT to set out clear statistics in relation to litigation against its decisions. In its Annual Report 2019, the IPAT notes that, overall, the number of single procedure appeal decisions that have been the subject of judicial review is relatively low, for example around 5 per cent in 2019, which the IPAT considers reflects the overall high standard of decision-making. The kinds of issues that arise in litigation, including in relation to fair procedures in a number of contexts and credibility, are set out in the IPAT's Annual Report 2019. ${ }^{176}$

\subsubsection{Guidelines of Chairperson of the IPAT}

Section 63(2) of the International Protection Act 2015 provides that the Chairperson of the IPAT may issue the members with guidelines on the practical application and operation of the Act, and on legal developments in relation to international protection. 
Chairperson's Guidelines on Taking Evidence from appellants and other witnesses were published in January 2019. ${ }^{177}$

\subsubsection{Preliminary reference to Court of Justice of the European Union (CJEU)}

Of the 21 appeals relating to the European Communities (Reception Conditions) Regulations 2018 that were received by the IPAT in 2019, 14 decisions were stayed pending the CJEU ruling in the preliminary reference made by the IPAT on 16 May 2019 - Case C-385/19. The appeals relate to the entitlement to apply for access to the labour market under the Reception Conditions Regulations 2018 for persons who are subject to transfer decisions pursuant to the European Union (Dublin System) Regulations 2018. Under the Reception Conditions Regulations 2018, persons subject to a Dublin transfer are not 'applicants' in the meaning of the Regulations and are not entitled to access the labour market. In 2018, when appeals came before the IPAT, it applied Irish law and affirmed the decisions of the Review Officer. These decisions were challenged by judicial review.

However, in December 2018, the CJEU decision in the case Minister for Justice \& Equality \& Others v Workplace Relations Commission \& Others (C-378/17) held that quasi-judicial bodies, in circumstances where national and EU law contradicts, are obliged to disapply national law in favour of EU law. As a result, the IPAT disapplied national law under the Reception Conditions Regulations 2018 in relation to 'applicant' and set aside two Review Officer decisions in December 2018 and May 2019.

The IPAT's preliminary reference in relation to two appeals received in April and May 2019 (Case C-385/19) has been joined by the CJEU with the earlier preliminary reference made by the High Court in KS (Pakistan) \& MHK (Bangladesh) $v$ IPAT [2019] IEHC 276 (Case C-322/19) in relation to two of the original decisions made by the IPAT. ${ }^{178}$ The two preliminary references ask different questions, in relation to Article 15 of the Reception Conditions Directive (2013/33/EU) on the right of access to the labour market. However, both sets of questions centre on the interpretation of 'applicant' under Article 15 of Directive 2013/33/EU and the circumstances in which delay in examining an application for international

177 http://www.protectionappeals.ie/website/rat/ratweb.nsf/page/MXKY-B9KK4514334220en/\$File/Guideline\%2020191\%20on\%20Taking\%20Evidence\%20from\%20Appellants\%20and\%200ther\%20Witnesses.pdf.

178 International Protection Appeals Tribunal (March 2020) Annual Report 2019, pp. 56-57. Available at: www.protectionappeals.ie. 
protection can be attributable to the applicant for the purposes of Article 15 of the Directive. ${ }^{179}$

\subsubsection{Caselaw}

Appendix 4 of the IPAT Annual Report for 2019 also includes summaries of the judgments of the Superior Courts in 2019 regarding Tribunal decisions. ${ }^{180}$

\subsection{IRISH REFUGEE PROTECTION PROGRAMME}

As reported for previous years, in September 2015, the Irish Government established the Irish Refugee Protection Programme (IRPP). Under the Programme, Ireland agreed to accept up to 4,000 asylum seekers and refugees overall into Ireland under relocation and resettlement programmes at the earliest time possible.

\subsubsection{Relocation}

Ireland opted into the two EU decisions on Relocation - Council Decision (EU) 2015/1523 of 14 September 2015 and Council Decision (EU) 2015/1601 of 22 September 2015. The relocation strand of the IRPP, in which Ireland relocated a total of 1,022 persons from Greece, was concluded in March 2018. ${ }^{181}$

\section{Distribution of migrants rescued in the Mediterranean}

As reported in 2018, Ireland has responded positively to requests to accept migrants rescued in the Mediterranean and disembarked in Italy and Malta. On foot of requests from the European Commission, Ireland agreed to accept up to a maximum of 163 persons under the entirety of the programme. Some 72 persons had been relocated under the programme to year end 2019. ${ }^{182} \mathrm{~A}$ total of 14 protection applications were made from persons relocated to Ireland under the search and rescue operations in the Mediterranean in 2019. ${ }^{183}$

\subsubsection{Resettlement}

A total of 783 persons were resettled to Ireland, with the assistance of the International Organization for Migration (IOM), under the United Nations High Commissioner for Refugees (UNHCR) resettlement programme in $2019 .{ }^{184}$ As at 31 December 2019, a total of 1,913 persons had been resettled over the duration of

179 See Opinion of Advocate General De La Tour in Joined Cases C-322/19 and C-385/19, 3 September 2020. Available at: www.curia.europa.eu.

180 International Protection Appeals Tribunal (March 2020) Annual Report 2019. Available at: www.protectionappeals.ie.

181 Sheridan, A. (November 2019) Annual Report on Migration and Asylum 2018: Ireland, pp. 86-87. Available at: www.emn.ie and www.esri.ie.

182 Correspondence with Department of Children, Equality, Disability, Integration and Youth, IRPP, November 2020.

183 Correspondence with International Protection Office, November 2020.

184 Correspondence with Irish Refugee Protection Programme, Department of Justice and Equality, February 2020. 
the IRPP. A balance of 72 persons remained to be resettled from Lebanon in early 2020. In September 2019, the Irish Refugee and Migrant Coalition (IRMC), a coalition of non-governmental organisations (NGOs), called for an increase in the commitment to refugee resettlement. ${ }^{185}$

\section{New refugee protection programme}

The Minister of State at the Department of Justice and Equality announced plans to resettle up to 2,900 refugees through a combination of resettlement and community sponsorship between 2020 and 2023 at the Global Refugee Forum held by UNHCR in Geneva on 18 December 2019. It was announced that a new phase of the IRPP would see 650 resettlements in 2020, 700 in 2021, 750 in 2022 and 800 in 2023. For the first two years, the arrivals will mostly comprise Syrian refugees who are resident in Jordan and Lebanon. There also will be a group of 150 Eritrean refugees, who are resident in Ethiopia. Between early 2020 and June 2021, funding of up to $€ 9$ million will be provided by the European Commission to support the resettlement of 900 people. ${ }^{186}$

UNHCR Ireland welcomed Ireland's pledge for the period 2020 to 2023, remarking that: 'The decision to increase resettlement by 20 per cent over the next four years is a very significant contribution, one that is urgently needed given the record number of people fleeing from war, conflict and persecution. ${ }^{187}$

\subsubsection{Community sponsorship}

Community Sponsorship Ireland commenced on a pilot basis in December 2018, when a Syrian family was welcomed to Dunshaughlin, Co. Meath with the support of Nasc and local community organisers. The pilot was launched in March 2019. ${ }^{188}$ Five families (17 persons) were resettled by host community groups in Cork, Waterford and Meath during the pilot phase. ${ }^{189}$ Following the pilot phase, Community Sponsorship Ireland was launched as a national programme on 11 November 2019. ${ }^{190}$

Community sponsorship is an alternative resettlement stream to the traditional state-centred model. The initial pilot model sought to enable interested groups

\footnotetext{
185 Irish Refugee and Migrant Coalition (13 September 2019) 'Irish Refugee and Migrant Coalition call on Irish Government to increase commitment to refugee resettlement', Press Release. Available at: www.nasc.org.

186 Department of Justice and Equality (17 December 2019) 'Ireland commits to a new Refugee Protection Programme', Press Release. Available at: www.justice.ie.

187 United Nations High Commissioner for Refugees (17 December 2019) 'UNHCR welcomes Ireland's decision to welcome 2,900 refugees over the next 4 years', Press Release. Available at: www.unhcr.org.

188 Department of Justice and Equality (6 March 2019) 'Minister Stanton calls on communities to sponsor a refugee family as he launches pilot Community Sponsorship Ireland initiative', Press Release. Available at: www.justice.ie

189 Department of Justice and Equality (30 December 2019) 'Minister Flanagan welcomes Syrian refugee families at Mosney', Press Release. Available at: www.justice.ie.

190 Department of Justice and Equality (15 November 2019) 'Minister Stanton officially launches Refugee Community Sponsorship Ireland', Press Release. Available at: www.justice.ie.
} 
within a community to come together to support arriving refugees as a Community Sponsorship Group (CSG). ${ }^{191}$ The local group provides supports around access to housing and to different state services. Refugees arrive in Ireland following selection by UNHCR and a vetting process overseen by the IRPP. 192

The Irish model was developed in co-operation with the Government of Ireland, Immigration, Refugees and Citizenship Canada (IRCC) and civil society organisations such as UNHCR, the Irish Red Cross, Nasc, the Irish Refugee Council (IRC) and Amnesty International Ireland. The launch of the pilot programme was welcomed by the IRC, Nasc and the Irish Red Cross, all of which are available as regional support organisations for communities who may wish to get involved in sponsoring a refugee family. ${ }^{193}$ Local development companies, such as Waterford Leadership Partnership (WLP), are also designated as regional support organisations. ${ }^{194}$ UNHCR welcomed the launch of the official national programme in November. ${ }^{195}$

Ireland received the first 'International' award from the Global Refugee Sponsorship Initiative (GRSI) in October 2019, in recognition of the pilot community sponsorship initiative. The GRSI is a joint initiative led by the Government of Canada, the United Nations High Commissioner for Refugees (UNHCR), the Open Society Foundations, the Giustra Foundation and the University of Ottawa, with the aim to:

- increase and improve global refugee resettlement by engaging private citizens, communities, and businesses in resettlement efforts;

- strengthen local host communities that come together to welcome newcomers;

- improve the narrative about refugees and other newcomers. ${ }^{196}$

Following the launch of the programme in November 2019, three additional host communities received refugee families - Kinsale, Rathgar and Clane/Rathcoffey -

191 Department of Justice and Equality (6 March 2019) 'Minister Stanton calls on communities to sponsor a refugee family as he launches pilot Community Sponsorship Ireland initiative', Press Release. Available at: www.justice.ie.

192 Department of Justice and Equality (17 December 2019) 'Ireland commits to a new Refugee Protection Programme', Press Release. Available at: www.justice.ie.

193 Irish Refugee Council (6 March 2019) 'Regional support organisations welcome official launch by Minister Stanton of Community Sponsorship', Press Release. Available at: www.irishrefugeecouncil.ie.

194 See https://www.wlp.ie/community-sponsorship/.

195 United Nations High Commissioner for Refugees (15 November 2019) 'Ireland strengthens response to refugee protection with the formal launch of Community Sponsorship programme', Press Release. Available at: www.unhcr.org. Department of Justice and Equality (11 October 2019) 'Minister Stanton welcomes the announcement of the GRSI 'International Award' to Ireland for the Community Sponsorship Initiative (CSI)', Press Release. Available at: www.justice.ie. 
and a total of 30 individuals (eight families) had been resettled under Community Sponsorship Ireland by December 2019. ${ }^{197}$

\subsubsection{Emergency Reception and Orientation Centres}

Among the measures agreed under the IRPP was the establishment of Emergency Reception and Orientation Centres (EROCs) which are used to provide initial accommodation for asylum seekers relocated from Greece while their applications for international protection status are processed. EROCs are also used to provide temporary initial housing for refugees arriving under the resettlement strand of the IRPP. The facilities and services provided include onsite education, health and social protection services, orientation classes and IRPP clinics. ${ }^{198}$ Residents of EROCs can make complaints to the Office of the Ombudsman and to the Ombudsman for Children. ${ }^{199}$

The Office of the Ombudsman received three complaints from residents of EROCs during 2019. These related to food and interpretation services, and the Ombudsman noted that the problem in these cases was gaps in communication between residents and centre management. ${ }^{200}$ This was a decrease from the 18 complaints received in 2018. As reported for 2018, 17 of the 2018 complaints had related to access to housing. ${ }^{201}$ The Ombudsman noted in his 2019 Update on Direct Provision that:

During 2018 the IRPP changed its process for allocating housing which was designed to reduce the length of time people had previously been waiting for housing. Progress on this was borne out in the team's 2019 visits to the EROCs where most residents are now housed within six months. ${ }^{202}$

\subsubsection{Irish Humanitarian Assistance Programme}

The second call for applications under the Irish Humanitarian Assistance Programme (IHAP 2018/2019) closed on 8 February 2019.

197 Correspondence with Irish Refugee Protection Programme (February 2020); United Nations High Commissioner for Refugees (17 December 2019) 'UNHCR welcomes Ireland's decision to welcome 2,900 refugees over the next 4 years', Press Release. Available at: www.unhcr.org.

198 Sheridan, A. (November 2019) Annual Report on Migration and Asylum 2018: Ireland, pp. 89-90. Available at: www.emn.ie and www.esri.ie.

199 Department of Justice and Equality (28 May 2019) Response to Parliamentary Question 22593/19. Available at: www.justice.ie.

200 Office of the Ombudsman (April 2020) The Ombudsman \& Direct Provision: Update for 2019. A commentary by the Ombudsman, p. 23. Available at: www.ombudsman.ie.

201 Sheridan, A. (November 2019) Annual Report on Migration and Asylum 2018: Ireland, p. 90. Available at: www.emn.ie and www.esri.ie.

202 Office of the Ombudsman (April 2020) The Ombudsman \& Direct Provision: Update for 2019. A commentary by the Ombudsman, p. 23. Available at: www.ombudsman.ie. 
The IHAP provides for up to $740^{203}$ eligible family members ('beneficiaries') of Irish citizens, persons with Convention refugee or subsidiary protection status, and persons with programme refugee status ('the sponsor') from eligible countries of nationality to be admitted to Ireland over two years. ${ }^{204}$ In deciding the eligible countries of nationality for consideration under the IHAP, the Department of Justice and Equality chose the top 10 major source countries of refugees set out in UNHCR's Annual Global Trends Report. During the first and second calls for the IHAP programme these countries were: Syria, Afghanistan, South Sudan, Somalia, Sudan, the Democratic Republic of Congo, Central African Republic, Myanmar, Eritrea and Burundi. ${ }^{205}$

Some 192 persons had arrived under the IHAP programme by year end 2019. Beneficiaries make their own travel arrangements to Ireland. The Department of Children, Equality, Disability, Integration and Youth (DCEDIY) has clarified that:

This means that numbers of arrivals under the IHAP programme are recorded only when the beneficiaries themselves notify the Department of their arrival in the State. This is an ongoing process that can result in the numbers of arrivals in any given year changing retrospectively over time. ${ }^{206}$

\subsection{FAMILY REUNIFICATION}

\subsubsection{Statistics}

During 2019, some 307 family reunification applications were received under the International Protection Act 2015 in respect of 737 subjects. Some 254 subjects were approved; however, some of these may relate to applications made in previous years. The top five nationalities of subjects accepted were: Syrian Arab Republic, Zimbabwe, Somalia, Democratic Republic of Congo and Afghanistan. ${ }^{207}$

\subsubsection{International Protection Act (Family Reunification) (Amendment) Bill 2017}

As reported in previous years, the International Protection Act (Family Reunification) (Amendment) Bill 2017 was initiated as a private members' bill (PMB) in Seanad Éireann in July 2017. The Bill proposed changes to the

\footnotetext{
203 The original commitment was for up to 530 family members. Sheridan, A. (November 2019) Annual Report on Migration and Asylum 2018: Ireland, p. 91.

204 Department of Justice and Equality (30 December 2019) 'Minister Flanagan welcomes Syrian refugee families at Mosney', Press Release. Available at: www.justice.ie.

205 Sheridan, A. (November 2018) Annual Report on Migration and Asylum 2018: Ireland, p. 91. Available at: www.emn.ie and www.esri.ie.

206 Correspondence with DCEDIY, November 2020.

207 Correspondence with Immigration Service Delivery, Department of Justice and Equality, February 2020.
} 
International Protection Act 2015 to reinstate the discretionary power of the Minister for Justice and Equality, which had been provided for under section 18(4) of the Refugee Act 1996, to allow dependent family members, other than immediate family members, to enter the State. It also proposed to remove the 12month time limit on family reunification applicants. The Bill passed Committee Stage at Seanad Éireann in November 2017 and was initiated in Dáil Éireann in December 2018. Following the second stage debate, it was referred to the Select Committee on Justice and Equality on 13 December 2018. The proposers of the Bill emphasised its purpose to provide a statutory basis for the Minister's decisionmaking in relation to family members beyond the immediate family, and the Minister for Justice and Equality stressed the resource implications of the legislation, to the extent that the Government would decline a money message ${ }^{208}$ if one was required for passage of the Bill, and pointing to the possibility for flexibility in humanitarian cases under the INIS [Irish Naturalisation and Immigration Service] Policy Document on non-EEA family reunification. ${ }^{209}$

Detailed scrutiny of the Bill was undertaken by the Joint Committee on Justice and Equality prior to formal consideration at Committee Stage, and a hearing was held on 6 February 2019 with witnesses invited from the Irish Refugee Council and Nasc. In July 2019, the Joint Committee published its scrutiny report ${ }^{210}$ and recommended that a money message should be granted and that the Bill should proceed to formal committee stage..$^{211}$

The Joint Committee considered the views of the witnesses in arriving at its recommendation. The observations of the Minister for Justice and Equality were also invited to the draft report and are included as an appendix. The witnesses argued that the current definition of family in the International Protection Act 2015 is too restrictive, 'ignoring the realities of modern familial relationships'. ${ }^{212}$ It was further argued that the provisions in the proposed Bill did not give rise to an automatic entitlement to family reunification and that the existing provisions for the Minister to refuse an application were retained. The IRC submitted that: 'the Minister will continue to have considerable power to control the process and to balance the applicant's rights and the State's power to regulate immigration as per the case law of the Supreme Court. ${ }^{213}$ In relation to the resource implications of the Bill, the proposer and witnesses argued that the provisions of the Bill were modest, that it did not appropriate public funds and did not require the set up of a

\footnotetext{
208 Money message: a recommendation from the Government, signed by the Taoiseach, supporting the expenditure of public moneys proposed by a PMB. Glossary of parliamentary terms. Available at: www.oireachtas.ie Sheridan, A. (November 2019) Annual Report on Migration and Asylum 2018: Ireland, pp. 92-94. Available at: www.emn.ie and www.esri.ie

210 Joint Committee on Justice and Equality (July 2019) Report on Scrutiny of the International Protection (Family Reunification) (Amendment) Bill 2017 [PMB] July 2019. Available at: www.oireachtas.ie

211 Ibid., p. 17.

212 Ibid., p. 11

213 Ibid., p. 12.
} 
new body. ${ }^{214}$ In its Conclusions, the Joint Committee welcomed the Bill and supported it 'as a relatively modest proposal to rectify undue restrictions introduced in the International Protection Act 2015.'215 Accordingly, it recommended that the Bill be sent forward for formal Committee Stage.

This Bill lapsed with the dissolution of the Dáil and Seanad on 14 January $2020 .{ }^{216}$

\subsection{RECEPTION}

\subsubsection{Right to work for international protection applicants}

As reported for 2018, the European Communities (Reception Conditions) Regulations 2018 provided for labour market access for protection applicants from 30 June 2018. Under the Regulations, protection applicants have access to the labour market nine months from the date when their protection application was lodged, if they have not yet received a first instance recommendation from the IPO and if they have co-operated with the process. Access is by way of a labour market access permission issued by the Minister for Justice and Equality. Eligible applicants have access to self-employment as well as all sectors of employment, with the exception of the Civil and Public Service, An Garda Síochána and the Irish Defence Forces (which are only open to European Economic Area (EEA) and Irish nationals).

When an international protection applicant is issued with a labour market access permission under the European Communities (Reception Conditions) Regulations 2018 and takes up employment, the employer (or the applicant in cases of selfemployment) is obliged to inform the Department of Justice and Equality within 21 days on a standard declaration form. ${ }^{217,218}$

By December 2019, over 3,400 labour market access permissions had been issued, ${ }^{219} 2,651$ in 2019. ${ }^{220}$ Based on returned declaration forms, 1,693 applicants had commenced employment or self-employment as of 14 November 2019.221

Ibid., p. 14.

Ibid., p. 16.

See International Protection (Family Reunification) (Amendment) Bill 2017 (Bill 101 of 2017). Available at: www.oireachtas.ie/bills.

217 Department of Justice and Equality (14 November 2019) Response to Parliamentary Question 46943/19. Available at: www.justice.ie

218 Form LMA5 available at: www.inis.gov.ie.

219 Department of Justice and Equality (2 December 2019) Opening Statement of Ireland at the Committee on the Elimination of Racial Discrimination. Available at: www.justice.ie.

220 Office of the Ombudsman (April 2020) The Ombudsman and Direct Provision: Update for 2019, p. 13.

221 Department of Justice and Equality (14 November 2019) Response to Parliamentary Question 46943/19. Available at: www.justice.ie. 


\section{Driving licences}

One issue that arose in relation to the right to work is access to driving licences for protection applicants. This has become an issue due to the remote location of some accommodation centres with poor public transport, and some work would require the applicant to be able to drive. In order to be eligible for a driver learner permit, an applicant must be normally resident in the State. The Road Safety Authority (RSA) has taken the view that a protection applicant is not normally resident for the purpose of the Regulations. ${ }^{222,223}$ An adjudication of the Workplace Relations Commission (WRC) in November 2019 found that the complainant had suffered indirect discrimination, and ordered the respondent to process the application for a learner permit and to pay compensation of $€ 2,500 .{ }^{224}$ However, the RSA has maintained its position and a learner permit has not been issued. ${ }^{225}$ The judgment of the Circuit Court during 2020 in an appeal from a similar case will be addressed in the next report of this series.

\subsubsection{Reception conditions}

\section{Reception capacity}

Pressure on accommodation supply continued to be a challenge during 2019.

As of 11 November 2019, 39 accommodation centres were operating throughout the State, with an approximate capacity of 6,140 bed spaces, accommodating 6,058 persons. $^{226}$ In 2019, 3,847 new applicants were accommodated by the International Protection Accommodation Service (IPAS), which represented 80.7 per cent of 4,767 new protection applications to the IPO (not including applications under the IRPP). ${ }^{227}$ The Office of the Ombudsman commented that IPAS had added 735 bed spaces to its portfolio in 2019, but with the closure of one centre (Hatch Hall) this resulted in a net increase of 515 bed spaces. ${ }^{228}$

In December 2018, the Department of Justice and Equality commenced a regional procurement process across eight regions for three reasons:

222 Road Traffic (Licensing of Drivers) Regulations 2006.

223 Government of Ireland (September 2020) Report of the Advisory Group on the Provision of Support including Accommodation to Persons in the International Protection Process, pp. 77-78. Available at: www.gov.ie.

224 Workplace Relations Commission (20 November 2019) Adjudication Reference: ADJ-00017832. An asylum seeker va Government agency. Note the parties were anonymised for this case. Available at: https://www.workplacerelations.ie/en/cases/2019/november/adj-00017832\%20.html.

225 Government of Ireland (September 2020) Report of the Advisory Group on the Provision of Support including Accommodation to Persons in the International Protection Process, pp. 77-78. Available at: www.gov.ie. Department of Justice and Equality (22 November 2019) 'Statement on tenders for accommodation centres for international protection applicants', Press Release. Available at: www.justice.ie.

227 Government of Ireland (September 2020) Report of the Advisory Group on the Provision of Support including Accommodation to Persons in the International Protection Process, p. 18. Available at: www.gov.ie.

228 Office of the Ombudsman (April 2020) The Ombudsman and Direct Provision: Update for 2019, p. 12. Available at: www.ombudsman.ie. 
1. to identify an additional supply of premises to meet the Department's increased need for accommodation;

2. to implement a common higher standard across all new and existing accommodation centres including the provision of independent living (allowing residents to cook for themselves and providing designated living space for families);

3. to address the recommendation of the Comptroller and Auditor General that the Department's use of accommodation and ancillary services for asylum seekers should be in line with EU procurement requirements.

The Department stressed that all existing contractors in the system would need to come through the procurement process in order to continue to operate beyond the expiration of their existing contract. 229

There were continued difficulties during 2019 with the opening of new accommodation centres, due to opposition in local communities. ${ }^{230}$ Due to the commercially sensitive nature of the procurement process, the Department is unable to publicly comment until contractual arrangements are finalised. The Minister for Justice and Equality commented on this problem in Seanad Éireann:

I am keenly aware of the dissatisfaction expressed by communities who hear through a rumour mill that a centre might be opening in their area. And, if the contractual arrangements are not finalised, feel frustrated when the Department is unable to publicly comment. [...] The common concerns expressed related to service provision - education, health, transport and so on. I want to say clearly that where a centre is opening, it is the responsibility of the Government to ensure that provision is made for any additional services required. And it is clear that we need to communicate clearly and promptly with communities on these issues to provide them with the reassurances they need. I would point out that we do not spontaneously create hotel rooms or apartments or other accommodation in a location when we propose to open a centre - these accommodation facilities already exist and could be fully occupied by anyone at any time - it should not create an issue that the occupants happen to be international protection applicants. ${ }^{231}$

229 Department of Justice and Equality (22 November 2019) 'Statement on tenders for accommodation centres for international protection applicants', Press Release. Available at: www.justice.ie.

230 See for example Department of Justice and Equality (1 October 2019) 'Statement from the Department of Justice and Equality regarding Oughterard'. Available at: www.justice.ie.

231 Department of Justice and Equality (27 November 2019) Statement by Minister for Justice and Equality on Provision of Accommodation and Ancillary Services to applicants for International Protection, Seanad Éireann, 27 November 2019. Available at: www.justice.ie. 
Accommodation centres were opened in 2019 at Borrisokane, with own-door accommodation for up to 16 families; Ballinamore, with 25 own-door apartments for up to 25 families; and Ennis for up to 64 individuals. A public information website, https://accommodationcentres.ie, has been established, which provides general information on new accommodation centres, including capacity, impact on local services (health, education and social protection) and encouraging members of the community to join local 'Friends of the Centre' groups. ${ }^{232}$

As was the case during 2018 , another challenge in relation to capacity was the number of persons with status who stay on in accommodation centres while they attempt to source accommodation in the community. The Minister for Justice and Equality commented on 3 December 2019 that approximately 860 people with status or permission to remain continued to live in accommodation centres. ${ }^{233}$ According to the Office of the Ombudsman, some 972 people with status were still living in direct provision accommodation at the end of $2019 .{ }^{234}$ Some organisations had received support from the Department of Justice and Equality to assist persons with status or permission to remain to access mainstream housing, for example under the PATHS project (Providing Asylum seekers in Transition with Housing and Support) funded under the Asylum, Migration and Integration Fund Ireland (20172019). ${ }^{235}$ According to the Office of the Ombudsman, some 832 persons had transitioned out of direct provision by the end of 2019. ${ }^{236}$ The Minister of State at the Department of Justice and Equality noted that the Department

has a specific team who work in collaboration with DePaul Ireland, the Jesuit Refugee Service, the Peter McVerry Trust, officials in the Department of Housing, Planning and Local Government, and the City and County Managers Association to collectively support residents with status or permission to remain to access housing options. ${ }^{237}$

\section{Emergency accommodation}

In addition, as of 11 November 2019, due to the sharp rise in international protection applications, the Department of Justice and Equality was using 37 hotels and guesthouses to provide temporary short-term accommodation for approximately 1,500 people. The Department stressed that this was a temporary measure, to be continued only until such time as sufficient places were available

\section{See https://accommodationcentres.ie.}

Department of Justice and Equality (3 December 2019) Response to parliamentary question 50267/19. Available at: www.oireachtas.ie.

234 Office of the Ombudsman (April 2020) The Ombudsman and Direct Provision: Update for 2019, p. 13. Available at: www.ombudsman.ie.

235 Sheridan, A. (November 2019) Annual Report on Migration and Asylum 2018: Ireland, p. 79. Available at: www.emn.ie and www.esri.ie.

236 Office of the Ombudsman (April 2020) The Ombudsman and Direct Provision: Update for 2019, p. 13. Available at: www.ombudsman.ie.

237 Department of Justice and Equality (3 December 2019) Response to parliamentary question 50106/19. Available at: www.kildarestreet.com. 
within the system to accommodate all protection applicants who wish to avail of the offer of accommodation while their application is being processed. ${ }^{238}$

Commentators, including the Ombudsman and the Irish Refugee Council (IRC), expressed serious reservations about the use of emergency accommodation. While welcoming the Ombudsman's 2019 update relating to direct provision, the IRC commented:

In particular the report raises serious concerns about the use of emergency accommodation and the problems people experience while living in it: location, schooling, food, sharing of rooms and laundry facilities. As an organisation we have been working with people living in such accommodation for the last year and a half and have also seen many of these issues. ${ }^{239}$

Speaking at the Joint Committee on Justice and Equality, officials from the Department of Justice and Equality agreed that the use of emergency accommodation was 'sub-optimal':

The use of emergency accommodation is sub-optimal. It is worse than direct provision. For all naysaying about direct provision, it allows us to provide public services in a more co-ordinated way to a group of people in a group setting. These are people who tend to have high levels of needs because of some of the circumstances from which they have come. The use of emergency accommodation is not where we want to be and we need to move away from that. As the use of emergency accommodation has become a more regular feature of the system, we have moved to improve our governance arrangements around it. ${ }^{240}$

In the same hearing, Department officials also indicated that they were working towards formalising the most important standards for those in emergency accommodation including child protection, educational needs and health screening. ${ }^{241}$ The Department acknowledged that the direct referral of applicants to emergency accommodation during 2019 initially resulted in some applicants not receiving the initial medical screening at the Balseskin reception centre. However,

238 Department of Justice and Equality (22 November 2019) 'Statement on tenders for accommodation centres for international protection applicants', Press Release. Available at: www.justice.ie.

239 Irish Refugee Council (April 2020) 'Irish Refugee Council welcome report: The Ombudsman \& Direct Provision: Update for 2019', Press Release. Available at: www.irishrefugeecouncil.ie.

240 Joint Committee on Justice and Equality (December 2019) Report on direct provision and the international protection process, p. 27. Available at: www.oireachtas.ie.

241 Ibid. 
the introduction of the SafetyNet mobile screening service was designed to address this issue. ${ }^{242}$

\section{Office of the Ombudsman 2019 commentary on direct provision}

The Office of the Ombudsman published a commentary on direct provision - The Ombudsman and Direct Provision: Update for 2019 - A commentary by the Ombudsman in April 2020. The Ombudsman can accept complaints directly from residents of direct provision centres since 3 April 2017.

The Office of the Ombudsman received a total of 168 complaints from residents of accommodation centres in 2019. Of these complaints, five were upheld, 23 not upheld, assistance was provided in 64 cases and 56 were discontinued or withdrawn. Also, some were outside the remit of the Ombudsman or still in progress. ${ }^{243}$

In 2019, complaints were received in relation to issues that were specific to accommodation in emergency accommodation centres. For example, residents in emergency accommodation centres reported difficulties and delays in accessing Personal Public Service Numbers (PPSNs) and health services (general practitioner (GP) practices and delays in medical cards). Due to the numbers of applicants arriving, some 1,573 applicants were transferred directly to emergency centres between May 2019 and the end of January 2020. These groups could, therefore, not avail of the co-ordinated services and initial health screening provided in the Balseskin reception centre. ${ }^{244}$

One difficulty reported was delays in accessing PPSNs and a higher threshold of proof of identification being applied for this group. The PPSN is required to access Exceptional Needs Payments and the medical card. The Office of the Ombudsman engaged with the Department of Employment Affairs and Social Protection (DEASP), which resulted in a notice being issued to all local offices clarifying the proof of identification required and indicating that these applicants be dealt with urgently. ${ }^{245}$

Residents of emergency accommodation also complained about the time spent in emergency accommodation and that some residents appeared to be transferred more quickly to permanent centres. The Ombudsman acknowledged that this is often unavoidable as transfers can be prioritised for reasons such as family composition or need to access health services. The Ombudsman recommended

Ibid., p. 32.

Office of the Ombudsman (April 2020) The Ombudsman and Direct Provision: Update for 2019 - A commentary by the Ombudsman, p. 33. Available at: www.ombudsman.ie. 
that clearer communication could help address managing residents' expectations in this regard. ${ }^{246}$

The Ombudsman welcomed the fact that the IPAS engaged the Jesuit Refugee Service (JRS) in August 2019 to assist residents directly with raising issues of concern. As part of this service, the JRS is providing a cultural liaison service to approximately half of residents in emergency accommodation. ${ }^{247}$

In terms of reception conditions, residents in emergency accommodation made complaints about similar issues to residents in permanent centres, e.g. food or access to transport. One issue particular to emergency centres was lack of access to laundry facilities. The Ombudsman noted that from late 2019, IPAS had taken steps to ensure that all residents in emergency centres had access to laundry services either onsite or via an external collection service. ${ }^{248}$

In general, one of the most serious concerns expressed by the Ombudsman in the 2019 commentary related to the use of emergency accommodation. While the Ombudsman understood the difficulties faced by the Department of Justice and Equality to keep pace with the rise in international protection applications, he emphasised the unsuitable nature of emergency accommodation:

I fully understand the dilemma IPAS is in as it is simply impossible to predict accurately the demand for international protection. I also understand that provision of new medium to long-term accommodation unavoidably takes time to deliver. Furthermore, I acknowledge the great work done by IPAS staff in responding to the threats posed by Covid-19 by moving over 300 people out of emergency centres shared with other people to locations occupied exclusively by applicants for international protection. However, while I have sympathy for the position IPAS finds itself in, it is simply unacceptable that people who have sought refuge in this country can find themselves in accommodation that is entirely unsuitable for their needs for a prolonged length of time, up to sixteen months and counting in some cases. $^{249}$

The Ombudsman also welcomed that the IPAS is examining the feasibility of moving towards a capital investment-based approach. He said:

I fully welcome this change in approach. Accommodating people in Direct Provision centres has been a feature of our national administration for 
over twenty years but it is only much more recently that we have seen a strategic and joined-up approach to provision of the service. Moving towards a capital investment approach to provide appropriate accommodation is another example of this integrated strategy. This approach would also reduce the ongoing reliance on conversion of existing buildings which has presented, and continues to present, significant challenges to IPAS in delivering appropriate accommodation. ${ }^{250}$

In a statement responding to the Ombudsman's 2019 commentary, the Department of Justice and Equality acknowledged the good relationship between the Ombudsman's office and IPAS officials, enabling issues brought to the attention of the Department to be quickly resolved. The Department also acknowledged that there is ongoing work to be done including in relation to emergency accommodation:

We recognise that our programme of improvements must be continuous and that there is more for us to do. This includes our ongoing efforts to reduce the number of residents in emergency accommodation as well as the length of time that residents spend in emergency accommodation. As the Ombudsman rightly points out, it is impossible to predict accurately the demand for international protection. In the last two years we have seen significant increases in the number of new applicants and the consequent demand for our accommodation services. Much of our use of emergency accommodation could be eliminated if the more than 1,000 people who have been granted permission to remain in the State but continue to reside in Direct Provision accommodation could relocate into mainstream accommodation. We are working with Local Authorities and the City and County Managers Association to assist residents with this transition. We have also provided funding to the Peter McVerry Trust and DePaul Ireland as part of this process. ${ }^{251}$

\section{Support scheme for students in the protection process}

In June 2019, the Department of Education and Skills announced the extension for the fifth year of the student support scheme for access to third-level education for persons in the protection process for the academic year 2019/2020. This scheme offers student grant support for third-level courses to students in the broad international protection system - i.e. applicants for refugee status, applicants for subsidiary protection status and applicants at the leave to remain stage (other than those at the deportation order stage). In 2019, the eligibility criteria were reduced from five years in the Irish school system to three years. This brought the period of time in the Irish school system requirement of the scheme in line with the

250 Ibid., p. 11.

251 Department of Justice and Equality (23 April 2020) Statement by the Department of Justice and Equality on the Ombudsman's Commentary on Direct Provision 2019. Available at: www.gov.ie. 
requirements for the wider Student Grant Scheme. The IRC had called for this change in previous years. ${ }^{252}$ The change and the earlier announcement of the scheme in June were warmly welcomed by the IRC. ${ }^{253}$

Applicants were required to meet the following criteria:

- meet the definition of a protection applicant or a person at leave to remain stage (other than those at the deportation order stage);

- have obtained their Leaving Certificate;

- have been accepted on an approved post-leaving certificate course or an approved undergraduate course;

- have at least three academic years in the Irish school system by 31 August 2019;

- have been part of an application for protection or leave to remain for a combined period of three years as at 31 August 2019. ${ }^{254}$

\section{Daily expenses allowance}

The increases to the daily expenses allowance weekly rate to $€ 29.80$ for children and $€ 38.80$ for adults, which had been announced in October 2018, came into effect from 25 March 2019.

\section{Vulnerability assessments}

A group of eight NGOs (IRC, Children Rights' Alliance (CRA), Doras Luimní, Immigrant Council of Ireland, Nasc, Cultúr Migrants Centre, Movement of Asylum Seekers in Ireland (MASI) and Spirasi) called on the Government to introduce a vulnerability assessment identifying special reception needs at the beginning of the asylum procedure, arguing that this is a specific legal requirement following Ireland's transposition of the Reception Conditions Directive (2013/33/EU) into Irish law in June 2018. ${ }^{255}$ The IRC also published a report, The Reception Conditions Directive - one year on, in July 2019 highlighting this concern among others..$^{256}$

Responding to a parliamentary question on the issue of vulnerability assessment in July 2019, the Minister of State at the Department of Justice and Equality noted that a process for identification of special reception needs is in place, under the

252 Sheridan, A. (November 2019) Annual Report on Migration and Asylum 2018: Ireland, p. 82 Available at: www.emn.ie and www.esri.ie.

253 Irish Refugee Council (5 June 2019) 'Financial Supports introduced for Leaving Certificate students who are three years in the asylum process', Press Release. Available at: www.irishrefugeecouncil.ie.

254 Department of Education and Skills (4 June 2019) 'Ministers announce Student Support Scheme for Asylum Seekers to continue for coming year', Press Release. Available at: www.education.ie.

255 Irish Refugee Council (26 May 2019) 'Refugee organisations highlight absence of vulnerability assessment in Irish asylum procedure', Press Release. Available at: www.irishrefugeecouncil.ie.

256 Irish Refugee Council (12 July 2019) The Reception Conditions Directive - one year on. Available at: www.irishrefugeecouncil.ie. 
Reception Conditions Regulations 2018 within 30 days of presentation or application:

Once assessed as having special reception needs, there are a number of ways in which those needs are addressed. Tusla, for example, provides the required supports to meet the needs of unaccompanied minors once identified as such.

An initial interview is conducted with all applicants when they first attend the International Protection Office in Dublin. If the applicant indicates at that point that he or she requires accommodation, he or she will then be assessed for any specific reception needs. This assessment is taken into account when assigning accommodation to the particular individual.

As detailed in the Regulations, the Minister for Health and the HSE have lead responsibility in relation to health assessments. Applicants are invited for an initial health assessment on a voluntary basis.

There is a specific Health Screening Team funded and managed by the HSE located on the site of the Balseskin Reception facility for the purpose of assessing those who have just arrived in the State. The team comprises of GPs, a Medical Officer, a Clinical Nurse Specialist and two nurses, a primary care social worker, two primary care psychologists and clerical/administration support. This team offers a range of individual services and screening for medical and psychosocial needs with onward referral as necessary. The individual professionals communicate with RIA [Reception and Integration Agency] (within the bounds of patient confidentiality) if a particular need is identified that will affect the person's accommodation requirements. A new primary care facility will also open at Balseskin in the coming weeks, which will enable the health care team to provide services in a facility that is to the standard of all HSE primary care facilities.

In addition, arrangements are in place with Safetynet, who carry out health screening in various parts of the country on behalf of the HSE, to offer this screening service to those who do not, for whatever reason, avail of it in Dublin. Safetynet staff liaise with RIA if the person is deemed vulnerable on medical or related grounds. This can include a request that particular steps be taken as regards that person's accommodation.

There is on-going liaison between RIA and the HSE in relation to how best to meet the health and related needs of protection applicants. The HSE National Office for Social Inclusion has commissioned research to explore 
the concept of vulnerability with a view to further improving on the processes which are already in place. ${ }^{257}$

Speaking at the Joint Committee on Justice and Equality, Department officials indicated that they were meeting the legal requirements for vulnerability assessments but were working towards improvements. ${ }^{258}$ The UNHCR also pointed out that vulnerability assessment is provided for in the new National Quality Standards for accommodation centres (see Section 4.6.4) and that assessing the needs of asylum seekers is a new and evolving process:

While that is a new process and we will have to see how it will work out in practice, it has been incorporated into the standards. The intention is that upon arrival, people will be assessed for their reception needs, which will include access to medical services, counselling services and so on. On an ongoing basis, someone from a social care background in each reception centre will be tasked with ensuring that assessment is up to date and that no new needs have been identified. One can imagine that system working well if it was developed in co-operation with other service providers and Departments, along the lines indicated by Mr. Justice McMahon, namely, access to employment and mental health services, including specialist counselling services and others of a similar nature. That is not currently happening in any systematic way, but it is provided for in the legislation and included in the standards, and we hope it will become an important part of the system in the future. ${ }^{259}$

\section{Reception Conditions Directive: one year on}

The IRC published a briefing paper in July 2019 setting out its assessment of Ireland's implementation of the Reception Conditions Directive, one year on from the entering into force of the European Communities (Reception Conditions) Regulations $2018 .{ }^{260}$ The briefing paper was also based on case studies on the IRC's drop-in centre, outreach services and Independent Law Centre. It included the IRC's ongoing concerns about the lack of a formal vulnerability assessment, which it considers constitutes a breach of EU and Irish law. In the IRC's experience, it can take a lot of time and ongoing representations to ensure that a vulnerable person's reception needs are met, and there is no 'framework in place to sufficiently identify needs' ${ }^{261}$

257 Department of Justice and Equality (23 July 2019) Response to Parliamentary Question 33787/19. Available at: www.justice.ie.

258 Joint Committee on Justice and Equality (December 2019) Report on direct provision and the international protection process, p. 31. Available at: www.oireachtas.ie.

259 Ibid., p. 32.

260 IRC (July 2019) The Reception Conditions Directive: one year on. Available at: www.irishrefugeecouncil.ie.

261 Ibid., p. 19. 
The briefing paper also identified other issues, some of which were also highlighted by the Ombudsman in his 2019 commentary on direct provision (see above) and during the hearings held by the Joint Committee on Justice and Equality during 2019. These include concerns about the use of emergency accommodation, and access to schools and health services for residents in emergency accommodation. Delays in accessing the PPSN were also highlighted. The paper's recommendations included the ending of the use of emergency accommodation; the putting in place of a formal and detailed vulnerability assessment; and for the State to opt into the EU Asylum Procedures Directive. ${ }^{262}$

\subsubsection{Joint Committee on Justice and Equality report on the direct provision system}

The Oireachtas Joint Committee on Justice and Equality published a comprehensive report on the direct provision system in December 2019, calling for fundamental reform of the system. The report was based on public hearings with stakeholder groups, more than 140 written submissions, and visits by the Committee to direct provision accommodation centres in Mosney and Monaghan. The stakeholders invited to the public hearings were: Bryan McMahon (chair of the 2015 Working Group on the Protection Process); UNHCR; IRC; MASI; Nasc, the Migrant and Refugee Centre; CRA; Dr Liam Thornton of University College Dublin; and officials from the Department of Justice and Equality.

The Committee considered many issues including in relation to access to the labour market; the use of emergency accommodation; and assessments of vulnerable applicants for reception needs, which are referred to in the previous sections. $\mathrm{Dr}$ Bryan McMahon made the case to the Committee that the system has improved over time:

There have been many improvements in the system since the working group has made its report. It is not perfect but this is a changing space and this has to be monitored every year to see that the improvements are made. It was submitted that in 2017, the working group report was the first review of the analysis of the direct provision system since it was introduced, and membership of the group included representatives from every Department involved as well as non-governmental organisations, NGOs, working in the area and a number of academics and other experienced individuals. The report provides a valuable infrastructural analysis of the direct provision system and identifies many problems and issues of concern as well as suggesting reforms in many areas. Some of the recommendations were adopted and implemented fairly quickly while 
others were deferred. Even where there has been delay, however, the report has kept the direct provision question continuously on the political agenda. In any event, it is generally recognised that the programme of action set out in the report is still valid and is one that the Government is trying to implement. ${ }^{263}$

The Report made 43 conclusions and recommendations including:

- a shift towards provision of 'own-door' accommodation units and the involvement of approved housing bodies in providing accommodation and support services;

- the requirement in the tendering process to accommodate a minimum of 50 people per centre should be reduced to allow smaller providers and housing associations to provide accommodation;

- a central requirement in tenders should be that accommodation is situated in locations that maximise integration with local communities, and provide transport links, services, amenities and employment opportunities;

- extend labour market access for those eligible from six months to one year;

- comprehensive training courses and learning opportunities should be available for those unable to access the labour market or education;

- an individualised integration and transition plan for those granted status and leaving direct provision accommodation;

- establishment of a refugee advisory board to provide oversight and monitoring of all matters relevant to the international protection process and reception system. ${ }^{264}$

UNHCR Ireland welcomed the publication of the Joint Committee Report. One recommendation that UNHCR highlighted was the importance of early integration: 'introducing a legal requirement for local authorities to develop integration strategies for asylum applicants would help foster cohesive communities and promote diversity and equality'. ${ }^{265}$

\subsubsection{National Quality Standards for accommodation centres}

As reported for 2018, draft National Quality Standards for accommodation centres

\footnotetext{
263 Joint Committee on Justice and Equality (December 2019) Report on direct provision and the international protection process, p. 23. Available at: www.oireachtas.ie

264 Joint Committee on Justice and Equality (12 December 2019) 'Joint Committee on Justice and Equality report finds Direct Provision "not fit for purpose" and calls for fundamental reform of "flawed" international protection application process', Press Release. Available at: www.oireachtas.ie.

265 United Nations High Commissioner for Refugees (12 December 2019) 'UNHCR welcomes Oireachtas Committee report on Direct Provision and the International Protection Process', Press Release. Available at: www.unhcr.org.
} 
were issued for consultation in 2018. The draft National Standards are intended to meet the criteria set out in both European Asylum Support Office (EASO) Guidance on Operational Standards and Indicators and the Reception Conditions Directive (2013/33/EU). The Standards were agreed following an extensive consultative process with UNHCR and relevant NGOs and were published in August 2019. They are due to become binding in January 2021.

NGOs that had been involved in the consultation process, including Nasc and the CRA, welcomed the publication of the standards. ${ }^{266}$

The new standards include:

- independent living including access to cooking facilities;

- each centre will have a residents' charter, which describes the services available to children and adults living in the centre, including how and where the services are provided;

- continuous training is provided to staff in the centre to improve the service provided for all children and adults living in the centre;

- each centre will have a dedicated Reception Officer who is suitably trained to support all residents, especially people with special reception needs both inside the accommodation centre and with outside agencies. ${ }^{267}$

\subsubsection{Spending review on direct provision system}

In August 2019, the Department of Public Expenditure and Reform published an expenditure review on the direct provision system. The review was published as part of a series of 18 spending reviews across Government Departments. The spending review of the direct provision reception system was conducted by the Irish Government Economic and Evaluation Service (IGEES) unit of the Department of Justice and Equality with input from RIA and INIS. The Review noted that expenditure on direct provision accommodation was likely to reach $€ 120$ million in 2019, compared with €78 million in 2018. This increase was impacted by the increase in the number of applicants seeking accommodation; the quality standards improvements required of accommodation providers; and pressure on costs from the need to procure temporary emergency accommodation. The move to independent living (where applicants can cook for themselves, buying groceries on a points system in a food hall) and increased standards also impacted on daily

266 Nasc (16 August 2019) 'Nasc welcomes the launch and publication of the National Standards for Direct Provision', Press Release. Available at: www.nasc.org; Children Rights' Alliance (16 August 2019) 'National Standards for accommodation potentially transformative for families in the protection process but need for independent inspectorate essential for their success', Press Release. Available at: www.childrensrights.ie.

267 Department of Justice and Equality (22 November 2019) Statement on tenders for accommodation centres for international protection applicants. Available at: www.justice.ie. 
rates in centres to $€ 44$ per person per day in independent living centres in August 2019 compared to $€ 35.50$ per person per day in 2018 in all other commercial centres. The review noted that expenditure was likely to increase in the future, due to increased numbers of applicants and planned improvements to accommodation centres. $^{268}$

In 2019, the Department of Justice and Equality set up a high-level Interdepartmental Working Group to review the State's implementation of the Reception Conditions Directive (2013/33/EU). ${ }^{269}$ The Minister of State at the Department of Justice and Equality commented in relation to this group:
An Interdepartmental Group chaired by my Department, has been established to ensure that all Departments are proactively delivering on their responsibilities. The Group is reviewing the management of applicants for international protection and considering the short-to- medium term options which could be implemented to improve the system. ${ }^{270}$

\subsubsection{Establishment of expert group on direct provision system}

In December 2019, the Minister and Minister of State at the Department of Justice and Equality announced the establishment of the Expert Group on the Provision of Support, including Accommodation, to Persons in the International Protection Process (Asylum Seekers) chaired by Dr Catherine Day, former Secretary General of the European Commission. The membership of the expert group included relevant NGOs (Nasc, IRC and MASI). The expert group was due to report by the end of 2020 and had the following terms of reference:

- to advise on the development of a long-term approach to the provision of supports including accommodation to persons in the international protection process;

- to identify good practice in European countries in the provision of supports to persons within the international protection process, particularly dealing with variations in demand;

\footnotetext{
268 Department of Justice and Equality (15 August 2019) 'Ministers Flanagan and Stanton welcome publication of the Spending Review on Direct Provision', Press Release. Available at: www.justice.ie. Ibid. and Government of Ireland (28 December 2019) 'Ministers Flanagan and Stanton announce establishment of Expert Group on Direct Provision', Press Release. Available at: www.merrionstreet.ie.

270 Department of Justice and Equality (2 December 2019) 'Minister Stanton delivers Ireland's National Statement to CERD in Geneva', Press Release. Available at: www.justice.ie.
} 
- to set out a process for achieving the long-term approach to support persons in the international protection process. ${ }^{271}$

The Expert Group reported in September 2020 and the report will be discussed in the 2020 report of this series.

\subsection{CASELAW ${ }^{272}$}

\section{BS v Refugee Appeals Tribunal [2019] IESC 32}

The appellants were Albanian nationals who previously lived in Kosovo. They arrived in Ireland on 12 December 2014 and two days later they made an application for asylum. They did not disclose a full account of the circumstances of their arrival in Ireland, in particular that they had previously been issued with a visa for the United Kingdom. On 15 January 2015 the Office of the Refugee Applications Commissioner made an information request to the United Kingdom authorities under article 34 of the Dublin III Regulation (Regulation No. 643 of 2013), enclosing the fingerprints of the appellants with the request. On 12 February 2015 the United Kingdom authorities replied stating that pursuant to article 12(2) of the Dublin III Regulation, the United Kingdom was the Member State responsible for examining and determining their applications, on the basis that the appellants' fingerprints matched with persons who had been issued a multi-visit visa for the United Kingdom at its embassy in Warsaw in 2014.

The appellants subsequently brought judicial review proceedings alleging that the information request was unlawful for failing to set out the basis for the request as required by article 34 of the Dublin III Regulation. The Supreme Court rejected this challenge on the basis that the United Kingdom authorities had not raised any issue as to the basis for the request nor had they sought further information as to the grounds on which the request was made. The Supreme Court held that information requests pursuant to article 34 are not intended to require a lengthy account of the grounds for seeking the information, and in circumstances where both the Irish and United Kingdom authorities were well aware of the commonly occurring fact that asylum seekers arrive in Ireland having transited through the United Kingdom, it was unnecessary to expressly refer to this fact in the information request. The Supreme Court also rejected the appellants' argument that the Irish authorities acted in breach of article 34 in sending their fingerprints to the United Kingdom authorities with the relevant information requests, as well as the argument that the Irish authorities had breached the requirement to make 'take charge' requests

\footnotetext{
271 Government of Ireland (28 December 2019) 'Ministers Flanagan and Stanton announce establishment of Expert Group on Direct Provision', Press Release. Available at: www.merrionstreet.ie.

272 Case analysis by EMN legal consultant.
} 
in respect of the appellants as soon as possible. Accordingly, the appeals were dismissed.

\section{VU v Refugee Appeals Tribunal [2019] IECA 183}

This appeal concerned article 17 of the Dublin III Regulation, which vests in Member States the discretion to deal with an application for refugee status on humanitarian or compassionate grounds where Dublin III would otherwise have resulted in that application being transferred to another Member State. The issue concerned the identity of the appropriate national authority to exercise the article 17 discretion - whether it was the national authorities with responsibility for asylum decision-making, including Dublin appeals, or whether it was a sovereign power of the State exercisable only by the Minister for Justice. The High Court held that it was a sovereign power exercisable only by the Minister for Justice unless that power had been expressly delegated to the national asylum authorities, and that no such delegation had been provided for in Irish law.

The Court of Appeal disagreed and overturned the decision of the High Court. Baker J in the Court of Appeal set out the history of the Dublin system, including the need for a derogation arising from the migrant crisis in Greece in 2013/2014, and the previous reference from the High Court to the CJEU in MA $v$ International Protection Appeals Tribunal (Case C-661/17) EU:C:2019:53 in which the CJEU effectively held it was a matter for the Member States to determine which national authority was responsible for exercising the article 17 discretion. Baker J interpreted the national regulations (the European Union (Dublin System) Regulations, S.I. No. 525 of 2014) in the light of the CJEU decision in CK v Republika Slovenija (Case C-578/16 PPU) ECLI:EU:C:2017:127 and concluded that Irish law designated the national asylum authorities as having jurisdiction to exercise the article 17 discretion, and did not reserve the exercise of that sovereign discretion to the Minister for Justice. Accordingly, the appeal was allowed. The Minister for Justice has sought leave to appeal against this decision to the Supreme Court.

\section{MAM v Minister for Justice [2019] IECA 116}

The issue raised in these proceedings was effectively whether a refugee who subsequently acquires Irish citizenship by naturalisation lost the right to family reunification pursuant to section 18 of the Refugee Act 1996. The evidence before the court was that between 2010 and 2017 the Minister for Justice accepted applications for family reunification from refugees who had acquired Irish citizenship by naturalisation, but on foot of legal advice in 2017 the Minister reverted to the pre-2010 position that such persons lost their right to refugee family reunification upon naturalisation. The applicants challenged this position in judicial review proceedings. 
The High Court ([2018] IEHC 113) dismissed the applicants' challenge, and the applicants appealed. The Court of Appeal agreed with the High Court that in order to be eligible for refugee family reunification, a person must meet two requirements: first, be the holder of a declaration of refugee status, and second, that he or she continue to be a refugee within the meaning of the statutory definition. The Court of Appeal was satisfied that the refugee declarations which had previously been granted to the applicants had been revoked by operation of law once they acquired Irish citizenship and they were therefore no longer eligible for refugee family reunification. Accordingly, the appeal was dismissed. The appellants sought and were granted leave to bring a further appeal to the Supreme Court ([2019] IESCDET 206). ${ }^{273}$

\section{Agha v Minister for Social Protection [2019] IESC 82}

The appellants were Afghan nationals who arrived in Ireland in 2008. They lived in direct provision and had four children, three of whom were born in Ireland. The entire family applied for asylum in 2013. In December 2014, the Refugee Appeals Tribunal issued a decision declaring their youngest son to be a refugee and this was communicated to the family by letter dated 8 January 2015. Upon receipt of this decision, the entire family applied for family reunification and permission to remain in the State was granted in September 2015. The parents applied for child benefit in respect of all four children in February 2015 and were refused as they were deemed not to be habitually resident. They renewed this application in September 2015 and were successful following the grant of family reunification. The parents instituted proceedings arguing that child benefit was payable in respect of all children from the date of their application for refugee status in 2013 or, alternatively, in respect of their youngest son from the date of his recognition as a refugee in January 2015. The Court of Appeal found in favour of the parents ([2018] IECA 155).

The Minister for Social Protection was granted permission to bring a further appeal to the Supreme Court ([2018] IESCDET 204). The Supreme Court overturned the decision of the Court of Appeal and held that appellants were not entitled to child benefit from the date of the recognition of their youngest son as a refugee. The Supreme Court noted that child benefit is payable to a qualified person who normally resides with a qualified child where the qualified person is habitually resident in the State. A qualified person is not habitually resident in the State if they are not an Irish citizen, or a person who has been granted refugee status/subsidiary protection, or alternatively is not a person who has been given a permission to reside in the State. It was also noted that child benefit is payable by the State to help parents or those in loco parentis defray the costs associated with bringing up a child, but that it is not a payment made to a child or one that a child 
is entitled to receive. The criterion that must be fulfilled is that of habitual residence of the person to whom the child benefit is payable. The Supreme Court held that there is no difference of treatment between a qualified person who is a citizen, a person who has been declared to be a refugee or a person who has been granted permission to reside in the State or a person who is an EU citizen and is entitled to reside in the State by virtue of the right to free movement of EU citizens within the Member States. The State was entitled to have in place measures designed to prevent unlimited migration, and must be entitled to regulate the manner in which it provides for those in the State whose status has not yet been determined. Once a person is granted a permission to reside in the State or a grant of refugee status they are thereafter entitled to payment of child benefit as happened in this case. Therefore there was no basis upon which it could be said that there was any lack of equal treatment such as to give rise to a breach of Art. 40.1 of the Constitution. Accordingly, the Minister's appeal was allowed.

\section{B v International Protection Appeals Tribunal [2019] IEHC 763}

The applicant was an Albanian national who was stalked by a co-worker who vandalised her husband's car and subsequently fired shots at her husband. The appellant subsequently moved to Tirana but her stalker found her and further intimidated her there. The appellant claimed her stalker enjoyed political influence and/or protection in Albania so her complaints to the police were not effective, and therefore she fled Albania and claimed asylum in Ireland.

Almost all the elements of the applicant's claim were accepted by the International Protection Appeals Tribunal, which nonetheless rejected her appeal on the basis that there was no Convention nexus to her claim, and that she had not shown that effective State protection would be unavailable to her if she was to return to Albania. The applicant applied to the High Court for judicial review of the Tribunal decision.

The High Court found in favour of the applicant on the basis that the Tribunal had erred in its assessment of the impact of the fact that Albania has been designated as a safe country of origin in Irish law (by the International Protection Act 2015 (Safe Countries of Origin) Order 2018 (SI No.121/2018)). Barrett J noted that while a designation of a safe country of origin was not lightly made, and had practical and legal significance, the 2015 Act stated that a safe country of origin shall be considered to be a safe country of origin 'only where ... the applicant has not submitted any serious grounds for considering the country not to be a safe country of origin in his or her particular circumstances and in terms of his or her eligibility for international protection'. Barrett J was satisfied from the evidence before the court that the applicant had submitted such 'serious grounds', and that this was a more imposing feature of the case than the fact of designation simpliciter. 


\section{RC v Minister for Justice [2019] IEHC 65}

The applicant was a national of Afghanistan who was granted subsidiary protection in Ireland in 2016. He subsequently applied for family reunification for his wife, whom he married in 2017. The Minister for Justice refused the application on the basis that section 56(9)(a) of the 2015 Act only provided for refugee family reunification for spouses where the marriage pre-dated the application for international protection. The applicant subsequently instituted proceedings challenging the constitutionality and/or European Convention on Human Rights (ECHR) compatibility of the exclusion of post-flight marriages from the right to refugee family reunification.

The High Court held in the first instance that the applicant's challenge was premature in circumstances where an alternative remedy was available, namely an application for a visa pursuant to general immigration law as governed by the INIS Policy Document on Non-EEA Family Reunification. Humphreys J also rejected the applicant's complaint that the exclusion of post-flight marriages breached the constitutional guarantee of equality, holding that the distinction between pre- and post-flight marriages was legitimate and proportionate. Insofar as the European Court of Human Rights held otherwise in Hode \& Abdi v United Kingdom (2013) 56 EHRR 27, Humphreys J was satisfied that that decision should not be followed. Accordingly, he dismissed the applicant's proceedings.

The applicant in $R C$ did not appeal the decision, so the applicants in $A$ and $S v$ Minister for Justice [2019] IEHC 547 sought a hearing in the High Court on the basis that they would appeal the outcome to the Supreme Court. In $A$ and $S$ Barrett J declined to follow Humphreys $J$ in $A$ and $S$ on the basis that he was bound to follow Hode \& Abdi, and accordingly found that section 56(9)(a) of the 2015 Act was unconstitutional. The Minister for Justice was granted permission to appeal directly to the Supreme Court.

\section{II v Minister for Justice [2019] IEHC 729}

The applicant was granted refugee status as a minor on 25 September 2014. In July 2018 , when the applicant was aged 17 , an application for family reunification in respect of her mother, father and sister was submitted by her social worker. In September 2018 the application was refused by the Minister for Justice on the basis that it had not been submitted within 12 months of the grant of refugee status as required by section 56(8) of the International Protection Act 2015. The applicant then instituted proceedings challenging the constitutionality and ECHR compatibility of the 12-month time limit in section 56(8) of the 2015 Act, which does not permit extensions of time in any circumstances. In the applicant's case, she had not submitted the application within 12 months as the whereabouts of her family were unknown during that period. 
The High Court dismissed the challenge, holding that the applicant had failed to provide evidence that she was unable to submit the application within 12 months of the grant of refugee status. The High Court went on to address the applicant's substantive complaints in the event that this finding was incorrect. The High Court held in the first instance that the applicant should have availed of an available alternative remedy, namely applications for visas pursuant to general immigration law as governed by the INIS Policy Document on Non-EEA Family Reunification. Humphreys J went on to hold that it was not in breach of the Constitution to have a 12-month time limit for the making of an application for refugee family reunification, because there was no inherent constitutional right to family reunification for a person granted permission to reside in the State as a refugee. Even if there was such a right, Humphreys J was satisfied that the 12-month time limit was generous, and could not be said to be disproportionate. Humphreys J also rejected the complaint that the 12-month time limit was in breach of the ECHR, and therefore dismissed the proceedings. ${ }^{274}$

\section{IG v Minister for Justice [2019] IEHC 21}

The applicants were an Albanian mother and her two daughters whose applications for asylum were refused by the Refugee Applications Commissioner. They subsequently brought judicial review proceedings challenging the manner in which their applications had been processed by the Refugee Applications Commissioner, arising from the fact that the Commissioner had established a 'case processing panel of legal graduates' to perform 'case processing' in relation to applications for asylum and subsidiary protection. The applicants complained that the Refugee Act 1996 did not provide for delegation of the Commissioner's powers in this manner. The High Court (Barrett J) was satisfied that there was no breach of the statute in the manner of the investigation of the applicants' applications and accordingly dismissed the applications. The applicants were subsequently granted leave to appeal directly to the Supreme Court.

\section{X v Minister for Justice [2019] IEHC 284}

This case concerned whether, for the purposes of an application for family reunification by a beneficiary of subsidiary protection, 'child' could include a nonbiological child for whom the applicant had acted in loco parentis. Barrett J held that there is a wide diversity of familial structures and the relationship of father/child was not confined by the International Protection Act 2015 to a biological father, and accordingly quashed the Minister's refusal of family

274 On 21 January 2020 the Supreme Court granted the applicant leave to bring an appeal directly to that court ([2020] IESCDET 4). 
reunification. The Minister was subsequently granted leave to appeal directly to the Supreme Court ([2019] IESCDET 219).

UNHCR subsequently intervened in this case at the Supreme Court level as amicus curiae. The judgment will be discussed in the 2020 report of this series. 


\section{CHAPTER 5}

\section{Unaccompanied minors and other vulnerable groups}

\subsection{UNACCOMPANIED MINORS}

As reported in previous reports in this series, Tusla, the Child and Family Agency, was established under the Child and Family Agency Act 2013 as an independent legal entity. The Agency, which is overseen by the Department of Children, Equality, Disability, Integration and Youth, ${ }^{275}$ brings together key services relevant to children and families including child protection and welfare services previously operated by the Health Service Executive (HSE), the Family Support Agency and the National Educational Welfare Board. The Social Work Team for Separated Children Seeking Asylum is a dedicated and bespoke service within Tusla. Separated Children Services provides care, family reunification and aftercare support to separated children seeking asylum with an 'equity of care' principle applied to all unaccompanied minors (UAMs) who are in receipt of the services. ${ }^{276}$

\subsubsection{Statistics}

\section{Referrals to Tusla}

A total of 184 referrals of UAMs were made to the Social Work Team for Separated Children Seeking Asylum (SCSA) of Tusla in 2019. Of these, 128 identified as male and 56 as female. ${ }^{277}$ Some 113 UAMs were placed in care. ${ }^{278}$

\section{Applications for international protection}

A total of 49 unaccompanied minors made applications for international protection in 2019, as compared to 17 applications in 2018. Of the 2019 applicants, 35 were male and 14 were female. ${ }^{279}$

Providing care for UAMs is also the responsibility of the Social Work Team for SCSA. Tusla may decide that an application for international protection should be made on behalf of the UAM. Where Tusla decides that is in the best interests of the child that an application for international protection is made on their behalf, specific arrangements will be made by the International Protection Office (IPO) in conjunction with Tusla for the processing of the application. Tusla will support the minor throughout the process, including attending at their interview.

\footnotetext{
In 2019, Department of Children and Youth Affairs. Department name was changed in November 2020. Correspondence with Tusla, November 2020.

Correspondence with Tusla, August 2020.

Correspondence with Tusla, February 2020

Correspondence with International Protection Office, April 2020.
} 


\section{Unaccompanied minors from Malta and Greece}

In January 2019, Ireland pledged to accept five UAMs from Malta, following discussions with the European Commission and the Maltese authorities. These UAMs were part of a group of 298 migrants disembarked in Malta as a result of search and rescue missions in the Mediterranean. ${ }^{280}$ Of these minors, four had arrived by the end of 2019. ${ }^{281}$

As reported for 2018, Ireland committed to accepting 36 UAMs for Greece on a bilateral basis in December 2018. A Tusla-led mission to Athens took place in September 2019 and eight minors were assessed, screened and approved for relocation to Ireland. These eight minors had not arrived in Ireland by the end of 2019. ${ }^{282,283}$

The Tusla Annual Report 2019 provides details on some the activities of the Social Work Team for SCSA during 2019. For example, the report noted that the SCSA team was supported and resourced to meet requirements under the Irish Refugee Protection Programme (IRPP); all social workers were trained in November 2019 on the Tusla/SCSA-specific Child Protection Risk Assessment for the purposes of age assessment in relation to implementation of the Child Care Act 1991 as amended; 98 per cent of aftercare clients are engaged in some form of education or training and many children in care are going forward for third-level education. ${ }^{284}$

\subsection{OTHER VULNERABLE GROUPS}

\subsubsection{Migrant children}

\section{Children's Rights Alliance Report Card}

The annual Children's Rights Alliance (CRA) report card covering $2019^{285}$ marked the developments for refugee and asylum-seeking children as a ' $\mathrm{C}+$ ': an improvement on the ' $C$ ' grade for this category in 2018. ${ }^{286}$ This was the final report card under the Programme for a Partnership Government 2016 - 2020. It based its grading on Government commitments in relation to offering a safe haven for refugees and reforming the direct provision system.

The grade awarded reflected progress in relation to resettlement with the commitments to accept further refugees made in December 2019 under a new

Department of Justice and Equality (9 January 2019) 'Minister Flanagan and Minister Stanton agree to invite unaccompanied minors to Ireland in solidarity with Malta', Press Release. Available at: www.justice.ie.

See Irish Refugee Protection Programme page updated 18 August 2020. Available at: www.justice.ie.

Correspondence with Department of Justice and Equality, March 2020.

The transfer process was impeded most notably by the advent of the COVID-19 coronavirus pandemic; however, the UAMs did eventually arrive in June 2020 with full refugee status. Correspondence with Tusla, November 2020.

Tusla (June 2019) Tusla Annual Report 2019, p. 23. Available at: www.tusla.ie.

Children's Rights Alliance (March 2020) Report Card 2020. Available at: www.childrensrights.ie.

The Report Card 2020 looks at developments over 2019 and the Report Card 2019 looks at developments over 2018. 
phase of the IRPP; the increase in the weekly direct provision payment for children in March 2019; and the publication of the National Standards for Accommodation Centres. However, the report card expressed concerns about the inappropriateness of emergency accommodation for children. ${ }^{287}$

The report also made reference to concerns expressed by the Ombudsman for Children in relation to access to education for children in Emergency Reception and Orientation Centres (EROCS), and recommended that children be placed in local mainstream schools as soon as possible to ensure equity of outcomes. ${ }^{288,289} \mathrm{It}$ reported that significant improvements had been made in the EROC school system during 2019. ${ }^{290}$

In relation to direct provision, a significant concern, echoing other commentators (see Chapter 4) was the suitability of emergency accommodation for children and families. The Report Card also emphasised the role of the National Standards for Accommodation Offered to People in the Protection Process published in 2019 in ensuring that: 'refugee and asylum-seeking children receive a consistent standard of high-quality care in all accommodation centres irrespective of location. Several standards address the rights and needs of children and service providers are obliged to act in the best interests of the child. ${ }^{291}$ Indicators in the standards to meet these aims include the provision of own-door accommodation with access to private living space and separate sleeping quarters for families; access to cooking and storage facilities in centres; and explaining children's rights in an ageappropriate way. ${ }^{292}$

\section{Ombudsman for Children Office consultation with children living in direct provision}

Arising from the outreach work carried out by the Ombudsman for Children Office (OCO) with children living in direct provision centres since the remit of the OCO extended to direct provision in 2017, the OCO made a commitment in its Strategic Action Plan 2019-2021 to undertake a consultation with children living in direct

Children's Rights Alliance (March 2020) Report Card 2020, p. 5. Available at: Www.childrensrights. ie

The report card noted that in general, primary-age schoolchildren are provided with onsite education for three months and moved to mainstream schools thereafter, provided they are school ready. Post-primary schoolchildren are placed in mainstream schools as soon as possible, which the Report Card noted as a welcome development. Ibid., p. 136.

Findings of Joint Inspectorate and National Educational Psychological Service (NEPS) Visits to Education Settings in Emergency Reception and Orientation Centres (EROCS) were published in June 2018. The report and responses to the recommendations are available at: www.gov.ie.

Ibid., p. 137.

Ibid., p. 138.

Standard 4.4 provides that: 'The privacy and dignity of family units is protected and promoted in accommodation centres. Children and their care-givers are provided with child friendly accommodation which respects and promotes family life and is informed by the best interests of the child.' Indicators under this standard by which a service provider may be judged to have met the standard include the provision of private living space with separate sleeping quarters, and own-door accommodation for families. Department of Justice and Equality (15 August 2019) National Standards, p. 35. Available at: www.justice.ie. 
provision accommodation. The consultation was carried out between July and October 2019, when OCO staff met with 73 children aged 12 to 17 years living in nine accommodation centres across Ireland. Each centre was visited on three occasions, first to meet with children and their parents to explain the consultation process and to obtain consent. Focus groups were held on the second visit on children's rights and changes children wanted to see, and some children participated in individual interviews. The third visit followed up to get participants' feedback on the initial analysis of the findings. The OCO also held two full-day creative sessions with participants in November 2019, at which they engaged in various art activities and gave anonymised interviews to camera. The findings of this research will be published in a report in $2020 .{ }^{293}$

\section{Undocumented children}

The Migrant Rights Centre of Ireland (MRCl) published the results of a research survey undertaken by them with 108 parents of undocumented children in Ireland in July 2019. Statistics from the study included that, of the 185 children whose parents completed the survey, 68 per cent were born in Ireland and 32 per cent outside Ireland. Of those born outside Ireland, 78 per cent had lived in Ireland for more than five years, with some living in Ireland for more than 16 years. ${ }^{294}$

$\mathrm{MRCl}$ notes that Ireland has not yet implemented the recommendations of the UN Committee on the Rights of the Child (UNCRC) in its Concluding Observations to Ireland from 2016, in relation to children in situations of migration. ${ }^{295}$ These recommendations included that the State party provide 'clear and accessible formal procedures for conferring immigration status on children and their families who are in irregular migration situations'. ${ }^{296}$

\subsubsection{Migrant women}

\section{Sexual and gender-based violence}

Two pieces of related legislation were enacted during 2019 in relation to violence against women and domestic violence. The Criminal Law (Extraterritorial Jurisdiction) Act $2019^{297}$ gives effect to certain aspects of the Istanbul Convention on preventing and combating violence against women and domestic violence and extends the criminal law of the State to certain conduct engaged in outside the State. Sections 1 and 3 provide for extraterritorial jurisdiction over certain 'relevant offences' including murder, manslaughter, rape, and sexual assault

Office of the Ombudsman for Children (September 2020) Annual Report 2019. Available at: WwW.oco.ie Migrant Rights Centre of Ireland ( 3 July 2019) 'New survey gives unprecedented picture of undocumented children and young people in Ireland', Press Release. Available at: www.mrci.ie. Correspondence with $\mathrm{MRCl}$, November 2020.

United Nations Committee on the Rights of the Child (1 March 2016) Concluding Observations Ireland, CRC/C?IRL/CO/3-4, paragraph 67 and paragraph 68 (a) (b) and (c). Available at: https://docstore.ohchr.org. No. 6 of 2019. 
offences under section 3, 4, 5, 9 or 10 of the Non-Fatal Offences Against the Person Act 1997 in accordance with Article 44 of the Istanbul Convention. Section 4 amends the Criminal Justice (Mutual Assistance) Act 2008 to provide for the application of the provisions of that Act to the Istanbul Convention. Following this legislation, Ireland ratified the Istanbul Convention on 8 March 2019. The Council of Europe Convention on Preventing and Combating Violence Against Women and Domestic Violence (Privileges and Immunities) Order $2019^{298}$ accords various privileges and immunities to the group of experts on action against violence against women and domestic violence (GREVIO) established pursuant to Article 66 of the Council of Europe Convention on preventing and combating violence against women and domestic violence and other members of delegations carrying out country visits as set forth in Article 68, paragraphs 9 and 14 of the Convention, pursuant to the Diplomatic Relations and Immunities Act 1967 (as amended). ${ }^{299}$

\section{PROTECT project - Preventing sexual and gender-based violence against migrants and strengthening support to victims}

International Organization for Migration (IOM) Ireland produced Responding to sexual and gender-based violence - Guidance for International Protection Accommodation Centre Managers and Personnel as part of the PROTECT (Preventing sexual and gender-based violence against migrants and strengthening support to victims) project 2019/2020. This project is funded under the European Union's Rights, Equality and Citizenship Programme (2014-2020). IOM Ireland participates in this project with IOM offices from 11 other EU Member States Belgium, Bulgaria, Croatia, Greece, Hungary, Italy, Malta, the Netherlands, Poland, Slovenia and Spain. ${ }^{300}$

The Guidelines take account of the recommendations made in the Istanbul Convention on preventing and combating violence against women and domestic violence. The guidelines were drawn up in consultation with migrant women living in international protection accommodation centres as well as organisations working in the area of sexual and gender-based violence and/or migrant communities. Focus group consultations were undertaken with women living across nine accommodation centres.

IOM views these guidelines as a practice-based companion to policy documents already available to centre staff and as a follow-up to capacity-building training 
delivered as part of the PROTECT project. It notes that they could also be applied in a broader migratory context. ${ }^{301}$

The Guidelines recognise that a range of framework documents addressing this topic are already in place in Ireland, including the Migrant Integration Strategy, the Department of Justice and Equality Domestic Violence Immigration Guidelines and the RIA [Reception and Integration Agency] Policy and Practice Document on safeguarding RIA residents against Domestic, Sexual and Gender-based Violence and Harassment 2014, as well as Children First rules on safeguarding children. ${ }^{302}$

The consultation found that suggestions made by migrant women echoed the recommendation of the United Nations Convention Against Torture (UNCAT) Committee on Ireland from 2017 that highlighted the need to: 'provide mandatory training on gender-based and domestic violence for police and other law enforcement officials, social workers, lawyers, prosecutors, judges, and other public officials dealing with victims of gender-based including domestic and sexual violence' ${ }^{303}$

The report outlined that three factors particularly influence the experience of victims of gender-based violence in a migratory context - that there is a need for a survivor-centred approach; that sexual and gender-based violence (SGBV) has an intercultural dimension and there needs to be sensitivity to this, and that victims of SGBV often experience complex trauma. Therefore, IOM recommended that all work with survivors should be based on three principles - to be survivor-centred, have an intercultural approach and be trauma-informed. ${ }^{304}$ 


\section{Borders, visas, irregular migration and return}

\subsection{BORDERS}

\subsubsection{Refusals of leave to land}

According to Eurostat, a total of 7,455 people were refused permission to enter Ireland in 2019. This was an increase of 55 per cent over 2018, when there were a total of 4,795 refusals of entry. ${ }^{305}$

Albanian nationals accounted for the most refusals of entry in 2019, with 1,730 refusals, an increase of 179 per cent from the 620 refusals in 2018, according to Eurostat rounded figures. Ireland accounted for 7.5 per cent of refusals of entry for Albanian nationals across the EU-28 as a whole $(22,985)$, and was the fifth highest country after Greece, Italy, Croatia and Hungary. The other top countries for refusals of entry in Ireland were Brazil, South Africa, Bolivia and Georgia. Together these made up 48 per cent of all refusals of entry for 2019. Table 6.1 shows refusals of entry for the top 5 nationalities, compared with total refusals of entry for these nationalities in the EU-28.

TABLE 6.1 REFUSALS OF ENTRY AT EXTERNAL BORDER IN IRELAND 2019

\begin{tabular}{|l|l|l|l|l|}
\hline Country & $\begin{array}{c}\text { Refusals of entry, } \\
\mathbf{2 0 1 8}\end{array}$ & $\begin{array}{c}\text { Refusals of entry, } \\
\mathbf{2 0 1 9}\end{array}$ & $\begin{array}{c}\text { \% of refusals EU- } \\
\mathbf{2 8 , 2 0 1 9}\end{array}$ & $\begin{array}{c}\text { Order EU-28, 2019 } \\
\text { (from highest) }\end{array}$ \\
\hline Albania & 620 & 1730 & 7.5 & Fifth \\
\hline Brazil & 525 & 720 & 8.2 & Third \\
\hline South Africa & 360 & 580 & 73 & First \\
\hline Bolivia & 230 & 275 & 48 & first \\
\hline Georgia & 220 & 275 & 5.76 & Sixth \\
\hline
\end{tabular}

Source: Eurostat: Third country nationals refused entry at the external borders - annual data (rounded)[migr_eirfs], data extracted 11 October 2020.

The Department of Justice has clarified the process around refusals of entry:

Responding to emerging trends of illegal entry to the State is an integral part of the work of all Border Management agencies and Ireland is no

305 Eurostat, Third country nationals refused entry at the external borders - annual data (rounded) [migr_eirfs], data extracted 10 October 2020. Available at: https://ec.europa.eu/eurostat. 
different in that regard. The Border Management Unit works with other Border Forces, Airlines and the Garda National Immigration Bureau to address such illegal entry. There is a direct correlation between the extent of attempted illegal entry to the State and the actual numbers of refusals as the State carries out its duties of protecting its borders. This does not signify any change of policy, but rather the outcome of increases in differing patterns of illegal immigration over time.

In particular, it works closely with its UK colleagues to protect the external perimeter of the Common Travel Area and to prevent intra-CTA illegal movements.

The following table provides a breakdown of the reasons for refusal of leave to land for the 6,109 refusals recorded at Dublin Airport in 2019. It should be stressed that the table shows the first reason for refusal and in many cases there will be multiple reasons for refusals.

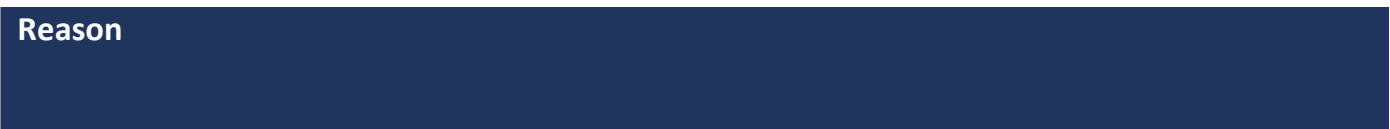

Sec. 4.3(a) That the non-national is not in a position to support himself or herself and any accompanying dependants

Sec. 4.3(b) That the non-national intends to take up employment in the State but is not in possession of a valid employment permit

Sec. 4.3(c) That the non-national suffers from a condition set out in Schedule 1 of the 2004 Immigration Act

Sec. 4.3(d) That the non-national has been convicted either in the State or otherwise, of an offence that may be punished under the law of conviction by imprisonment for one year or by a more severe penalty

Sec. 4.3(e) That the non-national, not being exempt, by virtue of an order under Section 17, from the requirement to have an Irish visa, is not the holder of a valid Irish visa

Sec. 4.3(f) That the non-national is the subject of:

(i) a deportation order;

(ii) an exclusion order; or

(iii) a determination by the Minister that it is conducive to the public good that he or she remain outside of the State

Sec. 4.3(g) That the non-national is not in possession of a valid passport or equivalent document issued by or on behalf of an authority recognised by the Government, which establishes his or her identity and nationality

Sec. 4.3(h) That the non-national:

(i) intends to travel whether immediately or not to Great Britain or Northern Ireland; and

(ii) would not qualify for admission to Great Britain or Northern Ireland if he or she arrived there from a place other than the State

Sec. 4.3(i) That the non-national having arrived in the State in the course of employment as a seaman has remained in the State without the leave of an Immigration Officer after the departure of the ship in which he or she arrived 
Sec. 4.3(j) That the non-national's entry into or presence in the State could pose a threat to national security or be contrary to public policy

Sec. 4.3(k) That there is reason to believe that the non-national intends to enter the State for the purposes other than those expressed by the non-national

Sec. 4.3(I) That the non-national:

(i) is a person to whom leave to enter or leave to remain in a territory other than the State of the common travel area (within the meaning of the 2005 International Protection Act) applied at any time during the period of 12 months immediately preceding his or her application in accordance with Section 2, for a permission;

(ii) travel to the State from any such territory; and

(iii) enter the State for the purpose of extending his or her stay in the said common travel area regardless of whether or not the person intends to make an application for international protection.

Total

Source: $\quad$ Department of Justice, November 2020.

Requests for international protection made at ports of entry are processed in accordance with the law as set out in the International Protection Act 2015. The Department engages on a regular basis with the UNHCR on all matters relating to International Protection. ${ }^{306}$

Non-governmental organisation (NGOs) including the Irish Refugee Council (IRC) and the Immigrant Council of Ireland (ICl) have previously expressed concerns about availability of disaggregated data showing the reasons for refusals of entry, for example in the IRC's submission to the UN Convention Against Torture (UNCAT) in 2017. ${ }^{307}$ In its Concluding Observations to Ireland on its second periodic report to the committee in 2017, the UNCAT asked Ireland to provide the Committee in its next report 'with data on the countries of origin of the persons denied leave to land and their point of embarkation for the State party, to which they were returned'. ${ }^{308}$

The Irish Times reported in 2019 regarding checks being conducted at point of exit from the aircraft. ${ }^{309}$ The IRC noted in its Asylum Information Database (AIDA)

306 Correspondence with Immigration Service Delivery, Department of Justice, November 2020.

307 For example, in the IRC submission to the UNCAT in 2017: see Sheridan, A. (2018) p. 14. Available at: www.emn.ie and www.esri.ie; also IRC (June, 2020) AIDA Update, pp. 21-22. Available at: www.asylumineurope.org; ICI (29 July 2020) 'Huge cracks in immigration system magnified during Covid-19', Press Release. Available at: www.immigrantcouncil.ie. UNCAT (31 August 2017) Concluding observations on the second periodic report of Ireland CAT/C/IRL/CO/2. Available at: http://docstore.ohchr.org.

309 Lally, C. and F. Kelly (31 December 2019) 'Immigrant airport checks revised over destruction of fake papers', Irish Times Available at: www.irishtimes.com 
report for 2019 that it wrote to the Minister for Justice in 2020 seeking clarification. The IRC states that the Department replied that:

the purpose of checks on arrival was to determine if a person is allowed leave to land rather than any assessment of asylum. The response added that checks conducted at the point of exit from the plane have always been a part of immigration control and as a standard procedure it complies with all legal obligations not impeding persons from claiming asylum.

\subsubsection{Border control systems and technology}

\section{Common Travel Area checks}

Immigration controls at points of entry into the State are undertaken by the Immigration Service Delivery Border Management Unit at Dublin Airport and by members of An Garda Síochána at all other points of entry, which include airports, seaports and the land border. It is the responsibility of the relevant District and Divisional Officers to put in place immigration controls along the border with Northern Ireland. Citizens of the Common Travel Area (CTA) are entitled to free movement between the two states; however, immigration controls are available to be put in place along the border in order to detect and prevent persons entering the Irish State illegally.

While there are no permanent physical border controls along the border with Northern Ireland, from time to time mobile immigration controls are put in place to detect and prevent illegal entrants to the State. These are not passport controls; they are immigration controls. Any identified EU national or UK and Irish national has free movement and is not prevented from travelling into this State.

The powers utilised to examine documents by An Garda Síochána, when such immigration controls are put in place, are in accordance with immigration legislation. ${ }^{310}$

As of 31 October 2019, 158 illegal immigrants had been detected attempting to enter the State illegally via Northern Ireland. ${ }^{311}$

\section{E-gates}

The E-gates for passport control at Dublin Airport were officially opened by the Minister for Justice and Equality in June 2019. In May 2019, all the E-gates were upgraded to feature flatbed readers that are compatible with the Irish Passport

\footnotetext{
310 Correspondence with Border Management Unit, Immigration Service Delivery, Department of Justice and Equality, February 2020.

311 Department of Justice and Equality (20 November 2019) Response to Parliamentary Question 47532/19. Available at: www.justice.ie.
} 
Card. E-gates have been deployed at Dublin Airport since December 2017 - there are 10 e-gates in each of Terminals 1 and 2 and five in the new Transfers area. ${ }^{312}$ In opening the new e-gates, the Minister for Justice and Equality noted that a combination of manned passport booths and e-gates would continue to be available to passengers. ${ }^{313}$

Over 3.3 million passengers successfully used the e-gates at Dublin Airport in 2019. ${ }^{314}$

The Department of Justice and Equality noted certain actions to improve effectiveness at external borders during 2019, including:

- increased usage of the Advanced Passenger Information System to monitor incoming extra-EU flights;

- upgrades to the E-gates system that facilitate greater monitoring efficiencies.

Immigration Control Officer and Immigration Control Supervisor recruitment campaigns were also undertaken during the year. ${ }^{315}$

\section{New Garda station, office accommodation and detention facilities at Dublin Airport}

As reported for $2018,{ }^{316}$ plans were progressed for the redevelopment of the Transaer Building at Dublin Airport. This redevelopment provides for the refurbishment of an existing facility for use as a Garda station, with office accommodation and detention facilities. Work was expected to be completed for May 2019; however, as of February 2020, the phased opening of the Garda Station was scheduled for March 2020. ${ }^{317}$

\subsection{VISAS}

\subsubsection{Visa statistics}

Provisional figures indicate that approximately 155,760 entry visa applications (including both short and long stays) were received in 2019, an increase of 10.77

\footnotetext{
312 Correspondence with Border Management Unit, Immigration Service Delivery, Department of Justice and Equality, February 2020.

313 Department of Justice and Equality (1 June 2019) 'Minister Flanagan officially opens new eGates in Dublin Airport', Press Release. Available at: www.inis.gov.ie.

314 Correspondence with Border Management Unit, Immigration Service Delivery, Department of Justice and Equality, February 2020.

315 Ibid.

316 Sheridan, A. (November 2019) Annual Report on Migration and Asylum 2018: Ireland, p.120. Available at: www.emn.ie and www.esri.ie.

317 Correspondence with Border Management Unit, Immigration Service Delivery, Department of Justice and Equality, February 2020.
} 
per cent on 2018, and a cumulative increase of 59.92 per cent over the 2013 figure. The approval rate for entry visa applications was 89.5 per cent. The top five nationalities applying for visas in 2019 were: India $(36,275)$; People's Republic of China (23,502); Russian Federation $(18,506)$; Nigeria $(8,372)$ and Turkey $(6,281)$.

The number of visas granted was 137,207 , of which 108,595 were ' $C$ ' short stay and 28,612 were ' $D$ ' long stay. ${ }^{318}$

\subsubsection{Abolition of re-entry visa system}

Ireland abolished its re-entry visa system with effect from 13 May 2019. This system had required third-country nationals from visa-required countries who were legally resident in Ireland and had registered their residence with the immigration authorities to apply for a re-entry visa to travel to and from Ireland. The re-entry visa was applied for from within the State. From 13 May 2019, holders of an Irish Residence Permit (IRP) card or the former Garda National Immigration Bureau (GNIB) card are exempt from the requirement to hold a visa. The Department of Justice and Equality noted: 'The IRP card is the standard EU format for residence permits and is recognised by airlines. Improvements in security in the IRP has made it possible to eliminate the need for re-entry visas, without compromising the safety and security of the visa or immigration system.' The Minister for Justice and Equality also noted that this initiative was part of a series of planned improvements to customer service in the immigration area. ${ }^{319}$

The new system does not remove the requirement for visa-required nationals to apply for a visa in advance of travel to Ireland. ${ }^{320}$

A small number of categories of third-country nationals from visa-required countries, including children between the ages of 0 and 15, who do not hold GNIB/IRP cards, were still required to have re-entry visas. ${ }^{321}$

\subsubsection{New five-year multi-entry tourist visa option for China nationals}

In June 2019, Ireland announced a new five-year multi-entry tourist visa option for China nationals, which became available from 1 July 2019. Previously one-year, two-year and three-year tourist visa options were available. The five-year multientry option was already available to business visitors. The five-year multi-entry tourist visa option will be available 'where the applicant has a proven reliable travel

\footnotetext{
318 Correspondence with Visa Division, Immigration Service Delivery, Department of Justice and Equality, February 2020 and June 2020.

319 Department of Justice and Equality (12 April 2019) 'Minister Flanagan announces abolition of re-entry visa system', Press Release. Available at: www.inis.gov.ie.

320 Ibid.

321 Department of Justice and Equality (updated 30 May 2019) 'Abolition of adult re-entry visas'. Available at: www.inis.gov.ie.
} 
history as evidenced by a visa previously granted by Ireland, the United Kingdom, the Schengen States, Australia, Canada, New Zealand or the USA and compliance with the terms of those visas'.322

The announcement was made on the 40th anniversary of the establishment of diplomatic relations between Ireland and China, and in the context of Tourism Ireland's commitment to growing the Chinese travel market in future years. According to the Department of Justice and Equality:

China is the largest outbound travel market in the world and one that Tourism Ireland is committed to growing over the coming years. The current approval rate for Chinese visitor visas to Ireland is over 95 per cent and the Visa Office in the Irish embassy in Beijing issued over 7,500 visitor visas in 2018. Tourism Ireland aims to grow Chinese visitor numbers to 200,000 by 2025 and, in particular, to grow the number of high-end individual Chinese travellers to the island of Ireland. The latest change to the visa regime will be a major support in growing this important tourism market. $^{323}$

\subsection{IRREGULAR MIGRATION}

\subsubsection{Operation Vantage}

As reported in previous years, Operation Vantage was set up on 10 August 2015 by the Garda National Immigration Bureau (GNIB) to investigate illegal immigration and identify marriages of convenience as defined under the Civil Registration (Amendment) Act 2014.

A multi-agency day of action took place on 5 March 2019 to target abuses of immigration legislation and processes around public service licence vehicles (PSVs). The operation was led by GNIB and supported by supported by members attached to Special Crime Operations, Roads Policing, Dublin Metropolitan Region (DMR) West Traffic Corps, the Carriage Office, the Garda Analyst Service, the Irish Naturalisation and Immigration Service, the Department of Social Protection and the National Transport Authority.

This was the latest phase of an investigation under Operation Vantage which, according to the Garda authorities, had at that date (5 March 2019) 'uncovered a total of one hundred and thirty four (134) cases where the PSV licence holder or PSV applicant is subject to ongoing investigation where the immigration status of 
the individual is of concern' ${ }^{324}$

Following the searches, a further 15 persons were 'identified for investigation where marriage of convenience and fraud has been uncovered. Seven further persons were found to be present in the State without any immigration permission. ${ }^{325}$

\subsubsection{Migrant smuggling}

\section{Death of 39 persons in refrigerated truck in Essex, United Kingdom}

The GNIB co-operated with the investigation undertaken by the Essex constabulary into the incident in which 39 persons were discovered dead in a refrigerated truck outside Tilbury Port, Essex on 23 October 2019. According to the December 2019 report of the Garda Commissioner to the Policing Authority, ${ }^{326}$ the Garda Commissioner signed a request to participate in a Joint Investigation Team received from the Belgian and UK authorities. ${ }^{327}$

\section{Persons discovered in refrigerated truck at Rosslare port}

Sixteen men (14 adult males and two juveniles) ${ }^{328}$ were found in a truck at Rosslare ferry port in November 2019. According to media reports, the men had boarded the truck before it left Cherbourg, France, and were believed to be originally from Iran or Iraq. ${ }^{329}$ Speaking during an interview on RTÉ, the Minister for Justice and Equality said it was important that security be tightened at all ports in light of the incident. He also expressed concerns that 'Ireland is a focus of attention as something of a back door to the UK'. In stressing the importance of north-south co-operation, he hoped that An Garda Síochána and the Police Service of Northern Ireland (PSNI) would work in a 'seamless way to ensure we don't have a border situation that is seen as easy access'. ${ }^{330}$

The IRC commented on the incident and said that people would continue to risk their lives in this fashion in the absence of more safe and legal pathways to avoid persecution:

\footnotetext{
324 An Garda Síochána (5 March 2019) 'Multi agency day of action to target abuses of immigration and PSV legislation on the $5 / 3 / 19$ ', Press Release. Available at: www.garda.ie.

Ibid.

An Garda Síochána provides a monthly report to the Policing Authority outlining the key aspects of the administration and operation of An Garda Síochána, in accordance with Section 41A of the Garda Síochána Act 2005, as amended.

327 An Garda Síochána (December 2019) Monthly Report to the Policing Authority - In accordance with Section 41A of the Garda Síochána Act 2005 (as amended), p. 19. Available at: www.garda.ie.

328 RTÉ (22 November 2019) 'Security must be tightened at Irish ports, says Flanagan'. Available at: www.rte.ie.

329 Lally, C., J. Horgan-Jones and H. McGee (21 November 2019) 'Migrants found on Rosslare-bound ferry "thought they were going to UK"', Irish Times. Available at: www.irishtimes.com. 
Without more proactive responses and solutions which open up safe and legal ways for people to escape persecution we will continue to see people making journeys of this nature ... No person should find themselves in a situation where they feel that their only choice is to pay smugglers to transport them on dangerous and arduous journeys with no guarantees for their safety. ${ }^{331}$

\subsection{RETURN}

\subsubsection{Return statistics}

According to rounded Eurostat data, a total of 2,535 persons were ordered to leave in 2019. ${ }^{332} \mathrm{~A}$ total of 298 deportation orders was effected in 2019,,33 up from 163 in 2018. ${ }^{334}$ The top nationalities for deportation orders effected were Pakistan, Nigeria, Albania, China (including Hong Kong) and Georgia. ${ }^{335}$

In addition, there were 30 outgoing transfers under the Dublin III Regulation in 2019. A total of $65 \mathrm{EU}$ nationals were also returned to their home countries on foot of EU removal orders in 2019. ${ }^{336}$

There was a total of 255 voluntary return cases in relation to third-country nationals in 2019, 106 of whom were assisted by the International Organization for Migration. ${ }^{337}$

According to rounded Eurostat data, 55 persons under 18 years were returned following an order to leave in 2019. ${ }^{338}$

\subsubsection{Co-operation with Frontex}

In December 2019, Ireland led a Frontex Joint Return Operation in co-operation with Belgium and Iceland. As the Frontex Regulation (2019/1896) constitutes a

331 Ó Fátharta, C. (22 November 2019) “"Asylum seekers will continue to risk their lives”: Irish Refugee Council call for "real" action', Irish Examiner. Available at: www.irishexaminer.com

332 Eurostat, 'Third country nationals ordered to leave, annual data (rounded)', [migr_eiord]. Data extracted 11 October 2020. Available at: https://ec.europa.eu/eurostat

333 Correspondence with Repatriation Division, Immigration Service Delivery, Department of Justice and Equality, April 2020.

334 Sheridan, A. (November 2019) Annual Report on Migration and Asylum 2018: Ireland, p. 117. Available at: www.emn.ie and www.esri.ie

335 Eurostat, 'Third country nationals who have left the country by type of return and citizenship' [migr_eirt_vol]. Date extracted 11 October 2020. Available at: https://ec.europa.eu/eurostat

336 Correspondence with Repatriation Division, Immigration Service Delivery, Department of Justice and Equality, October 2020.

337 Correspondence with Repatriation Division, Immigration Service Delivery, Department of Justice and Equality, April 2020.

338 Eurostat, 'Third country nationals returned following an order to leave - annual data (rounded)' [migr_eirtn]. Data extracted 2 December 2020. Available at: https://ec.europoa.eu/eurostat. 
development of the Schengen acquis in which Ireland does not participate, Ireland is not bound by the Regulation. However, in accordance with Article 70, Frontex may facilitate operational co-operation with Ireland and the United Kingdom in specific Frontex activities. ${ }^{339}$

A total of 23 people were deported from Ireland as part of this operation. The individuals were of Albanian and Georgian nationality. They were accompanied on the Frontex-chartered flight by two medical staff and two Frontex monitors, as well as officers from the GNIB. ${ }^{340}$

\subsubsection{Amendment to the Immigration Act 1999 in relation to the prohibition on refoulement}

Section 3(1) of the Immigration Act 1999 was amended to confirm that the Minister's power to make a deportation order is subject to the prohibition of refoulement set out in section 3A of the Immigration Act 1999. This section was inserted by section 95 of the Withdrawal of the United Kingdom from the European Union (Consequential Provisions) Act 2019, and provides that a person shall not be expelled or returned in any manner whatsoever to the frontier of a territory where, in the opinion of the Minister, (a) the life or freedom of the person would be threatened for reasons of race, religion, nationality, membership of a particular social group or political opinion, or, (b) there is a serious risk that the person would be subjected to the death penalty, torture or other inhuman or degrading treatment or punishment. ${ }^{341}$ Section 3A of the Immigration Act 1999 was commenced on 15 July 2019 by the Withdrawal of the United Kingdom from the European Union (Consequential Provisions) Act 2019 (Part 14) (Commencement) Order 2019. ${ }^{342}$

In his speech presenting the Withdrawal of the United Kingdom (Consequential Provisions) Bill 2019 to the Dáil in February 2019, the Minister for Justice and Equality noted in relation to this provision:

The amendments in section 88 and 89 of the Bill are for the purposes of correcting a lacuna in the provisions relating to non-refoulement in our law. I should point out that refoulement considerations were in fact being

\footnotetext{
339 This was also the case in previous iterations of the Frontex Regulation, e.g. Article 51 of Regulation 2016/1624. Article $51(2)$ refers to organisation of return operations.

340 Department of Justice and Equality (4 December 2019) 'Enforced removal of 23 people with Deportation Orders', Press Release. Available at: www.justice.ie.

341 Groarke, S. and P. Brazil (2020) National Statuses granted for protection reasons in Ireland, p. 45. Available at: www.emn.ie, https://doi.org/10.26504/rs96.pdf.

342 S.I. No. 346 of 2019
} 
undertaken at all times. This provision provides legal certainty in this area. $^{343}$

\subsubsection{Voluntary return}

There was a total of 255 voluntary return cases in relation to third-country nationals in 2019, 106 of whom were assisted by the International Organization for Migration (IOM) ${ }^{344}$ The top five countries of citizenship for IOM-assisted return in 2019 were South Africa, Georgia, Brazil, USA and Ethiopia. ${ }^{345}$

According to Eurostat data, the top countries of citizenship for total voluntary return were: Brazil/South Africa; Georgia/Pakistan; Albania/Malaysia; and Nigeria/USA.

\begin{tabular}{|l|l|}
\hline Country of citizenship & Number \\
\hline Brazil/South Africa & 40 \\
\hline Georgia/Pakistan & 20 \\
\hline Albania/Malaysia & 15 \\
\hline Nigeria/United States & 10 \\
\hline
\end{tabular}

Source: Eurostat Third-country nationals who have left the territory by type of return and citizenship [migr_eirt_vol]. Data extracted: 31 October 2020

The IOM, funded by the Department of Justice and Equality, offers voluntary assisted return and reintegration programmes for asylum seekers, rejected asylum seekers and other illegally present migrants in vulnerable situations.

Asylum seekers, or asylum seekers who have failed in their claim and who have not had a deportation order made against them, unaccompanied minor children (where return has been deemed to be in their best interests by relevant social work teams) and suspected victims of trafficking (identified within the national referral mechanism identification system), who wish to return home, are assisted with return under the VARRP. Other illegally present migrants are assisted with return under the IVARRP, which is co-funded by the EU on a 75/25 basis.

Under these programmes, all travel arrangements including flights for such

343 Department of Justice and Equality (27 February 2019) 'Withdrawal of the United Kingdom from the European Union (Consequential Provisions) Bill 2019 Second Stage Speech by Charlie Flanagan TD, Minister for Justice and Equality, Dáil Éireann, 27 February 2019'. Available at: www.justice.ie.

344 Correspondence with Repatriation Division, Immigration Service Delivery, Department of Justice and Equality, April 2020.

345 Correspondence with IOM Ireland, November 2020. 
persons are arranged and paid for and, where required, the IOM will assist in securing travel documents, arranging fitness to travel medical assessments and providing medical escorts where required, and will give assistance at the airport at departure, transit and arrival. Persons availing of these programmes can apply for reintegration assistance to allow them to start up a business or enter further education or training when they are back in their country of origin. This takes the form of an 'in-kind' grant rather than a cash payment.

\subsection{CASELAW}

\section{Procedure for assessment of application for residence card by qualifying family member under Citizens' Directive}

In SS v Minister for Justice [2019] IESC 37, the Supreme Court considered the procedure by which the Minister assessed an application for a residence card by a qualifying family member of an EU citizen under the Citizens' Directive. On 30 January 2018 the applicant/appellant sought a residence card, claiming to be a qualifying family member dependent on the alleged spouse of his father, who was an EU citizen. The applicant was a 26-year-old Pakistani national who claimed to be a family member of the Romanian lady whom his father had purported to marry in November 2014. On 20 June 2018 the applicant was arrested in Portlaoise for the purposes of deportation, having been served with a deportation order on 9 January 2018. An application for habeas corpus pursuant to Art. $40.4 .2^{\circ}$ was made on his behalf, claiming that he could not be deported until such time as his application for a residence card under the Citizens' Directive had been determined.

In the High Court, Humphreys J held that the applicant was in lawful custody ([2018] IEHC 442) and dismissed the application. On appeal, the Court of Appeal again held that the applicant was in lawful custody; Kennedy J's judgment centred on s.5 of the Interpretation Act 2005 and the necessity to interpret the Free Movement of Persons Regulations in accordance with Directive 2004/38/EC. Both the High Court and the Court of Appeal thus held that there should be read into the Regulations a requirement that a person applying for a residence card must first establish that he or she is an actual qualifying family member.

The Supreme Court allowed the applicant's appeal against this decision. Charleton $\mathrm{J}$ delivered the judgment of the court, noting that the issue in the appeal was the interpretation of domestic regulations, namely whether the EU (Free Movement of Persons) Regulations 2015 (S.I. No. 548 of 2015) granted the right to a stay pending the resolution of the application. The Supreme Court held that the answer was clearly that the Regulations, in the replication of rights, did what was required by the Directive but also granted that right. Charleton $\mathrm{J}$ accepted that the phrase 'may remain in the State pending a decision on the application' which appeared in the Regulations was not replicated in the Directive. While there was a limit to the 
duty of the national courts, which must interpret national law in light of any European law obligations as far as this is possible, this could not enable a distortion of what the enactment meant. Charleton J was satisfied that the Regulations replicated the entitlement of a person applying for refugee status to remain in the State pending the outcome of that application and the determination of any appeal as in $\mathbf{5 . 9}$ of the Refugee Act 1996. Charleton J also held that what was not made integral to the national legislation was any concept of a two-part test: that of demonstrating on application a prima facie case of entitlement by virtue of being a family member of a European Union national, as defined, followed by proof of dependency and relationship. This approach, which had been urged by the Minister and accepted by the High Court and Court of Appeal, could not be read into the national legislation. The applicant's arrest was thus unlawful and at the date of the application under Art. 40 he was not detained in accordance with law. 



\section{CHAPTER 7}

\section{Integration}

\subsection{INTEGRATION}

\subsubsection{Mid-term review of Migrant Integration Strategy}

The Migrant Integration Strategy - A Blueprint for the Future, which provides the framework for Government action on migrant integration from 2017 to 2020, was published in February 2017.

Integration is defined in current Irish policy as the 'ability to participate to the extent that a person needs and wishes in all of the major components of society without having to relinquish his or her own cultural identity'. The Strategy's key message is that successful integration is the responsibility of Irish society as a whole.

The Strategy covers EEA and non-EEA nationals, including economic migrants, refugees and those with legal status to remain in Ireland. It is directed at Government Departments, public bodies, the business sector, and community, voluntary, faith-based, cultural and sporting organisations as well as at families and individuals. ${ }^{346}$

Action 76 of the Strategy provides that: 'Progress on the implementation of these actions will be reviewed at the end of 2018 and a report prepared for Government.' The Migrant Integration Strategy 2017-2020: Progress Report to Government was published in $2019 .{ }^{347}$

The Progress Report measures the implementation of each of the commitments in the Strategy, using a traffic light system to mark each as on track; minor problems or delays; one or more major difficulties; or complete. According to the Progress Report, there were examples of major achievements at the mid-term stage:

A number of significant milestones, that were included as commitments in the Strategy, have been achieved. These include the enactment of the Education (Admission to Schools) Act 2018; ${ }^{348}$ adoption of Ireland's Second

346 Sheridan, A. (November 2019) Annual Report on Migration and Asylum 2018: Ireland (print version), p. 145. Available at: www.emn.ie and www.esri.ie.

347 Department of Justice and Equality (June 2019) Migrant Integration Strategy 2017-2020: Progress Report to Government Available at: www.justice.ie.

348 The Education (Admission to Schools) Act 2018 is intended to create a more parent-friendly, equitable and consistent approach to how school admissions policies operate for all primary and post-primary schools. This will help to ensure 
National Intercultural Health Strategy; the establishment of the Communities Integration Fund; commencement of an OPMI/ESRI Integration Research Programme; and mapping of data needs for monitoring integration. These are important developments that will support the achievement of the objectives of the Strategy. ${ }^{349}$

The Progress Report also noted that some challenges had been experienced with monitoring progress on actions 'with a process focus and/or are crosscutting'. The importance of integration monitoring data to prioritise implementation of actions was noted. ${ }^{350}$

In his foreword to the Strategy, the Minister of State at the Department of Justice and Equality said that he would like to see further emphasis on combating racism and xenophobia and actions to support integration and social cohesion at the local level during the remainder of the Strategy. ${ }^{351}$ Thematic recommendation of the Progress report included to:

- consider whether additional actions to combat racism and xenophobia may be required in the Strategy;

- develop greater synergy and more active links between Local Authority integration work and the implementation of the National Strategy;

- informed by integration monitoring, develop a programme to advance integration outcomes in adult education (in particular English language acquisition) and employment (access and progression). ${ }^{352}$

Commenting on the publication of the mid-term review, the Immigrant Council of Ireland (ICl) said that it considered the Migrant Integration Strategy to be 'a solid framework, but insufficient political prioritisation and resources threaten its effective implementation'. The $\mathrm{ICl}$ welcomed the focus on the need for greater efforts on racism and the establishment of the Anti-Racism Committee. It also commented that there was a gap in the original strategy in relation to actions in relation to housing, as 'people from a migrant background are over-represented in housing crisis figures'. ${ }^{353}$

that all children, regardless of nationality or religion, are able to access education (Progress Report to Government, p. 7).

349 Department of Justice and Equality (June 2019) Migrant Integration Strategy 2017-2020: Progress Report to Government, p. 10 Available at: www.justice.ie. Ibid. Ibid. p. 3. Ibid. p. 12. Immigrant Council of Ireland (28 June 2019) 'Progress report into Ireland's integration strategy highlights gaps'. Press Release. Available at: www.immigrantcouncil.ie. 


\subsubsection{Labour market integration}

Funding of $€ 4.5 \mathrm{~m}$ from the European Union's Asylum, Migration and Integration Fund (AMIF) was announced in October 2019 over the period 2019-2022 for projects to promote the integration of migrants, including in relation to English language classes and workplace training. Some 19 projects were allocated funding, including both continuing projects from the previous funding period and some new projects. Examples of projects funded include:

- a project in Cork to provide employment-readiness training to migrants based around a horticultural theme;

- a nationwide project to provide structured diversity training in schools to promote diversity and integration

- a nationwide project to provide personal development programmes, through participation in personal, physical, community and team challenges. ${ }^{354}$

Under the AMIF-funded Integration Hub project, in June 2019 the ICI launched its Diversity is good for business leaflet, which includes information on the employment rights of asylum seekers, recognised refugees, recipients of subsidiary protection or leave to remain, victims of trafficking and other vulnerable non-EU/ European Economic Area (EEA) migrant communities in Ireland. ${ }^{355}$

\subsubsection{Community engagement}

As reported in previous years, a Communities Integration Fund was launched by the Minister of State at the Department of Justice and Equality alongside the Migrant Integration Strategy in 2017.

In July 2019, the 124 community projects that received funding under the third year of the fund were announced. A total of $€ 526,000$ was made available, with projects receiving grants of between $€ 1,000$ and $€ 5,000$ in every county throughout Ireland for locally run projects to support the integration of migrants. In 2019, additional funding of $€ 26,000$ was made available by the Office of Public Works on a once-off basis for projects focused on the arts. ${ }^{356}$

\subsubsection{Political participation and civic engagement}

Local elections were held in Ireland in June 2019. In 2018, the ICl had run workshops on voting rights and produced ten videos in different languages,

354 Department of Justice and Equality (7 October 2019) 'Funding for gender equality and migrant integration announced by Minister Flanagan and Minister Stanton', Press Release. Available at: www.justice.ie.

355 Immigrant Council of Ireland (June 2020) Impact Report 2019, p. 27. Available at: www.immigrantcouncil.ie.

356 Department of Justice and Equality (11 July 2019) 'Ministers announce $€ 526,000$ Community Integration Fund 2019', Press Release. Available at: www.justice.ie. 
\#GoVote!, to encourage migrants to vote in the local elections. ${ }^{357}$ An internship scheme where five migrants interned with councillors also took place during 2018, with a progress report published in 2019. The videos were re-run just before the elections in 2019. The ICl noted in its 2019 Impact Report that just nine councillors with a migrant background were elected out of a total of 949 councillors across Ireland, and emphasised its ongoing work encouraging migrant political participation, which included 17 political participation training workshops across Ireland, reaching 242 people. ${ }^{358}$

\subsubsection{Engagement of diaspora communities}

In April 2019, the Minister for Justice and Equality hosted a public consultation in relation to the International Decade for People of African descent. ${ }^{359}$ Approximately 100 stakeholders were in attendance, including representatives of African community organisations. The purpose of the consultation was to involve stakeholders in the design of a programme in Ireland to mark the International Decade for People of African Descent. ${ }^{360}$

In his address to the UN Convention on the Elimination of all Forms of Racial Discrimination (CERD) Committee, the Minister of State at the Department of Justice and Equality said that, at the consultation: 'We spoke about how best to leverage the opportunities represented by the Decade to celebrate the contribution of People of African Descent to Ireland's society and economy and to address the problems of discrimination and exclusion they still face.'

He noted that a Steering Committee of African Descent stakeholder organisations has been established and grant funding has been provided to support the development of a programme of action. ${ }^{361}$ The UN CERD Committee recommended further efforts in this regard in its Concluding Observations on Ireland in December 2019 (see also Section 2.3.1).

\section{Africa Day 2019}

As in other years, Africa Day was celebrated in 2019 on 25 May. The 2019 programme of events focused on community involvement and engagement. A

357 Sheridan, A. Annual Report on Migration and Asylum 2018: Ireland (print version), pp. 152-153. Available at: www.emn.ie and www.esri.ie.

358 Immigrant Council of Ireland (June 2020) Impact Report 2019, pp. 21 and 29. Available at: www.immigrantcouncil.ie.

359 The Decade is a UN initiative that grew from the Durban Declaration and Programme of Action from the 2001 World Conference Against Racism. The Decade, which was the subject of a 2013 UN resolution, runs from 2015 to 2024. Its three interdependent themes are Recognition, Justice and Development. States are called upon to mark the Decade through adoption of a Programme of Action based on these themes. Source: www.justice.ie. Department of Justice and Equality (3 April 2019) 'Minister Stanton hosts Public and Stakeholder Consultation for the International Decade for People of African Descent (2015-2024)', Press Release. Available at: www.justice.ie.

361 Department of Justice and Equality (2 December 2019) 'Minister Stanton delivers Ireland's National Statement to CERD in Geneva', Press Release. Available at: www.justice.ie. 
programme of events was developed nationwide in partnership with ten local authorities in Cork, Dublin, Galway, Kildare, Laois, Limerick, Meath, Waterford and Wexford. ${ }^{362}$

\subsubsection{Non-discrimination}

\section{Anti-racism}

In June 2019, to coincide with the publication of the Migrant Integration Strategy: Progress Report to Government, the Minister of State at the Department of Justice and Equality announced that an anti-racism committee would be established later in 2019.

According to the Minister, the committee's work would cover two strands:

1. a public sector strand to allow for more in-depth discussions of what needs to be done by public sector organisations and how it can be done;

2. an expert strand that will consider how to develop a clear understanding of racism, where it occurs, and what can be done to combat it, drawing on international experience. ${ }^{363}$

The Minister subsequently announced the establishment of the Committee during his address to Ireland's examination by the UN Committee on the Convention on the Elimination of Racial Discrimination (CERD) in December 2019. ${ }^{364}$ Professor Caroline Fennell of University College Cork and a commissioner of the Irish Human Rights and Equality Commission (IHREC) will chair the Committee. Its membership will include both State and non-State actors. The committee was to be convened in early 2020 and report to Government within three months. ${ }^{365}$

The $\mathrm{ICl}$ again ran the Transport Against Racism campaign in co-operation with Transport for Ireland in 2019. The 2019 campaign collected selfies from commuters which were used in a collage image on public transport. Over 1,000 selfies were collected. In addition, under the training heading of the Integration Hub project, the $\mathrm{ICI}$ ran 32 anti-racism and diversity workshops, reaching 457 people. ${ }^{366}$ Department of Justice and Equality (28 June 2019) 'Minister Stanton announces new Anti-Racism Committee', Press Release. Available at: www.justice.ie. 
The ICl also provides a Racist Incident Support and Referral Service. During 2019, ICl provided such support to 46 people ${ }^{367}$ (25 in 2018). ${ }^{368}$ The Irish Network Against Racism (INAR) in its 2019 report on reporting of racist incidents noted a total of 530 reports of racism in the year, including discrimination, racist assaults and the growth of hate speech. ${ }^{369}$

\section{Consultation on hate speech}

The Department of Justice and Equality launched a consultation on hate speech in October 2019. This was part of the review of existing law in this area, the Prohibition of Incitement to Hatred Act 1989. According to the Department of Justice and Equality:

Improvements in our hate-speech legislation are one element in a wider suite of measures across all areas of Government which are designed to address hatred and intolerance, including the development of hate crime legislation. ${ }^{370}$

The consultation gave the option of respondents filling out a survey, making written submissions or participating in workshops. The first of the workshops took place on 24 November 2019.371 This methodology was a new approach to consultations. The Secretary General of the Department of Justice and Equality noted that within 24 hours of the launch, around 2,000 submissions had been received. ${ }^{372}$

\section{Garda Síochána Diversity and Integration Strategy 2019-2021}

An Garda Síochána published its Diversity and Integration Strategy 2019-2021 in October 2019. The Strategy is structured around five priorities:

- Protecting the Community - Protect the safety, wellbeing and rights of all, particularly minority and marginalised communities and vulnerable individuals.

- Data - Ensure the most effective and accurate management of data on hate crime in a safe, secure and legal manner, whilst respecting the privacy and rights of all persons.

\section{Ibid., p. 32.}

Sheridan, A. (November 2019) Annual Report on Migration and Asylum: 2018, p. 151. Available at: www.emn.ie and www.esri.ie.

369 Irish Network Against Racism (18 March 2020) 'Racism figures climb in the context of political hate speech', Media Release. Available at: www.inar.ie.

370 Department of Justice and Equality (10 October 2019) 'Hate Speech Public Consultation'. Available at: www.justice.ie

371 Department of Justice and Equality (2 December 2019) 'Minister Stanton delivers Ireland's National Statement to CERD in Geneva', Press Release. Available at: www.justice.ie.

372 Department of Justice and Equality (8 November 2019) Speech by Secretary General Aidan O'Driscoll at the Justice Committee regarding The Department of Justice and Equality's Transformation programme. Available at: www.justice.ie. 
- Our People - Develop the skills and environment needed to ensure equality, diversity, integration and human rights in all aspects of operational policing.

- Partnership - Engage with internal and external stakeholders in a proactive and inclusive manner to build trust and identify the policing needs of all diverse, minority and 'hard to reach' communities.

- Communication - Communicate openly, honestly, sensitively and respectfully with all our communities, colleagues and partners to improve trust and confidence in the policing service we deliver to all people. ${ }^{373}$

The Strategy also included the development by An Garda Síochána of a working definition of hate crime and a non-crime hate incident. A significant focus of the Strategy is 'enhancing the identification, reporting, investigation and prosecution elements of hate crime'. ${ }^{374}$ The Strategy acknowledges that there is currently an underreporting of crimes against minority groups. According to the Garda Commissioner:

An Garda Siochána is further pleased to deliver a working hate crime definition, which recognises the existing and emerging diverse composition of our communities, and aims to protect all minorities and diverse groups in society. This strategy will facilitate enhanced reporting, recording, investigating and prosecuting mechanisms in respect of hate crime and the introduction of a Pulse ${ }^{375}$ record for non-crime hate incidents. ${ }^{376}$

In his address to the UN CERD Committee, the Minister of State at the Department of Justice and Equality noted that An Garda Síochána had recently decided to update its policy on uniform in order to encourage candidates from minority communities by taking account of religious and ethnic requirements, subject to operational and health and safety obligations. The wearing of the turban for members of the Sikh community and the hijab for members of the Muslim community is being allowed. ${ }^{377}$ The CERD Committee recommended full implementation of the Strategy in its Concluding Observations on Ireland in December 2019 (see also Section 2.3.1).

\subsubsection{Research}

The Economic and Social Research Institute (ESRI) published Data for Monitoring

\footnotetext{
373 An Garda Síochána (October 2019) An Garda Síochána Diversity and Integration Strategy 2019-2021, pp. 7-11. Available at: www.garda.ie.

Ibid., p. 5.

Pulse - national police database.

An Garda Síochána (October 2019) An Garda Síochána Diversity and Integration Strategy 2019-2021, p. 3. Available at: www.garda.ie.

377 Department of Justice and Equality (2 December 2019) 'Minister Stanton delivers Ireland's National Statement to CERD in Geneva', Press Release. Available at: www.justice.ie.
} 
Integration: Gaps, Challenges and Opportunities ${ }^{378}$ on 14 March 2019. This research was funded as part of the Office for the Promotion of Migrant Integration (OPMI)/ESRI research programme under the Department of Justice and Equality Migrant Integration Strategy for 2017-2020.

The report maps the availability of quantitative data on immigrant integration in Ireland. It looks at data collected by the Central Statistics Office (CSO) through large-scale surveys such as the Labour Force Survey (LFS), the Survey on Income and Living Conditions (SILC) and the Census; administrative immigration data collected by the Department of Justice and Equality; and data held across other Government Departments on 'mainstreamed integration.' Ireland does not have a population or migrant register, so the study found that 'survey data are critical to estimating the size of the non-Irish population'. The report also pointed to some significant gaps in relation to administrative immigration data collected. These include issues with data quality and reliability and timing of reporting in relation to residence permit data, which are collected by the Garda National Immigration Bureau (GNIB) and passed on to the DJE. The DJE is undertaking various initiatives to address these issues, including via the Data and Research Strategy 2018-2020. The study also highlighted significant data gaps in this area, including no residence permit data collected on non-EEA migrants under 16 and no data on family reunification for economic migrants. The study also highlighted possibilities to harness potential from or improve data collection in existing administrative data sources in relation to 'mainstreamed integration'; for example, social welfare, health and education data. ${ }^{379}$

Also, part of the OPMI/ESRI research programme Diverse Neighbourhoods: an analysis of the residential distribution of immigrants in Ireland ${ }^{380}$ was published on 26 June 2019. This research found that, relative to the Irish population, migrants are relatively evenly distributed across Ireland. Migrants are more likely to live in urban areas, with over half in Dublin, Cork and Limerick, and in private rented accommodation. Non-EU migrants tend to live in areas of higher unemployment and those with lower levels of English tend to live in areas with fewer third-level graduates. The study used 2011 and 2016 Census data and found that residential segregation remained relatively stable over the period. ${ }^{381}$

EMN Ireland and the ESRI published Policy and practice targeting the labour market integration on non-EU nationals in Ireland on 19 June 2019. This study was

\footnotetext{
378 Fahey, E., F. McGinnity and E. Quinn (March 2019) Data for Monitoring Integration: Gaps, Challenges and Opportunities, Economic and Social Research Institute Available at: www.esri.ie.

379 Ibid, pp. i-iv.

380 Fahey, E., H. Russell, F. McGinnity and R. Grotti (June 2019) Diverse neighbourhoods: an analysis of the residential distribution of immigrants in Ireland Economic and Social Research Institute. Available at: www.esri.ie.

381 Economic and Social Research Institute (26 June 2019) 'Generally low levels of residential segregation of migrants in Ireland', Press Release. Available at: www.esri.ie.
} 
originally undertaken as the Irish contribution to the EU-wide EMN study Labour market integration of third-country nationals in EU Member States. This study examined broader labour market policy governing access of non-EEA nationals to the labour market in Ireland and the employment permits system, and policies and measures to improve labour market access for non-EEA nationals living in Ireland. The scope of the study was limited to regularly staying non-EEA nationals with a right to work. It examined relevant actions from the Migrant Integration Strategy and examples from the public, private and community sectors.

EMN Ireland and the ESRI hosted Migrant Integration: policy and place on 26 June 2019, at which the Minister of State at the Department of Justice and Equality launched the two reports Diverse neighbourhoods and Policy and practice targeting the labour market integration on non-EU nationals in Ireland. Commenting in relation to the Diverse neighbourhoods research, the Minister said that the Department of Justice and Equality was working in co-operation with the Department of Rural and Community Development and local authorities, in the framework of the Migrant Integration Strategy, to develop targeted approaches where necessary, and that: 'Research evidence like this will support this work and is therefore of great benefit to both central and local policymakers.' ${ }^{382}$

\subsection{CITIZENSHIP, NATURALISATION AND STATELESSNESS}

\subsubsection{Citizenship statistics}

Three citizenship ceremonies were held in 2019: on 29 April and 2 December in Killarney, and on 28 June in Waterford. Some 2,347 and 1,922 certificates of naturalisation were conferred at the two Killarney ceremonies respectively, while a total of 634 persons received certificates at the Waterford ceremony. ${ }^{383}$ These figures include both EU and non-EU nationals.

British nationals continued to make applications for Irish citizenship in the wake of the Brexit referendum and were the second highest nationality represented at the three ceremonies -293 certificates were conferred on people of UK nationality on 29 April, 252 on 9 December and 106 on 28 June. ${ }^{384}$

\subsubsection{Legal challenge to concept of 'continuous residence' in relation to eligibility for naturalisation}

Under the Irish Nationality and Citizenship Act 1956 (as amended), in order to apply for naturalisation, an applicant must have a total 'reckonable residence' of five

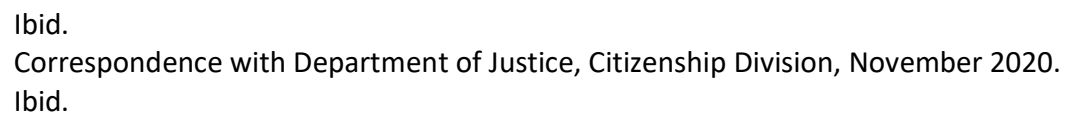


years during the previous nine years, including one year of continuous residence prior to the application. A 'six-week rule' operates on an administrative basis, in order to provide for short-term and temporary absences from the State.

In July 2019 the discretionary six-week rule was found by the High Court to be unlawful. Barrett J held in Jones $v$ Minister for Justice and Equality that 'continuous residence', as set down in the Irish Nationality and Citizenship Act 1956 means unbroken and uninterrupted residence, thus no absence is legally allowed. ${ }^{385}$ Following the judgment, the Department of Justice and Equality stated that the Minister of Justice and Equality had received approval from Government for a proposed Bill to address the issues raised in the judgment. The Department stated that the Bill would be put before the Houses of the Oireachtas for consideration by mid-September 2019. ${ }^{386}$

The judgment was subsequently appealed by the applicant and was heard at the Court of Appeal on 8 October 2019. On 14 November 2019, the Court of Appeal delivered its judgment in which it held that the High Court erred in law in stating that naturalisation applicants must have unbroken residence in the year prior to their application, which the Court of Appeal stated was 'unworkable, overly literal, unduly rigid and gives rise to an absurdity'. ${ }^{387}$ The Court of Appeal stated that continuous residence does not require uninterrupted presence in the State nor impose a complete prohibition on travel outside of the State. The Court of Appeal also held that the Minister's policy of permitting up to six weeks' absence from the State was not rigid or inflexible as put forward by the applicant, and stated that the six-week rule was reasonable and pragmatic and 'facilitates flexibility, clarity and certainty' in establishing how the 'continuous residence' requirement must be satisfied by naturalisation applicants. ${ }^{388}$ See Section 7.2 .5 for detailed case summaries.

\subsubsection{Irish Nationality and Citizenship (Restoration of Birthright Citizenship) Bill 2017}

A Private Members' Bill - the Irish Nationality and Citizenship (Restoration of Birthright Citizenship) Bill $2017^{389}$ was heard at second stage in Dáil Éireann in January 2019. This Bill was originally introduced in the Oireachtas by Deputies Ruth Coppinger, Paul Murphy and Mick Barry on 9 March 2017.

385 [2019] IEHC 519.

386 INIS, 'Updates and announcements 2019: Updated Statement from INIS on the recent judgment in the High Court citizenship case', 29 July 2019. Available at: http://inis.gov.ie/en/INIS/Pages/2019.

387 Roderick Jones v Minister for Justice and Equality [2019] IECA 285.

388 Ibid.

389 Irish Nationality and Citizenship (Restoration of Birthright Citizenship) Bill 2017 (No. 36 of 2017). Available at: www.oireachtas.ie. 
The Bill proposed to provide for an automatic entitlement to citizenship for all persons born on the island of Ireland. It proposed to reinstate the situation prior to the Constitutional Referendum on citizenship in 2004 and the consequent amendments to the Irish Nationality and Citizenship Act 1956, which introduced conditions for the naturalisation of children born to non-Irish parents in Ireland. Section 6A of the Irish Nationality and Citizenship Act, which was inserted in 2004, provides that:

A person born in the island of Ireland shall not be entitled to be an Irish citizen unless a parent of that person has, during the period of 4 years immediately preceding the person's birth, been resident in the island of Ireland for a period of not less than 3 years or periods the aggregate of which is not less than 3 years.

The Deputies introducing the proposals to repeal the legislation argued that this legislation led to discrimination between children born of Irish and non-Irish parents and pointed to high-profile cases where children born of non-EEA national parents had been subject to deportation orders. They set the Bill in the context of the numbers of undocumented children in Ireland, pointing to the Migrant Rights Centre of Ireland (MRCI) research estimating that there are between 2,000 and 5,000 undocumented children in the State, and the absence of a regularisation scheme. ${ }^{390,391}$

The Minister for Justice and Equality opposed the Bill. The Minister argued that the provisions of the Bill would make Ireland the only one of the $28 \mathrm{EU}$ Member States to introduce automatic and unconditional citizenship to children born in Ireland, with consequences for relationships with other EU Member States and the UK. He also pointed out that automatic citizenship entitlements give rise to citizenship entitlements for a broader range of family members. The discretion introduced by the 2004 Act was intended to provide a check on any potential abuse of citizenship entitlements.

He also pointed to the legal pathways in existence for naturalisation, whereby: 'just over 27,000 children, the vast majority of whom were born to non-EEA nationals, have become citizens of Ireland through naturalisation. ${ }^{392}$

The Minister also expressed concerns about the implications of the proposal in relation to Northern Ireland. The Bill could give rise to an incentive whereby

390 Irish Nationality and Citizenship (Restoration of Birthright Citizenship) Bill 2017: Second Stage [Private Members], Deputy Paul Murphy. Available at: www.oireachtas.ie.

391 See also Migrant Rights Centre of Ireland (3 July 2019) 'New survey gives unprecedented picture of undocumented children and young people in Ireland', Press Release. Available at: www.mrci.ie.

392 Department of Justice and Equality (17 January 2019) Speech by Minister for Justice and Equality, Charlie Flanagan TD, Irish Nationality and Citizenship (Restoration of Birthright Citizenship) Bill 2017. Available at: www.justice.ie. 
persons could travel from the UK to Northern Ireland to obtain Irish citizenship, without ever having entered the territory of the State. The Minister considered that this could have serious implications in a Brexit scenario. ${ }^{393}$

The Bill was defeated by 82 votes to 43 (two abstentions) on 24 January 2019..394

\subsubsection{Statelessness}

Ireland has ratified the 1954 Convention on the status of stateless persons and the 1961 Convention on the Reduction of Statelessness. ${ }^{395}$ Ireland does not have a dedicated statelessness determination procedure. The CERD, in its Concluding Observations on the fifth periodic report of Ireland, recommended that Ireland introduce a dedicated statelessness determination procedure (see also Section 2.3.1 for full discussion of Ireland's examination by the UN CERD Committee in December 2019). ${ }^{396}$

\subsubsection{Caselaw 397}

\section{Continuous residence for the purpose of naturalisation: Jones $v$ Minister for Justice and Equality [2019] IEHC 519 and [2019] IECA 285}

The decision of the High Court in Jones v Minister for Justice [2019] IEHC 519 considered the correct interpretation of the requirement of 'continuous residence' for the purpose of an application for naturalisation. Section 15(1) of the Irish Nationality and Citizenship Act 1956, as amended, provides, inter alia, that 'Upon receipt of an application for a certificate of naturalisation, the Minister may, in his absolute discretion, grant the application, if satisfied that the applicant ... (c) has had a period of one year's continuous residence in the State immediately before the date of the application.' The applicant was an Australian citizen who applied to become a naturalised Irish citizen. The Minister refused his application for naturalisation on the basis that he had not been continuously resident in the State in the year immediately before he applied for naturalisation. The Minister operated a policy which permitted a maximum of six weeks' absence from the State, with the possibility of longer periods being permitted in exceptional or unavoidable circumstances. However, during the year immediately prior to his application, the applicant was out of Ireland for 100 days: 97 on holiday, three for work reasons. He challenged the refusal of his application, arguing inter alia that the Minister had erred in law in failing to make reasonable allowance for

Ibid.

See https://www.oireachtas.ie/en/debates/debate/dail/2019-01-24/21/.

Ireland acceded to the 1954 Convention on the rights of stateless persons on 17 December 1962 and the 1961 Convention on the Reduction of Statelessness on 18 January 1973.

396 CERD (12 December 2019) Concluding Observations on the combined fifth to ninth reports of Ireland, Advanced Unedited Version, CERD C/IRL/CO/5-9, paragraph 36, section d. Available at: https://tbinternet.ohchr.org.

397 Case analysis by EMN legal consultant. 
temporary absences from the State.

Barrett $J$ in the High Court held that the Minister, when assessing whether an applicant had a period of one year's continuous residence, was not acting in the realm of discretion - either an applicant had had a period of one year's continuous residence or he did not. The court held that although the Minister had manifested 'very real humanity' in trying to nuance the clear wording and effect of s.15(1)(c), by applying a discretionary absence period of six weeks and possibly more in exceptional or unavoidable circumstances, the Minister had gone beyond what was legally permissible in this regard, because the 1956 Act did not confer any discretionary power on the Minister in this regard. Barrett $\mathrm{J}$ held that the word 'continuous' in s.15(1)(c) bears its ordinary English-language meaning, being, per The Concise Oxford Dictionary of Current English (12th ed., 2011), 'unbroken, uninterrupted, connected throughout in space or time'. The effect of this definition when applied to s.15(1)(c) was held to require that for the last year prior to a naturalisation application an applicant must show a one-year period of residence in Ireland that is 'unbroken, uninterrupted, connected throughout in space or time'. Barrett J rejected the argument that this interpretation would result in an absurdity that would bring s.5(1)(b) of the Interpretation Act 2005 into play. Noting that there was no evidence before the court as to why the one year period was included by the Oireachtas in the 1956 Act, Barrett J stated that it was not difficult to imagine reasons why such an obligation might have made sense to lawmakers, e.g., it may have been to ensure that citizens-to-be enjoy a concrete connection with the State, or to ensure that citizens-to-be were attuned to the way of life in Ireland at the time of naturalisation, or for some other reason. Accordingly, Barrett $\mathrm{J}$ held that while the Minister was not entitled in law to adopt a six-week discretionary period regarding absences from the State, the Minister was on the facts of this case correct to refuse the application for naturalisation because the applicant had not been continuously resident in the State in the year immediately prior to his application. Barrett $J$ accepted that this interpretation could cause difficulties in a world where many people travel abroad for work or holiday more regularly than in times past, but held that the resolution of these difficulties was not a matter for the courts but rather for the legislature.

The Minister was subsequently granted an accelerated appeal hearing to the Court of Appeal. In Jones v Minister for Justice [2019] IECA 285, the Court of Appeal held that Barrett J had erred in his construction of the term 'continuous residence' in s.15(1)(b) of the 1956 Act, and allowed the Minister's appeal. Whelan J delivered the judgment of the court, holding that as a matter of statutory interpretation, the term 'continuous residence' should be given its ordinary and natural meaning unless to do so would result in an absurdity. It was held that the construction of s.15(1)(b) of the 1956 Act adopted by the High Court judge was unworkable and gave rise to an absurdity, and that continuous residence within the meaning of the 
sub-section did not require uninterrupted presence in the State throughout the entirety of the relevant year.

Whelan J held that the term 'continuous residence' is wholly distinct and separate from the concepts of 'ordinary residence' or 'residence' per se, and that it was clear that the Oireachtas had mandated that a more rigorous approach be applied to the physical presence of an applicant in the State in the year immediately prior to the application being submitted. It was held that by including the 'continuous residence' requirement in the year immediately preceding the application, the Oireachtas had attached significant importance to physical presence within the State during the relevant year, and that 'an applicant must generally be physically present in the State during the particular year and an application may be refused if there are significant absences'. Having regard to the overall scheme of the legislation and the tenor of the Minister's policy, which permitted up to six weeks' absence from the State, Whelan J was satisfied that this was a reasonable policy aimed at ameliorating the potential harshness and rigidity of the first part of s.15(1)(c), which placed 'a significant but by no means absolute premium on the continuity of physical presence in the State during the relevant year'.

Whelan $\mathrm{J}$ also rejected the argument that the adoption of this policy amounted to an unlawful fettering of discretion or acted as the imposition of an extra-statutory barrier to naturalisation. Accordingly, it was held that the High Court had erred in respect of the findings in relation to the six-week policy and the appeal was dismissed.

\section{Disclosure of reasons for naturalisation decision: AP v Minister for Justice [2019] IESC 47}

The applicant was an Iranian national who arrived in the State in October 1989 and was granted refugee status in December 2001. He had made four previous applications for a certificate of naturalisation under the provisions of the Irish Nationality and Citizenship Act 1956 (as amended). His fifth application for naturalisation was refused by the Minister by decision of 1 September 2014. The submission prepared for the Minister recommended that the application be refused on the basis that the Minister could not have confidence in the appellant's declaration of fidelity and loyalty or undertaking to faithfully observe the laws of the State and could not be satisfied that the appellant met the condition of good character. This recommendation was based on a report that was not disclosed on the basis that ' $[t]$ he State's interest in protecting its security in international relations must in this case outweigh the applicant's interest in knowing the Minister's specific basis for refusing him this privilege'. The applicant challenged this decision, arguing that the Minister was obliged to at least give him the gist of the information that formed the basis for the refusal. 
The High Court (Stewart J) ([2016] IEHC 408) refused the reliefs sought and held that the interests of national security constituted a legitimate justification for the decision of the Minister not to issue reasons for her decision. The Court of Appeal (Peart, Hogan and Gilligan JJ) ([2018] IECA 112) upheld the decision of the High Court.

By determination dated 25 September 2018 ([2018] IESCDET 131), the Supreme Court granted leave to the appellant to appeal the decision of the Court of Appeal.

The Supreme Court held that there is a duty on public law decision-makers to justify a decision not to disclose detailed reasons, following Mallak $v$ Minister for Justice [2012] 3 I.R. 29; [2013] 1 I.L.R.M. 73. The primary objective should be to seek the maximum disclosure that was possible, and to ensure that, in so far as possible, any restriction on disclosure of reasons was demonstrably the least that was necessary. The Supreme Court was satisfied that it was at least possible to put in place an enhanced process whereby an independent assessment could be made as to whether any version of privileged information relied on in refusing an application for naturalisation could be provided in a way that would not affect State interests to the extent that disclosure should not be required at all.

The appeal was allowed.

\section{Challenge to procedure for revocation of naturalisation}

In Damache v Minister for Justice [2019] IEHC 444 the applicant was an Algerian national who had been granted a certificate of naturalisation but subsequently pleaded guilty in the United States to a charge of materially assisting in an Islamist terrorist conspiracy. The Minister subsequently issued a proposal to revoke the applicant's naturalisation on the basis that he had failed in his duty of loyalty and fidelity to the State. The applicant instituted judicial review proceedings challenging the procedure by which revocation of naturalisation is determined under the Irish Nationality and Citizenship Act 1956. The applicant complained inter alia that that the fact that the Minister initiated the revocation process, appointed the committee charged with conducting the inquiry and then reached the final decision was in breach of the constitutional right to fair procedures.

Humphreys J rejected this complaint, holding that revocation is an executive decision made after an advisory inquiry before independent persons using fair procedures. The fact that members of the committee were appointed by the Minister did not mean that they were not independent. It was held that revocation of naturalisation was not a judicial function, and therefore no right of appeal or a right of final approval was reserved to the courts. Humphreys J held that it would be a breach of the separation of powers to so demand. 
Humphreys J also rejected the applicant's complaint of bias as not being founded on any evidence, and also rejected as 'legally unsound' the challenge to the constitutionality of s.19 of the 1956 Act. Similarly, Humphreys J rejected the submission that s.19 of the 1956 Act was incompatible with arts 6 and 13 of the European Convention on Human Rights (ECHR), noting that art. 6 does not apply to public law and that art. 13 applies only in a derivative sense where another Convention right was engaged, but in any event was satisfied that judicial review was an effective remedy for the purposes of that article.

Humphreys J also rejected the applicant's complaint that the revocation procedure was in breach of the Charter of Fundamental Rights. Finally, the court was of the view that the challenge was premature in circumstances where the inquiry had not yet taken place. For all the foregoing reasons, the applicant's challenge was dismissed. Judgment in the Supreme Court appeal to this case was delivered on 14 October 2020. ${ }^{398}$

\section{Refusal of naturalisation on good character grounds: AA v Minister for Justice [2019] IECA 272}

The applicant was a Sudanese national who unsuccessfully applied for asylum in the State but was subsequently granted permission to reside in the State on the basis of marriage. The applicant had two children with her husband, both of whom were Irish citizens, and subsequently applied for naturalisation. The application was refused by the Minister on the basis that the applicant lacked credibility and was therefore not of good character; this finding was based partly on the fact that the applicant had claimed asylum on the basis of a fear of persecution in Sudan, which application had been refused, and also that she had subsequently returned to Sudan. Reference was also made to the circumstances surrounding the fact that the applicant had applied to the Sudanese authorities for a passport.

In the High Court, O'Regan J dismissed the application for judicial review ( $A A v$ Minister for Justice [2016] IEHC 466]), holding that the applicant had not made out a case that the Minister had acted in an arbitrary, capricious or autocratic manner. O'Regan J also held that the Minister was not obliged in the naturalisation process to give advance notice to an applicant of an adverse consideration of which the applicant is already aware, such as the refusal of her asylum application. The applicant appealed against that decision.

The Court of Appeal rejected the applicant's complaint that inadequate reasons were given for the refusal of her application, and also rejected the contention that the Minister should have notified her in advance of the matters going to good 
character on which the Minister intended to rely.

However, the Court of Appeal upheld the applicant's complaint that the Minister was not entitled to place reliance on the fact that her asylum application had been refused in circumstances where her appeal against the refusal of refugee status was ultimately withdrawn because she had been granted permission to reside in the State on the basis of her marriage. Insofar as the Minister relied on the fact that the applicant had travelled back to Sudan less than a year after she withdrew her refugee appeal, Baker J noted that the Minister did not have the asylum file before her and there was nothing on the documents before her that showed the basis on which asylum was sought or why it was refused. In those circumstances, it was held that the Minister's decision was flawed on grounds of reasonableness and the appeal was therefore allowed.

\section{Mihaela lurescu (A Minor) v Minister for Justice and Equality [2019] IEHC 535}

The applicant was a child whose father submitted an application for naturalisation on her behalf under section 15 of the Irish Nationality and Citizenship Act 1956. The Minister refused the application on the basis that the applicant's father did not satisfy the 'good character' requirement because he had a number of convictions. The applicant's mother challenged the decision to refuse her daughter's naturalisation application. The Minister argued that as a child cannot submit an application for naturalisation on their own behalf, but can do so only through a parent or guardian, the statutory conditions for naturalisation had to be met by the parent or guardian as they were the 'applicant' for the purposes of section 15 of the 1956 Act. The High Court (Keane J) rejected this submission and held that on a purposive approach to section 15 of the $1956 \mathrm{Act}$, the child is the person who must satisfy the statutory conditions for naturalisation, not the parent who submits the application on behalf of the child. Accordingly, the High Court quashed the Minister's decision. 



\section{CHAPTER 8}

\section{Trafficking}

\subsection{STATISTICS}

As reported in previous years, the Department of Justice and Equality realigned the reporting of trafficking statistics beginning in 2017. Statistics from 2017 no longer include victims of crimes prosecuted under section 3(2) of the Child Trafficking and Pornography Act 1998, as amended by the Criminal Law (Human Trafficking) Act $2008 .^{399}$

A total of 42 suspected victims of human trafficking were identified by An Garda Síochána during 2019. This compares with some 64 suspected victims identified by An Garda Síochána during 2018. These figures include EU nationals. Victims from Nigeria were the largest discernible group. The majority of the victims (34) were in relation to sexual exploitation.

\section{TABLE 8.1 SUSPECTED VICTIMS OF TRAFFICKING IDENTIFIED IN 2019}

\begin{tabular}{l|l}
\hline $\begin{array}{l}\text { Gender } \\
\begin{array}{l}\text { Regions of } \\
\text { origin }\end{array}\end{array}$ & $\begin{array}{l}17 \text { were from Nigeria. The remainder came from countries including Romania, Albania, } \\
\text { Kenya, Vietnam, DR Congo, Sierra Leone and Zimbabwe. }\end{array}$ \\
\hline $\begin{array}{l}\text { Type of } \\
\text { exploitation }\end{array}$ & $\begin{array}{l}34 \text { were victims of sexual exploitation; three of labour exploitation and five of both } \\
\text { sexual and labour exploitation or forced criminality. }\end{array}$ \\
\hline Source: Department of Justice and Equality, May 2020 and EMN Statistical Annex 2019 (forthcoming).
\end{tabular}

Eight persons were arrested or otherwise involved in criminal proceedings in 2019. As in 2018, there were no trafficking convictions in 2019. ${ }^{400}$ According to the Trafficking in Persons report, the Garda Síochána anti-trafficking unit reported 39 investigations in 2019 (36 for sex trafficking and three for labour trafficking, including two for forced criminality), which included several ongoing investigations that began in prior reporting periods. The government initiated prosecutions for five suspects: two for sex trafficking and three for forced labour. ${ }^{401}$

399 For further detail, see Sheridan, A. (2018) Annual Report on Migration and Asylum 2018: Ireland, p. 159. Available at: www.emn.ie and www.esri.ie.

400 Correspondence with Department of Justice and Equality, May 2020 and EMN Statistical Annex 2019 (forthcoming).

401 US State Department (2020) Trafficking in Persons Report, 20th edition, p. 270. Available at: https://state.gov. 


\subsection{TRAFFICKING IN PERSONS REPORT}

Ireland dropped to Tier 2 Watchlist status for the first time in the United States State Department's Trafficking in Persons report, 20th edition (TIP report), which covers developments for $2019 .{ }^{402}$ Ireland had maintained Tier 2 status for the two previous years and had held Tier 1 status between 2011 and 2016. The TIP report measures the efforts of states to eliminate human trafficking against the minimum standards set in the US Trafficking Victims Protection Act. According to the Tier 2 Watch List rating:

The Government of Ireland does not fully meet the minimum standards for the elimination of trafficking but is making significant efforts to do so. These efforts included increasing prosecutions and funding to NGOs for victim assistance. The government also increased the number of police and immigration officers that received anti-trafficking training and reorganized its antitrafficking coordination unit. However, the government did not demonstrate overall increasing efforts compared to the previous reporting period. ${ }^{403}$

The report continued to highlight that Ireland had not had a trafficking conviction since the law was amended in 2013, and again referred to 'systematic deficiencies in victim identification, referral, and assistance' ${ }^{404}$

As in previous years, the report referred to the concerns of commentators, expressed for example in the report of the GRETA Committee from 2017, regarding the victim identification mechanism and referral to services, including that 'the formal identification scheme excluded EEA-nationals, including Irish nationals, and asylum-seekers with pending applications', with consequent implications regarding access to services. The report noted that 26 of the 42 victims formally identified in 2019 were referred to legal aid services; however, 'they did not report what services other victims received or how many were found ineligible to receive services due to Habitual Residency Condition restrictions' ${ }^{405}$ The report also noted concerns about the need for dedicated shelters for victims of trafficking.

According to the report, in 2019, the 'Labour Relations Court'406 awarded $€ 137,000$ in compensation to eight trafficking victims for lost wages. However, it noted difficulties with victims receiving payment and difficulties with the availability of

402 The scope of the 20th edition is 1 April 2019 to 31 March 2020.

403 Ibid., p. 269.

404 Ibid., p. 270.

405 US State Department (2020) Trafficking in Persons report, 20th edition, p. 271. Available at: https://state.gov.

406 This is a direct quote from the TIP report. There is no such entity in Ireland. The Workplace Relations Commission (WRC) adjudicated on several cases regarding payment of wages and other employment rights issues regarding nonEEA national fishermen during 2019. Determinations of the WRC and the Labour Court are available on a joint determinations database available via https://www.workplacerelations.ie/en/search/?decisions. 
avenues for compensation for trafficking victims. According to the report: 'Victims of sex trafficking had no verifiable expenses or employment losses, and the LRC was unavailable to undocumented workers, who could only pursue civil suits if they could prove they took all reasonable steps to rectify their irregular working status. ${ }^{407}$

While the TIP report said that the Irish Government had decreased law enforcement and victim protection efforts in the reporting period, it found that prevention efforts had been maintained. This included interagency co-operation, awareness-raising campaigns and funding for research and awareness-raising in relation to the criminalisation of the purchase of sex. ${ }^{408}$

The Immigrant Council of Ireland (ICI) agreed with many of the report's findings, noting in particular the lack of specialised victim accommodation and potential conflict of interest of protection and enforcement of immigration law with the formal identification mechanism being undertaken by An Garda Síochána. The ICI also reiterated its concerns that asylum seekers and EEA nationals fall outside the scope of the formal identification mechanism. ${ }^{409}$

In a statement responding to the report, the Department of Justice and Equality noted that the report would feed into ongoing work on the National Action Plan to Prevent and Combat Human Trafficking. The statement noted Ireland's cooperation with various organisations at international level, and work and structures at national level to address the ongoing challenge of combating human trafficking. ${ }^{410}$

\subsection{LEGAL DEVELOPMENTS}

\subsubsection{International developments}

Ireland ratified the International Labour Organization (ILO) Forced Labour Protocol $^{411}$ in February 2019. The Protocol reinforces the international legal framework for combating all forms of forced labour, including trafficking in

9 Immigrant Council of Ireland (25 June 2020) 'Major problems with how Ireland treats victims of trafficking identified in annual global report', Press Release. Available at: www.immigrantcouncil.ie.

410 Department of Justice and Equality (26 June 2020) 'Statement in relation to the Trafficking in Persons Report 2020'. Available at: www.justice.ie.

411 Protocol of 2014 to the Forced Labour Convention, $1930 . \quad$ See https://www.ilo.org/dyn/normlex/en/f?p=NORMLEXPUB:12100:0::NO::P12100_ILO_CODE:P029. 
persons. This initiative was led by the Department of Business, Enterprise and Innovation. ${ }^{412}$ Ireland was the 29th ILO Member State to ratify the Protocol. ${ }^{413}$

\subsubsection{National legislation}

\section{Criminal Justice (International Cooperation) Act 2019}

The Criminal Justice (Joint Investigation Teams) Act 2004 provides for the measures necessary to give effect to the EU Council Framework Decision 2002/465/JHA on joint investigation teams (JITs) ${ }^{414}$ and provides for the terms under which JITs can be established. The Criminal Justice (International Cooperation) Act 2019 made further provision to better facilitate the participation of members of An Garda Síochána in joint investigation teams. ${ }^{415}$ Section 6 of this Act amended section 51 of the Garda Síochána Act 2005 to enable the assignment of eligible members of An Garda Síochána for service outside of the State to carry out duties of a police character with an international organisation, to carry out liaison duties with Europol or, subject to the agreement of the Government, with a law enforcement agency of a state other than the State, or to act as members of a JIT in accordance with the 2002 EU Council Framework Decision on JITs, which may include JITs to combat trafficking in human beings. ${ }^{416}$

\section{Criminal Law (Sexual Offences) (Amendment) Act 2019 (No. 4 of 2019)} The Criminal Law (Sexual Offences) (Amendment) Act 2019 amends the Criminal Law (Sexual Offences) (Amendment) Act 2017 in relation to sentencing for subsequent offences and in relation to the schedule of offences pursuant to section 58 of the Criminal Law (Sexual Offences) Act 2017 (including sexual offences, sexual offences against children, child trafficking and pornography, soliciting or importuning a trafficked person for the purpose of prostitution). Section 4 of this Act inserts a new section 58 into the Criminal Law (Sexual Offences) Act 2017 in relation to sentencing for repeat sexual offenders. Under the new section 58, where an offender is convicted of a sexual offence listed in the Schedule to the Criminal Law (Sexual Offences) Act 2017, and is sentenced to imprisonment for a period of at least five years, and is subsequently - within a period of 10 years convicted of a further offence listed in the Schedule, the court shall, when imposing sentence for that offence, specify the minimum term of imprisonment to be served by the person. The minimum period of imprisonment shall be three-quarters of the maximum term of imprisonment prescribed by law in respect of such an offence

\footnotetext{
412 Department of Justice and Equality (17 December 2019) Response to Parliamentary Question 52557/19. Available at: www.justice.ie.

413 International Labour Organization (4 February 2019) 'Ireland joins efforts to combat forced labour. Ireland has ratified the Protocol of 2014 to the Forced Labour Convention, 1930, becoming the 29th ILO Member State to do so', News. Available at: https://www.ilo.org/global/standards/subjects-covered-by-international-labour-standards/forcedlabour/WCMS_668744/lang--en/index.htm.

414 Council Framework Decision of 13 June 2002 on JITs (2002/465/JHA).

415 Correspondence with Department of Justice and Equality, February 2020.

416 Additional analysis by EMN legal consultant, October 2020.
} 
and, where the maximum term is life imprisonment, the minimum shall be specified as a term of not less than 10 years. The court will have discretion in the application of the sentence if it is satisfied that this would be disproportionate in all the circumstances of the case. Section 5 of the 2019 Act inserts a Schedule into the Criminal Law (Sexual Offences) Act 2017 which lists the offences to which the provisions of the new section 58 of the 2017 Act will apply.

All the scheduled offences are sexual offences of a serious nature where the maximum penalty on conviction on indictment is five years' imprisonment or above, including offences under section 3 (child trafficking and taking, etc., child for sexual exploitation), section 4 (allowing child to be used for child pornography), section 4A (organising etc. child prostitution or production of child pornography), section 5 (producing, distributing, etc. child pornography), section 5A (participation of child in pornographic performance) and section 6 (possession of child pornography) of the Child Trafficking and Pornography Act 1998, and an offence under section 5 of the Criminal Law (Human Trafficking) Act 2008 (soliciting or importuning for purposes of prostitution of trafficked person). ${ }^{417}$ This Act was commenced via the Criminal Law (Sexual Offences) (Amendment) Act 2019 (Commencement) Order 2019 from 2 September 2019.

The Migrant Rights Centre Ireland ( $\mathrm{MRCl}$ ) made the following comment on this report regarding the Criminal Law (Sexual Offences) Act 2017 and human trafficking:

No conviction for trafficking has taken place in Ireland to date. This highlights that the introduction of the Criminal Law (Sexual Offences) Act 2017 has had little to no effect on anti-trafficking efforts. It remains to be seen what effect this amended act will have.

It is important acknowledge the intent behind the Criminal Law (Sexual Offences) Act 2017, was to ensure the safety of individuals who engage in sex work and tackle all forms of human trafficking prevalent in Ireland. $\mathrm{MRCl}$ believes that, following the implementation, this new criminalisation framework has created a repressive environment in which increased stigmatisation and exploitation of and violence against sex workers. For example, sex workers can't work together for safety for fear of contravening brothel-keeping provisions; two women were convicted under this provision in 2019 in a high profile case. ${ }^{418,419}$

417 Analysis provided by EMN legal consultant, October 2020.

418 Correspondence with $\mathrm{MRCl}$, November 2020.

419 The case referred to is described in Pollak, S. (10 June 2019) 'Jailing of sex workers keeping brothel shows law "not fit for purpose"', Irish Times. Available at: www.irishtimes.com. 


\subsection{NATIONAL DEVELOPMENTS}

\subsubsection{Labour exploitation in the Irish fishing industry}

As reported in previous years, new rules regarding the employment of non-EEA fishers in the Irish fishing fleet were agreed following media allegations of labour exploitation in 2015. A range of measures was agreed by a number of relevant Government Departments and agencies, including changes to the Atypical Worker Permission Scheme to provide permission for non-EEA workers to work in the Irish fishing fleet, and a Memorandum of Understanding on enforcement agreed between bodies having oversight in the industry. ${ }^{420} \mathrm{~A}$ total of 76 applications were approved under the Atypical Worker Permission Scheme in respect of non-EEA national workers in the Irish fishing fleet in 2019 (an additional 137 permissions were renewed). ${ }^{421}$

The WRC has been involved in the enforcement of employment rights and employment permits legislation in the whitefish sector since February 2016. In 2019, WRC inspections of the whitefish fleet continued. During Operation Proteus, which took place from 26 to 29 June 2019, WRC inspectors boarded 28 whitefish vessels at seven landing places across Ireland to inspect employment records, carry out compliance checks and interview employees.

Between April and June 2019, the WRC detected 256 contraventions of employment legislation. The breakdown is as follows:

- 26 per cent related to records;

- 19 per cent related to leave, public holiday and associated entitlements;

- 13 per cent related to failure to issue payslips;

- 16 per cent related to illegal workers;

- In 17 per cent of cases, owners were not co-operating and/or complying with an Inspector's requirement.

4 per cent of contraventions related to pay rates. ${ }^{422}$

In May 2018, the International Transport Workers' Federation (ITWF) wrote to the Minister for Justice and Equality seeking a moratorium on the issue or renewal of

\footnotetext{
420 Lead policy responsibility for the fishing sector resides with the Minister for Agriculture, Food and the Marine and the atypical worker permission is administered by the Department of Justice and Equality on behalf of that Department.

421 Correspondence with Atypical, Business and Start-Up Unit, Immigration Service Delivery, Department of Justice and Equality, February 2020.

422 Workplace Relations Commission (2 July 2019) 'Workplace Relations Commission concludes latest inspection of whitefish vessels', Press Release. Available at: www.workplacerelations.ie.
} 
atypical work permission to workers in the Irish fishing fleet and threatening High Court proceedings within 21 days. This arose from ITWF concerns about abuse of employment conditions and suspected trafficking for non-EEA fishermen in the Irish fishing fleet.

A mediation agreement was reached in April 2019. According to the Department of Justice and Equality:

Following an initial High Court ruling refusing injunctive relief to the plaintiff, the Department of Justice \& Equality together with various Departments and agencies, in an effort to avoid lengthy and costly litigation entered into a mediation process with the ITWF. The Court proceedings were subsequently struck out on 30 April 2019 following the conclusion of a successful mediation process. ${ }^{423}$

The main terms of the agreement between the parties were as follows:

- Every intended participant under the Scheme is to receive their contract of employment in their native language, as well as English. The contract will include clear wording regarding the fisher's entitlements to pay, working-hours, and rest periods. The letter of approval is also to be in the fisher's native language, as well as English, as appropriate.

- A link to a webpage explaining the fisher's rights as an employee and where the fisher can make complaints regarding any violation of these rights will be provided to participants in the Scheme in their letter of approval.

- As has previously been the case, the costs associated with applications under the Atypical Workers Scheme are not recoupable from the fisher's wages.

- No employment permission is granted to any non-EEA nationals to work in the State without a contract with a specific employer. Non-EEA fishers retain the right to transfer employment within the Scheme; any such transfer of employment can occur without the existing or previous employer's consent.

- Where the Department of Justice \& Equality becomes aware that a fisher has left their employment, for any reason, before the end of their twelve-month contract, a letter will issue to the non-EEA fisher requesting that they provide details of their new contract of employment under the Scheme to the Department of Justice \& Equality within 28 days.

- EU Directive $2017 / 159$ will be transposed into Irish law by the 15 th of November, regulating maximum hours of work, minimum hours of rest, and manning requirements aboard commercial fishing vessels. 
- The relevant bodies, i.e. the Workplace Relations Commission (WRC), the Marine Survey Office (MSO), and the Department of Justice and Equality, will liaise with each other on the enforcement of S.I. 709 of 2003 (relating to the hours of work and rest on board fishing vessels). ${ }^{424}$

The WRC also upheld several complaints made by non-EEA fishermen against their employers in relation to payment of wages and other employment rights. For example, in January 2019, an award of almost $€ 40,000$ was made in relation to underpayment of wages, excessive working hours and breaches in relation to rest breaks, leave and public holidays. ${ }^{425}$ This award was welcomed by the ITWF. ${ }^{426}$

The $\mathrm{MRCl}$ has noted that it raised concerns regarding some conditions of the atypical working scheme applicable to fishers in December 2019. These concerns related to the renewal of the atypical permit, where late submission of applications by employers was leading to some fishers becoming undocumented through no fault of their own; the 28-day notice period for a fisher to provide a new contract of employment when the fisher has left employment before the end of the 12month contract; and the passport validity requirement of 12 months for renewal of the atypical permit. $\mathrm{MRCl}$ was of the view that passport validity requirements applicable to employment permits should also be applied to the atypical scheme. $^{427}$

$\mathrm{MRCl}$ also commented that Ireland missed the transposition deadline of 15 November 2019 for Council Directive 2017/159 regarding the implementation of the Work in Fishing Convention, ${ }^{428}$ referring to a question put to the European Parliament on 23 January 2020 which asserts that 'the regulations ${ }^{429}$ transposing this directive were not introduced until 19 December 2019 and were unsatisfactory'. ${ }^{430}$ The European Commission in response on 26 March 2020 noted that, as Ireland had not notified any transposition measures, a letter of formal notice was sent to Ireland in January 2020. The Commission said: 'Only after the notification of these transposition measures will the Commission be in a position

424 Workplace Relations Commission (2 July 2019) 'Workplace Relations Commission concludes latest inspection of whitefish vessels', Press Release. Available at: www.workplacerelations.ie.

425 A crew member $v$ A fishing boat owner/operator, Adjudication 00012854, 3 January 2019. Available at: https://www.workplacerelations.ie/en/search/?decisions.

426 Deegan, G. (17 January 2019) 'Fishing crew member working on "floating factory" awarded €40,000 compensation by WRC', Irish Examiner. Available at: www.irishexaminer.com.

427 Correspondence with Migrant Rights Centre Ireland, November 2020.

428 Ibid.

429 The question further refers to S.I. 672 of 2019 European Union (International Labour Organization Work in Fishing Convention) (Working Hours) Regulations 2019.

430 European Parliament (23 January 2020) Question for written answer E-000368/2020 to the Commission Rule 138 Clare Daly (GUE/NGL) Subject: Irish fisheries and the implementation of the Working Time Directive. Available at: https://www.europarl.europa.eu/doceo/document/E-9-2020-000368_EN.html. 
to assess whether they ensure a complete and correct transposition of Directive 2017/159. ${ }^{431}$

\subsubsection{Policy developments at the national level}

\section{Research on victim perspectives of trafficking for the purposes of sexual exploitation}

Agreement on the scope of a research project was reached with Maynooth University in January 2019 with a view to providing funding for a research project which will examine victim perspectives of trafficking for the purposes of sexual exploitation in Ireland, their view and understanding of the judicial system and Criminal Law (Sexual Offences) Act 2017 and to map the legal, policy and theoretical context of sex trafficking in Ireland. This project is expected to report in 2020. This research follows Maynooth University's study into labour exploitation in Ireland, which was published in British Journal of Criminology in August $2018 .{ }^{432}$

\section{Accommodation for victims of trafficking}

Throughout 2019, the Department of Justice and Equality engaged with nongovernmental organisations (NGOs) to examine an NGO-led solution to the issue of accommodation for victims of trafficking, ${ }^{433}$ in particular for female victims of sexual exploitation, a particularly vulnerable group. Agreement in principle has been reached with an NGO active in the housing sector, which has already carried out useful work with the Department of Justice and Equality in moving successful international protection applicants into long-term accommodation. Another key requirement is for the service to include a practical process for moving victims of human trafficking to long-term independent accommodation within a time frame that will allow the facility to maintain the capacity to admit new clients urgently. The Department of Justice and Equality expects to be in a position to finalise an agreement with the NGO concerned in the near future. ${ }^{434}$

\section{National Rapporteur or Equivalent Mechanisms on trafficking in human beings \\ Ireland announced that the Irish Human Rights and Equality Commission would be designated as Ireland's national rapporteur at the meeting of the EU Network of National Rapporteurs or Equivalent Mechanisms (NREMs) on Trafficking in Human Beings on 4 and 5 December 2019. According to the Department of Justice and Equality: 'the NREMs' tasks are essential, as they include the carrying out of the}

\footnotetext{
431 European Parliament (26 March 2020) Answer given by Mr Schmit on behalf of the European Commission Question reference: E-000368/2020. Available at: https://www.europarl.europa.eu/doceo/document/E-9-2020-000368ASW_EN.html.

432 Correspondence with Department of Justice and Equality, February 2020.

433 Department of Justice and Equality (10 December 2019) Response to Parliamentary Question 51595/19. Available at: www.justice.ie.

434 Correspondence with Department of Justice and Equality, February 2020.
} 
assessments of trends in trafficking in human beings, the measuring of results of anti-trafficking actions, including the gathering of statistics in close co-operation with relevant NGOs active in this field, and reporting'. ${ }^{435}$ The Minister for Justice signed regulations to make the Irish Human Rights and Equality Commission (IHREC) Ireland's national rapporteur on 22 October 2020.436

\subsection{FUNDING}

The Department of Justice and Equality signed an agreement in June 2019 to support the Sexual Exploitation Research Project (SERP), which is under the School of Social Policy, Social Work and Social Justice, University College Dublin, with funding secured under the Dormant Accounts Plan 2018. The agreement runs for a year. The project aims to provide empirical data on the experience of women in the commercial sex trade and the response of the criminal justice system in the context of the Criminal Law (Sexual Offences) Act 2017. This project draws significantly on information held by the Health Service Executive (HSE) Anti Human Trafficking Team and work already done under an earlier joint HSE/Department of Justice and Equality research project during $2018 .{ }^{437}$

Also, under the Dormant Accounts Action Plan 2018, the Department of Justice and Equality secured funding to support the GOSHH project (Gender, Orientation, Sexual Health and HIV), a charity based in Limerick City. The research is being carried out by a member of GOSHH and a researcher from University of Limerick. The project aims to explore the current levels of awareness and 'know-how' about the criminalisation of purchasing sex legislation among survival sex workers. It also aims to design an evidence-based ethical approach to research and working with survival sex workers. The agreement for this project was signed in May 2019 and runs for a year.

Funding was also made available to NGO partners who work with at-risk sectors of the economy and with vulnerable people. Funding is available on an annual basis to organisations that:

- operate a structured process for assessment, preliminary identification of potential victims and referral to the National Referral Mechanism

- assist individuals from exiting trafficking situations

- provide support to victims to access compensation, housing, health, and crisis supports

Ibid.

Correspondence with Department of Justice and Equality, October 2020.

Ibid. 
- carry out case management and supervision, including reporting to the Department of Justice and Equality on a scheduled basis

- deliver other relevant activities.

In 2019, $€ 350,000$ was allocated to Ruhama, an NGO that represents the interests of women who work in the sex industry and associated organised prostitution in Ireland, and $€ 84,500$ was allocated to the MRCI. ${ }^{438}$

\subsection{INTERAGENCY AND INTERNATIONAL CO-OPERATION}

\subsubsection{Awareness-raising}

In 2019, Ireland participated, with 23 other European states, in the EUCPN (EU Crime Prevention Network) and Europol awareness-raising campaign on the issue of Trafficking in Human Beings (THB). The campaign was designed to target victims and potential victims of human trafficking, who are not often addressed.

The main goals were to step up the fight against this crime by informing:

- (potential) victims that they could be or become a victim of THB

- victims of THB where they can find help, protection and information

- victims of THB that they have EU-wide rights.

On the national level, the Department of Justice and Equality recruited support from NGOs, Government Departments and other organisations and offices to contribute to this effort in putting up posters and participating on social media on 17 and 18 October 2019 to raise awareness of this issue. Posters were displayed in train stations, bus stations, a number of government offices (Irish Naturalisation and Immigration Service Registration Office, International Protection Office and the Department of Business, Enterprise and Innovation); by the Border Management Unit at Dublin Airport; and by the Legal Aid Board in public offices. A number of other government organisations and NGOs also supported the campaign on social media. ${ }^{439}$

The HSE and the Royal College of Surgeons in Ireland (RCSI) partnered in an initiative with the International Council of Nurses (ICN) to produce a booklet for the worldwide community of nurses advising on human trafficking, including how

Ibid.

Department of Justice and Equality (17 October 2019) ‘EU Anti-Human Trafficking Day marked with commemoration of the legacy of Frederick Douglass. Minister Stanton calls on public to know the signs of human trafficking. Europewide prevention campaign to highlight trafficking across 24 European states', Press Release. Available at: www.justice.ie. 
to recognise the signs of human trafficking, medical indicators that should raise concern, and appropriate further action. The booklet will be published initially in English, Spanish and French. It was launched at the ICN conference in Singapore in July 2019. ${ }^{440}$

To mark EU anti-human trafficking day on 18 October 2019, a special event took place in Cork to raise awareness of human trafficking via a commemoration of the visit of Frederick Douglass, an escaped slave and anti-slavery campaigner, to Cork in 1845. The event was a collaboration between the Department of Justice and Equality and MECPATHS, an NGO collaborating with the hospitality sector in Ireland to raise awareness around child trafficking and empower hotel management and staff to identify vulnerable children in order to help combat this crime. ${ }^{441}$

The $\mathrm{ICl}$ established as lead partner the Asylum, Migration and Integration Fund (AMIF)-funded ASSIST ${ }^{442}$ project with transnational partners, ${ }^{443}$ which was launched in March 2019. The project focuses on the integration of trafficked migrant women recovering from sexual exploitation. The aim of the project is to provide a number of trafficked migrant women with legal advice, information and support in accessing material assistance (both social and financial). ${ }^{444}$ In addition, priorities of the project for $\mathbf{2 0 1 9}$ were to map services in the participating states in order to identify gaps in service delivery, and to establish a peer support programme, to train survivors as peer mentors for newly identified victims of trafficking. ${ }^{445}$

\subsubsection{Co-operation by police and other operational authorities}

A number of operations with a cross-border dimension are undertaken by An Garda Síochána, involving participation by the Police Service of Northern Ireland (PSNI). The relevant investigations involve both police organisations targeting organised crime groups (OCGs) that are suspected to be involved in the organisation of prostitution.

According to An Garda Síochána, recent joint co-operation and relevant 'Days of Action' relating to suspected prostitution have revealed strong links with Northern

\footnotetext{
440 Department of Justice and Equality (4 July 2019) 'Irish Government welcomes launch of programme to raise awareness of human trafficking among worldwide community of nurses', Press Release. Available at: www.justice.ie.

441 Department of Justice and Equality (17 October 2019) 'EU Anti-Human Trafficking Day marked with commemoration of the legacy of Frederick Douglass. Minister Stanton calls on public to know the signs of human trafficking. Europewide prevention campaign to highlight trafficking across 24 European states', Press Release. Available at: www.justice.ie. ASSIST: Gender Specific Legal Assistance and Integration Support for Third Country National Female Victims of Trafficking for Sexual Exploitation.

443 SOLWODI Germany, JustRight Scotland, BeFree Italy, SURT Spain and the European Network of Migrant Women.

444 Immigrant Council of Ireland (18 March 2019) 'Launching new trans-European anti-trafficking project to assist trafficked migrant women', News. Available at: www.immigrantcouncil.ie.

445 Immigrant Council of Ireland (4 June 2020) Impact Report 2019, p. 15. Available at: www.immigrantcouncil.ie.
} 
Ireland in relation to prostitution being engaged in on both sides of the border. Evidence gathered indicates that relevant OCGs operating on the island of Ireland are using points of entry in the South of Ireland as a means of trafficking potential victims of human-trafficking into Ireland, before they travel to Northern Ireland where their exploitation continues. ${ }^{446}$

In June 2019, the Border Management Unit (BMU) of the Department of Justice and Equality ran a week of action at Dublin Airport against child trafficking as part of an EU-wide initiative by Europol. ${ }^{477}$ Immigration Control Officers carried out intensified checks at passport control. While safeguarding children is an ongoing priority at passport control, Immigration Control Officers were trained in how to pay particular attention to minors who were accompanied by adults other than immediate family members. Staff were also requested to disseminate Irish Naturalisation and Immigration Service policy on travelling with minors to all who presented with minors, including parents/legal guardians, to fulfil the awareness part of the week.

The Department of Justice and Equality's Blue Blindfold posters were displayed in all booths as well as Ruhama posters; leaflets were made available for staff to distribute to individuals who were immigrating. The Dublin Airport Authority ran the Blue Blindfold videos in numerous locations throughout the terminals. Staff were issued with instructions by email and briefings were provided to supervisors during the week to assist them should any safeguarding issues arise. The first briefing of the week was attended by BMU management and supervisors as well as staff from the Garda National Immigration Bureau (GNIB). In total, 114 minors were encountered that met the specification. Of the 114 encountered, no followup was necessary in $\mathbf{5 2}$ of the cases as there were no safeguarding concerns. In 61 cases, either documentation was provided to satisfy the officer that the minor was safe or phone calls were made to verify the minor's story and the officer was satisfied that they were safe. One case required the assistance of the GNIB and Tusla, the Child and Family Agency. People travelling through the airport were reminded that the safeguarding of children and anti-trafficking of human beings is a key priority for the BMU. ${ }^{448}$ 



\section{REFERENCES}

An Garda Síochána (5 March 2019). 'Multi Agency Day of Action to Target Abuses of Immigration and PSV Legislation on the $5 / 3 / 19^{\prime}$, Press Release. Available at: www.garda.ie

An Garda Síochána (October 2019). An Garda Síochána Diversity and Integration Strategy 2019-2021. Available at: www.garda.ie

An Garda Síochána (December 2019). Monthly Report to the Policing Authority - In accordance with Section 41A of the Garda Síochána Act 2005 (as amended). Available at: www.garda.ie

Children's Rights Alliance (March 2020). Report Card 2020. Available at: www.childrensrights.ie

Committee on the Elimination of Racial Discrimination (3 October 2018). Combined fifth to ninth periodic reports submitted by Ireland under article 9 of the Convention, due in 2014 CERD/C/IRL/5-9, advance unedited version. Available at: www.justice.ie

Committee on the Elimination of Racial Discrimination (12 December 2019). Concluding Observations on the combined fifth to ninth reports of Ireland CERD C/IRL/Co/5-9, advance unedited version. Available at: https://tbinternet.ohchr.org

Courts Service of Ireland (July 2020). Courts Service Annual Report 2019. Available at: www.courts.ie

Deegan, G. (17 January 2019). 'Fishing crew member working on "floating factory" awarded $€ 40,000$ compensation by $W_{R C}$, Irish Examiner. Available at: www.irishexaminer.com

Department of Business, Enterprise and Innovation (6 March 2019). 'Ministers Humphreys and Flanagan announce change to immigration arrangements for spouses and partners of Critical Skills Employment Permit Holders and Researchers under a Hosting Agreement', Latest updates and developments in respect to Employment Permits. Available at: www.dbei.gov.ie

Department of Business, Enterprise and Innovation (8 November 2019). 'Information note on the General Scheme of an Employment Permits (Consolidation and Amendment) Bill'. Available at: www.dbei.gov.ie

Department of Business, Enterprise and Innovation (20 November 2019). 'Early notice of changes to the operation of the Employment Permits system'. Available at: www.dbei.gov.ie

Department of Business, Enterprise and Innovation (3 December 2019). 'Public Consultation on the General Scheme of an Employment Permits (Consolidation and Amendment) Bill', Press Release. Available at: www.dbei.gov.ie

Department of Business, Enterprise and Innovation (3 January 2020). Employment Permits by Nationality 2019. Available at: www.dbei.gov.ie 
Department of Education and Skills (October 2016). International Education Strategy for Ireland 2016-2020. Available at: www.education.ie

Department of Education and Skills (4 June 2019). 'Ministers announce Student Support Scheme for Asylum Seekers to continue for coming year', Press Release. Available at: www.education.ie

Department of Education and Skills (11 July 2019). 'Qualifications and Quality Assurance (Education and Training) (Amendment) Bill 2018 Passes both Houses of the Oireachtas', Press Release. Available at: www.education.ie

Department of Foreign Affairs and Trade (28 February 2019). “'A Better World”, Ireland's New Policy for International Development', Press Release. Available at: www.dfa.ie

Department of Foreign Affairs and Trade (14 May 2019). 'Minister of State Cannon launches programme of community-based events to celebrate Africa Day', Press Release. Available at: www.dfa.ie

Department of Foreign Affairs and Trade (10 June 2019). 'Tánaiste launches new strategy for Ireland's partnership with Small Island Developing States', Press Release. Available at: www.dfa.ie

Department of Foreign Affairs and Trade (27 November 2019). 'Launch of the Government's New Africa Strategy: Global Ireland: Ireland's Strategy for Africa', Press Release. Available at: www.dfa.ie

Department of Justice and Equality (5 November 2018). 'Immigrant Investor Programme Terms of Reference for External Review' Available at: www.inis.gov.ie

Department of Justice and Equality (17 January 2019) Speech by Minister for Justice and Equality, Charlie Flanagan TD, Irish Nationality and Citizenship (Restoration of Birthright Citizenship) Bill 2017. Available at: www.justice.ie

Department of Justice and Equality (27 February 2019). 'Withdrawal of the United Kingdom from the European Union (Consequential Provisions) Bill 2019 Second Stage Speech by Charlie Flanagan TD, Minister for Justice and Equality, Dáil Éireann, 27 February 2019' Available at: www.justice.ie

Department of Justice and Equality (6 March 2019). 'Important Notice: Update to the INIS Non-EEA Family Reunification Policy Document'. Available at: www.inis.gov.ie

Department of Justice and Equality (6 March 2019). 'Minister Stanton calls on communities to sponsor a refugee family as he launches pilot Community Sponsorship Ireland initiative', Press Release. Available at: www.justice.ie

Department of Justice and Equality (3 April 2019). 'Minister Stanton hosts Public and Stakeholder Consultation for the International Decade for People of African Descent (2015-2024)', Press Release. Available at: www.justice.ie

Department of Justice and Equality (12 April 2019). 'Minister Flanagan announces abolition of re-entry visa system', Press Release. Available at: www.inis.gov.ie

Department of Justice and Equality (updated 30 May 2019). 'Abolition of adult re-entry visas', available at: www.inis.gov.ie 
Department of Justice and Equality (1 June 2019). 'Minister Flanagan officially opens new eGates in Dublin Airport', Press Release. Available at: www.inis.gov.ie

Department of Justice and Equality (22 June 2019). 'Minister Flanagan announces new 5 year Multi-Entry Visa option for Chinese tourists', Press Release. Available at: www.inis.gov.ie

Department of Justice and Equality (28 June 2019). 'Minister Stanton announces new AntiRacism Committee', Press Release. Available at: www.justice.ie

Department of Justice and Equality (4 July 2019). 'Irish Government welcomes launch of programme to raise awareness of human trafficking among worldwide community of nurses', Press Release. Available at: www.justice.ie

Department of Justice and Equality (11 July 2019). 'Ministers announce $€ 526,000$ Community Integration Fund 2019', Press Release. Available at: www.justice.ie

Department of Justice and Equality (29 July 2019). 'Minister Flanagan announces new immigration registration renewal system for 3rd level students', Press Release. Available at: www.inis.gov.ie

Department of Justice and Equality (29 July 2019). 'Updates and announcements 2019: Updated Statement from INIS on the recent judgment in the High Court citizenship case'. Available at: http://inis.gov.ie/en/INIS/Pages/2019

Department of Justice and Equality (15 August 2019). 'Ministers Flanagan and Stanton welcome publication of the Spending Review on Direct Provision', Press Release. Available at: www.justice.ie

Department of Justice and Equality (19 August 2019). 'New preclearance process to be introduced to help non-EEA de facto partners of Irish citizens to live and work in Ireland', Press Release. Available at: www.inis.gov.ie

Department of Justice and Equality (1 October 2019). 'Statement from the Department of Justice and Equality regarding Oughterard'. Available at: www.justice.ie

Department of Justice and Equality (7 October 2019). 'Funding for Gender equality and migrant integration announced by Minister Flanagan and Minister Stanton', Press Release. Available at: www.justice.ie

Department of Justice and Equality (10 October 2019). 'Hate Speech Public Consultation'. Available at: www.justice.ie

Department of Justice and Equality (11 October 2019). 'Minister Stanton welcomes the announcement of the GRSI "International Award" to Ireland for the Community Sponsorship Initiative (CSI)', Press Release. Available at: www.justice.ie

Department of Justice and Equality (17 October 2019). 'EU Anti-Human Trafficking Day marked with commemoration of the legacy of Frederick Douglass. Minister Stanton calls on public to know the signs of human trafficking. Europe-wide prevention campaign to highlight trafficking across 24 European states', Press Release. Available at: www.justice.ie 
Department of Justice and Equality (8 November 2019). 'Speech by Secretary General Aidan O'Driscoll at the Justice Committee regarding the Department of Justice and Equality's Transformation programme.' Available at: www.justice.ie

Department of Justice and Equality (15 November 2019). 'Minister Stanton Officially Launches Refugee Community Sponsorship Ireland', Press Release. Available at: www.justice.ie

Department of Justice and Equality (22 November 2019). 'Statement on tenders for accommodation centres for international protection applicants', Press Release. Available at: www.justice.ie

Department of Justice and Equality (27 November 2019). 'Statement by Minister for Justice and Equality on Provision of Accommodation and Ancillary Services to applicants for International Protection, Seanad Éireann'. Available at: www.justice.ie

Department of Justice and Equality (2 December 2019). 'Minister Stanton delivers Ireland's National Statement to CERD in Geneva', Press Release. Available at: www.justice.ie

Department of Justice and Equality (2 December 2019). 'Doctors providing locum service in the primary care sector (General Practice)'. Available at: www.inis.gov.ie

Department of Justice and Equality (2 December 2019). 'Opening Statement of Ireland at the Committee on the Elimination of Racial Discrimination'. Available at: www.justice.ie

Department of Justice and Equality (4 December 2019). 'Enforced Removal of 23 People with Deportation Orders' Press Release. Available at: www.justice.ie

Department of Justice and Equality (17 December 2019). 'Ireland commits to a new Refugee Protection Programme', Press Release. Available at: www.justice.ie

Department of Justice and Equality (30 December 2019). 'Minister Flanagan welcomes Syrian refugee families at Mosney', Press Release. Available at: www.justice.ie

Department of Justice and Equality (31 January 2020). 'Information Notice for non-EEA family members of British citizens who are residing in Ireland'. Available at: www.inis.gov.ie

Department of Justice and Equality (26 June 2020). 'Statement in relation to the Trafficking in Persons Report 2020'. Available at: www.justice.ie

Department of Justice and Equality and Department of Education and Skills (2019). Department Of Justice and Equality Irish Naturalisation and Immigration Service (INIS) Interim List of Eligible Programmes for Student Immigration Permission Arrangements Applying to Foundation Programmes from 9 September 2019', Information Note. Available at: www.inis.gov.ie

Economic and Social Research Institute (26 June 2019). 'Generally low levels of residential segregation of migrants in Ireland', Press Release. Available at: www.esri.ie

Fahey E., F. McGinnity and E. Quinn (March 2019). Data for monitoring integration: gaps, challenges and opportunities. Dublin: The Economic and Social Research Institute. Available at: www.esri.ie 
Fahey, E., H. Russell, F. McGinnity and R. Grotti (June 2019). Diverse neighbourhoods: an analysis of the residential distribution of immigrants in Ireland, Dublin: Economic and Social Research Institute. Available at: www.esri.ie

Government of Ireland (February 2019). A Better World. Available at: www.dfa.ie

Government of Ireland (June 2019). Strategy for Partnership with Small Island Developing States. Available at: www.dfa.ie

Government of Ireland (November 2019). Global Ireland - Ireland's Strategy for Africa to 2025. Available at: www.dfa.ie

Government of Ireland (28 December 2019). 'Ministers Flanagan and Stanton announce establishment of Expert Group on Direct Provision', Press Release. Available at: www.merrionstreet.ie

Government of Ireland (September 2020). Report of the Advisory Group on the Provision of Support including Accommodation to Persons in the International Protection Process. Available at: www.gov.ie

Groarke, S. and P. Brazil (2020). National Statuses granted for protection reasons in Ireland. Available at www.emn.ie and www.esri.ie

Groarke, S. and C. Durst (May 2019) Attracting and retaining international higher education students: Ireland. Available at: www.emn.ie and www.esri.ie

Irish Human Rights and Equality Commission (October 2019). Ireland and the Convention on the Elimination of Racial Discrimination Submission to the United Nations Committee on the Elimination of Racial Discrimination on Ireland's Combined 5th to 9th Report, pp. 10-11. Available at: www.ihrec.ie

Immigrant Council of Ireland (18 March 2019). 'Launching new trans-European antitrafficking project to assist trafficked migrant women'. Available at: www.immigrantcouncil.ie

Immigrant Council of Ireland (June 2020). Impact Report 2019. Available at: www.immigrantcouncil.ie

Immigrant Council of Ireland (25 June 2020). 'Major problems with how Ireland treats victims of trafficking identified in annual global report', Press Release. Available at: www.immigrantcouncil.ie

Immigrant Council of Ireland (28 June 2019). 'Progress report into Ireland's integration strategy highlights gaps', Press Release. Available at: www.immigrantcouncil.ie

Immigrant Council of Ireland (29 July 2020). 'Huge cracks in immigration system magnified during Covid-19', Press Release. Available at: www.immigrantcouncil.ie

International Labour Organization (4 February 2019). 'Ireland joins efforts to combat forced labour. Ireland has ratified the Protocol of 2014 to the Forced Labour Convention, 1930, becoming the 29th ILO Member State to do so'. Available at: https://www.ilo.org/global/standards/subjects-covered-by-international-labourstandards/forced-labour/WCMS_668744/lang--en/index.htm 
International Protection Appeals Tribunal (March 2020). International Protection Appeals Tribunal Annual Report 2019. Available at: www. protectionappeals.ie

Irish Migrant and Refugee Coalition (13 September 2019). 'Irish Refugee and Migrant Coalition call on Irish Government to increase commitment to refugee resettlement'. Available at: www.nasc.org

Irish Network Against Racism (18 March 2020). 'Racism figures climb in the context of political hate speech', Media Release. Available at: www.inar.ie

Irish Network Against Racism (13 December 2019). 'The CERD Committee findings on Ireland published', Press Release. Available at: www.inar.ie

Irish Refugee Council (6 March 2019). 'Regional support organisations welcome official launch by Minister Stanton of Community Sponsorship', Press Release. Available at: www.irishrefugeecouncil.ie

Irish Refugee Council (26 May 2019). 'Refugee organisations highlight absence of vulnerability assessment in Irish asylum procedure', Press Release. Available at: www.irishrefugeecouncil.ie

Irish Refugee Council (5 June 2019). 'Financial supports introduced for Leaving Certificate students who are three years in the asylum process', Press Release. Available at: www.irishrefugeecouncil.ie

Irish Refugee Council (12 July 2019). The Reception Conditions Directive - one year on. Available at: www.irishrefugeecouncil.ie

Irish Refugee Council (April 2020). 'Irish Refugee Council welcome report: the Ombudsman \& Direct Provision: Update for 2019', Press Release. Available at: www.irishrefugeecouncil.ie

Irish Refugee Council (June 2020). AIDA Database Update Available at: www.asylumineurope.org

Joint Committee on Justice and Equality (July 2019). Report on Scrutiny of the International Protection (Family Reunification) (Amendment) Bill 2017 [PMB] July 2019. Available at: www.oireachtas.ie

Joint Committee on Justice and Equality (December 2019). Report on direct provision and the international protection process. Available at: www.oireachtas.ie

Joint Committee on Justice and Equality (12 December 2019). 'Joint Committee on Justice and Equality report finds Direct Provision "not fit for purpose" and calls for fundamental reform of "flawed" international protection application process', Press Release. Available on www.oireachtas.ie

Joint report from the negotiators of the European Union and the United Kingdom Government on progress during phase 1 of negotiations under Article 50 TEU on the United Kingdom's orderly withdrawal from the European Union, 8 December 2017, paragraph 54. Available at: https://ec.europa.eu

Lally, C., J. Horgan-Jones and H. McGee (21 November 2019). 'Migrants found on Rosslarebound ferry "thought they were going to UK"', Irish Times. Available at: www.irishtimes.com 
McNamara, F. and E. Quinn (January 2020). Migratory pathways to Ireland for start-ups and innovative entrepreneurs. Available at: www.emn.ie and www.esri.ie

Melia, J./IOM Ireland (2020). Responding to sexual and gender-based violence-guidance for International Protection Accommodation Centre managers and personnel. Available at: www.iomireland.ie

Migrant Rights Centre of Ireland (2018) 'MRCl submission to consultation on proposed guiding principles to frame the State's economic migration policy'. Available at: www.mrci.ie

Migrant Rights Centre of Ireland (3 July 2019). 'New survey gives unprecedented picture of undocumented children and young people in Ireland', Press Release. Available at: www.mrci.ie

Nasc, the Migrant and Refugee Rights Centre (n.d.). 'Nasc welcomes the launch and publication of the National Standards for Direct Provision', Press Release. Available at: www.nasc.org

O Fatharta, C. (22 November 2019). “"Asylum seekers will continue to risk their lives”: Irish Refugee Council call for "real" action', Irish Examiner. Available at: www.irishexaminer.com

Office of the Ombudsman (April 2020). The Ombudsman \& Direct Provision: Update for 2019. A commentary by the Ombudsman. Available at: www.ombudsman.ie

Office of the Ombudsman for Children (September 2020). Annual Report 2019. Available at: www.oco.ie

O'Neill, K. (25 October 2019). 'Legal migration "could prevent further tragedy"', Irish Examiner. Available at: www.irishexaminer.com

Pollak, S. (10 June 2019). 'Jailing of sex workers keeping brothel shows law "not fit for purpose"', Irish Times. Available at: www.irishtimes.com

RTÉ (22 November 2019). 'Security must be tightened at Irish ports, says Flanagan'. Available at: www.rte.ie

Sheridan, A. (2017). Annual Report on Migration and Asylum 2016: Ireland. Available at: www.emn.ie and www.esri.ie

Sheridan, A. (November 2019). Annual Report on Migration and Asylum 2018: Ireland. Available at: www.emn.ie and www.esri.ie

Tusla (June 2019). Tusla Annual Report 2019. Available at: www.tusla.ie

United Nations High Commissioner for Refugees (11 July 2019). 'UNHCR chief commends Irish solidarity with refugees and asks for further efforts to support those forced to flee', Press Release. Available at: www.unhcr.org

United Nations High Commissioner for Refugees (15 November 2019). 'Ireland strengthens response to refugee protection with the formal launch of Community Sponsorship programme', Press Release. Available at: www.unhcr.org 
United Nations High Commissioner for Refugees, Ireland (25 November 2019). 'Comments. Committee on the Elimination of Racial Discrimination 100th Session 25 November-13 December 2019 Ireland'. Available at: www.unhcr.org

United Nations High Commissioner for Refugees (12 December 2019). 'UNHCR welcomes Oireachtas Committee report on Direct Provision and the International Protection Process', Press Release. Available at: www.unhcr.org

United Nations High Commissioner for Refugees (17 December 2019). 'UNHCR welcomes Ireland's decision to welcome 2,900 refugees over the next 4 years', Press Release. Available at: www.unhcr.org

United Nations High Commissioner for Refugees (18 December 2019). 'Ireland pledges support for refugees at Global Refugee Forum', Press Release. Available at: www.unhcr.org

US State Department (2020). Trafficking in Persons Report, 20th edition, p. 270. Available at: https://state.gov

Workplace Relations Commission (2 July 2019). 'Workplace Relations Commission concludes latest inspection of whitefish vessels', Press Release. Available at: www.workplacerelations.ie 
